Prepared in cooperation with the city of Wichita, Kansas

\title{
Continuous Real-Time Water-Quality Monitoring and Regression Analysis to Compute Constituent Concentrations and Loads in the North Fork Ninnescah River Upstream from Cheney Reservoir, South-Central Kansas, 1999-2012
}

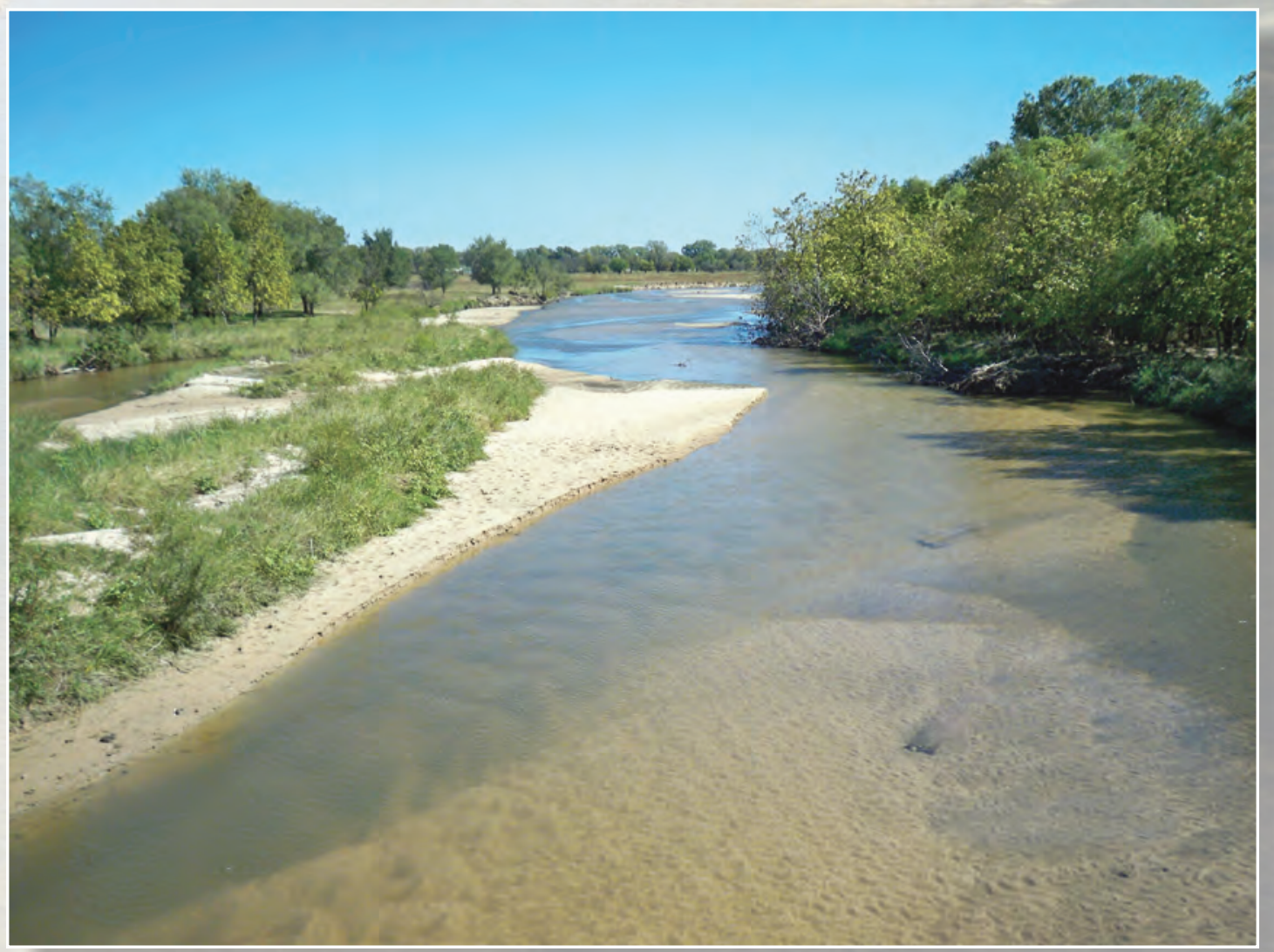

Scientific Investigations Report 2013-5071 
Cover photograph. Downstream view from the bridge, North Fork Ninnescah River above Cheney Reservoir, Kansas, 2010. Photograph by Barbara Dague, U.S. Geological Survey.

Back cover photograph. Upstream view from the bridge, North Fork Ninnescah River above Cheney Reservoir, Kansas, 2007. Photograph by Trudy Bennett, U.S. Geological Survey. 


\section{Continuous Real-Time Water-Quality Monitoring and Regression Analysis to Compute Constituent Concentrations and Loads in the North Fork Ninnescah River Upstream from Cheney Reservoir, South- Central Kansas, 1999-2012}

By Mandy L. Stone, Jennifer L. Graham, and Jackline W. Gatotho

Prepared in cooperation with the city of Wichita, Kansas

Scientific Investigations Report 2013-5071 


\title{
U.S. Department of the Interior SALLY JEWELL, Secretary
}

\section{U.S. Geological Survey Suzette M. Kimball, Acting Director}

\author{
U.S. Geological Survey, Reston, Virginia: 2013
}

For more information on the USGS - the Federal source for science about the Earth, its natural and living resources, natural hazards, and the environment, visit http://www.usgs.gov or call 1-888-ASK-USGS.

For an overview of USGS information products, including maps, imagery, and publications, visit http://www.usgs.gov/pubprod

To order this and other USGS information products, visit http://store.usgs.gov

Any use of trade, firm, or product names is for descriptive purposes only and does not imply endorsement by the U.S. Government.

Although this information product, for the most part, is in the public domain, it also may contain copyrighted materials as noted in the text. Permission to reproduce copyrighted items must be secured from the copyright owner.

Suggested citation:

Stone, M.L., Graham, J.L., and Gatotho, J.W., 2013, Continuous real-time water-quality monitoring and regression analysis to compute constituent concentrations and loads in the North Fork Ninnescah River upstream from Cheney Reservoir, south-central Kansas, 1999-2012: U.S. Geological Survey Scientific Investigations Report 2013-5071, 44 p. 


\section{Acknowledgments}

The authors appreciate the assistance of Howard Miller and Lisa French of Cheney Lake Watershed, Inc. for providing best management practices data. Vernon Strasser and laboratory staff of the Wichita Municipal Water and Wastewater Quality Laboratory provided laboratory analyses.

The authors thank Jennifer Lanning-Rush and Spoorthi Tammareddi of the U.S. Geological Survey (USGS) Kansas Water Science Center (KSWSC) for creating maps and assistance with data analysis, respectively. Trudy Bennett and USGS Wichita Field Office employees collected waterquality samples that were used to develop this report. Teresa Rasmussen of the USGS KSWSC and Nathan Schaepe of the USGS Nebraska Water Science Center provided helpful reviews that improved earlier drafts of this report. 


\section{Contents}

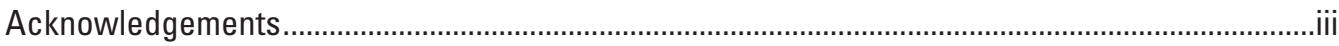

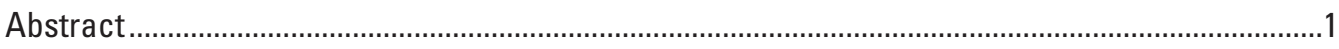

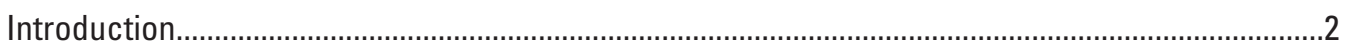

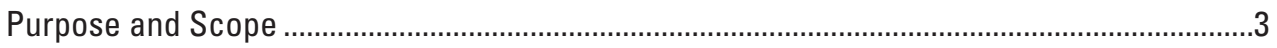

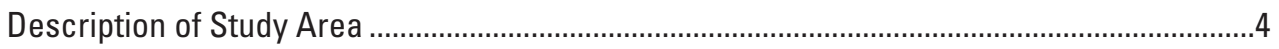

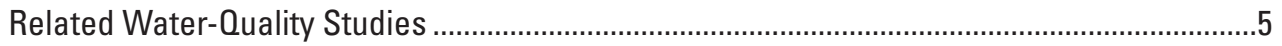

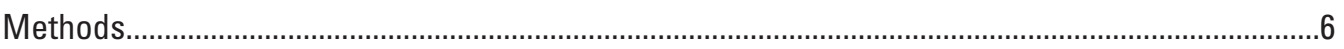

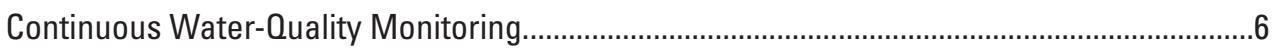

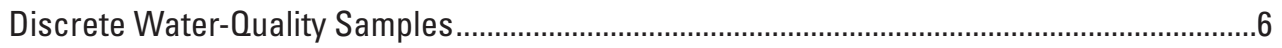

Quality Assurance and Quality Control .......................................................................................

Development of Regression Models to Compute Constituent Concentrations.........................8

Calculation of Annual Streamflow-Separation Points and Constituent Loads and Yields .......8

Calculation of Conversion Factors for Turbidity Sensors ..........................................................

Results of Continuously Monitored Variables ................................................................................

Results of Regression Analysis for Selected Constituents.......................................................11

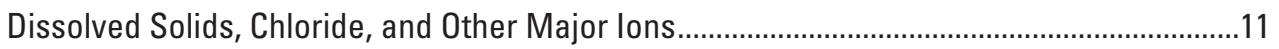

Total Suspended Solids and Sediment................................................................................

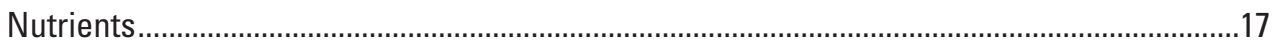

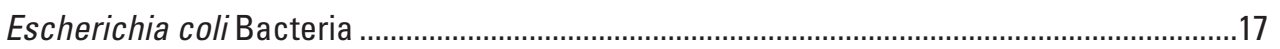

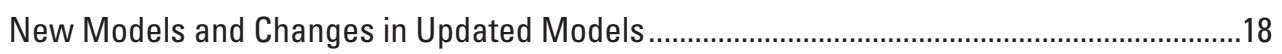

Turbidity, YSI Model 6026 and 6136 Sensors .............................................................................18

Computed Constituent Concentrations, Loads, and Yields ...........................................................19

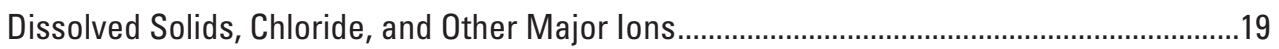

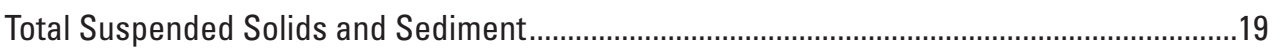

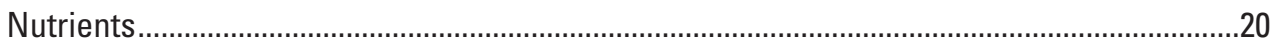

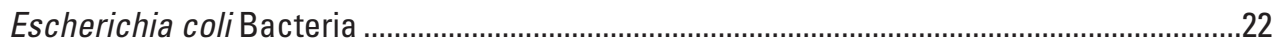

Comparison of Total Suspended Solids, Nitrate, and Total Phosphorus with Cheney

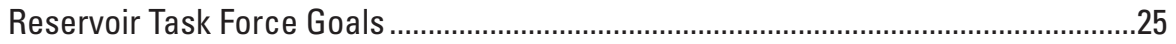

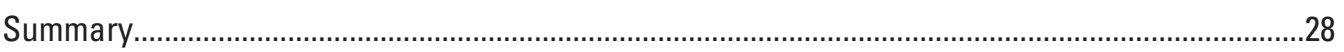

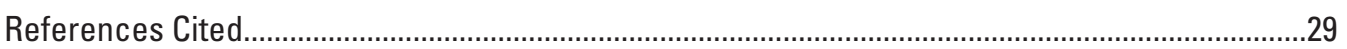




\section{Figures}

1. Map showing location of continuous real-time water-quality monitoring site and land use in the Cheney Reservoir watershed...

2. Map showing location of implemented best management practices in the Cheney Reservoir watershed, 1994-2011.....

3. Graphs showing duration curves for hourly measured streamflow, specific conductance, $\mathrm{pH}$, water temperature, dissolved oxygen, and turbidity at the North Fork Ninnescah River upstream from Cheney Reservoir, south-central Kansas, during 1999 through 2012.

4. Graphs showing relation between Yellow Springs Instruments model 6026 and YSI model 6136 turbidity sensor values at the North Fork Ninnescah River upstream from Cheney Reservoir, south-central Kansas, October 2009 through October 2010

5. Graphs showing duration curves for hourly computed dissolved solids, sodium, chloride, sulfate, total suspended solids, and suspended sediment at the North Fork Ninnescah River upstream from Cheney Reservoir, south-central Kansas, during 1999 through 2012

6. Graphs showing computed annual streamflow, total suspended solids, suspended-sediment, total nitrogen, nitrate, and total phosphorus loads at the North Fork Ninnescah River upstream from Cheney Reservoir south-central Kansas, during 1999 through 2012.

7. Graphs showing duration curves for hourly computed total nitrogen, nitrate, total phosphorus, and Escherichia coli bacteria at the North Fork Ninnescah River upstream from Cheney Reservoir, south-central Kansas, during 1999 through 2012

8. Graphs showing annual mean streamflow, computed total suspended solids, computed nitrate, and computed total phosphorus concentrations during base flow, runoff, and long-term streamflow conditions at the North Fork Ninnescah River upstream from Cheney Reservoir, south-central Kansas, during 1999 through 2012 


\section{Tables}

1. Cheney Reservoir Task Force mean stream water-quality goals for total suspended solids, dissolved nitrate as nitrogen, and total phosphorus concentrations in Cheney Reservoir watershed streams during base flow, runoff, and long-term streamflow conditions 1

2. Total annual and annual mean precipitation during 1999 through 2012 and annual mean precipitation during 1954 through 2012 at the "Wichita Mid Continent Airport" (Global Historical Climatology Network-Daily:USW00003928) station1...

3. Summary statistics for variables measured continuously at the North Fork Ninnescah River upstream from Cheney Reservoir (site 07144780), south-central Kansas, for the period of record (daily) and 1999 through 2012 (hourly)

4. Christensen and others (2006), updated, and new regression models and summary statistics for continuous concentration computations for the North Fork Ninnescah River upstream from Cheney Reservoir (site 07144780), south-central Kansas, 1999 through 2009

5. Summary of hourly statistics for selected water-quality constituents computed with updated regression models and continuously measured variables at the North Fork Ninnescah River upstream from Cheney Reservoir (site 07144780), south-central Kansas, 1999 through 2012.

6. Annual means for continuously measured and computed constituents at the North Fork Ninnescah River upstream from Cheney Reservoir (site 07144780), south-central Kansas, during 1999 through 2012.

7. Computed annual loads and yields for selected constituents at the North Fork Ninnescah River upstream from Cheney Reservoir (site 07144780), south-central Kansas, during 1999 through 2012

8. Summary statistics for selected water-quality constituents computed with updated regression models and continuously measured physical properties at the North Fork Ninnescah River upstream from Cheney Reservoir (site 07144780), south-central Kansas, 1999 through 2012. 


\section{Appendix Tables}

1. Sample collection dates and streamflow conditions for discrete water-quality samples included in regression model development for the North Fork Ninnescah River upstream from Cheney Reservoir (site 07144780), south-central Kansas, 1999 through 2009 ...

2. Christensen and others (2006), updated, and new regression models and summary statistics for continuous concentration computations for the North Fork Ninnescah River upstream from Cheney Reservoir, south-central Kansas, 1999 through 2009

3. Tobit regression models and summary statistics for constituents with leftcensored data for the North Fork Ninnescah River (site 07144780) upstream from Cheney Reservoir, south-central Kansas, 1999 through 2009

4. Summary statistics for data used in turbidity sensor linear regression analyses for the North Fork Ninnescah River upstream from Cheney Reservoir, south-central Kansas, October 1999 through October 2010

5. Updated Christensen and others (2006) regression models for the North Fork Ninnescah River upstream from Cheney Reservoir (site 07144780), south-central Kansas

6. Updated new regression models for the North Fork Ninnescah River upstream from Cheney Reservoir, south-central Kansas . 


\section{Conversion Factors}

\begin{tabular}{|c|c|c|}
\hline Multiply & By & To obtain \\
\hline \multicolumn{3}{|c|}{ Length } \\
\hline inch (in.) & 2.54 & centimeter $(\mathrm{cm})$ \\
\hline foot (ft) & 0.3048 & meter $(\mathrm{m})$ \\
\hline meter $(\mathrm{m})$ & 3.281 & foot $(\mathrm{ft})$ \\
\hline mile (mi) & 1.609 & kilometer (km) \\
\hline micrometer $(\mu \mathrm{m})$ & 0.001 & millimeter $(\mathrm{mm})$ \\
\hline \multicolumn{3}{|c|}{ Area } \\
\hline square mile $\left(\mathrm{mi}^{2}\right)$ & 2.590 & square kilometer $\left(\mathrm{km}^{2}\right)$ \\
\hline square meter $\left(\mathrm{m}^{2}\right)$ & 10.76 & square feet $\left(\mathrm{ft}^{2}\right)$ \\
\hline \multicolumn{3}{|c|}{ Volume } \\
\hline milliliter $(\mathrm{mL})$ & 0.0338 & ounce, fluid (oz) \\
\hline cubic foot $\left(\mathrm{ft}^{3}\right)$ & 28.32 & cubic decimeter $\left(\mathrm{dm}^{3}\right)$ \\
\hline acre-foot (acre-ft) & 1,233 & cubic meter $\left(\mathrm{m}^{3}\right)$ \\
\hline \multicolumn{3}{|c|}{ Flow rate } \\
\hline cubic foot per second $\left(\mathrm{ft}^{3} / \mathrm{s}\right)$ & 0.02832 & cubic meter per second $\left(\mathrm{m}^{3} / \mathrm{s}\right)$ \\
\hline milligram per liter $(\mathrm{mg} / \mathrm{L})$ & 1 & parts per million (ppm) \\
\hline microgram per liter $(\mu \mathrm{g} / \mathrm{L})$ & 1 & parts per billion (ppb) \\
\hline \multicolumn{3}{|c|}{ Mass } \\
\hline milligram (mg) & 0.001 & $\operatorname{gram}(\mathrm{g})$ \\
\hline microgram $(\mu \mathrm{g})$ & 0.000001 & $\operatorname{gram}(\mathrm{g})$ \\
\hline ton per year (ton/yr) & 0.9072 & metric ton per year \\
\hline
\end{tabular}

Temperature in degrees Celsius $\left({ }^{\circ} \mathrm{C}\right)$ may be converted to degrees Fahrenheit $\left({ }^{\circ} \mathrm{F}\right)$ as follows:

${ }^{\circ} \mathrm{F}=\left(1.8 x^{\circ} \mathrm{C}\right)+32$

Temperature in degrees Fahrenheit $\left({ }^{\circ} \mathrm{F}\right)$ may be converted to degrees Celsius $\left({ }^{\circ} \mathrm{C}\right)$ as follows:

${ }^{\circ} \mathrm{C}=\left({ }^{\circ} \mathrm{F}-32\right) / 1.8$

Horizontal coordinate information is referenced to the North American Datum of 1983 (NAD 83).

Specific conductance is given in microsiemens per centimeter at 25 degrees Celsius $(\mu \mathrm{S} / \mathrm{cm}$ at $\left.25^{\circ} \mathrm{C}\right)$.

Concentrations of chemical constituents in water are given either in milligrams per liter (mg/L) or micrograms per liter ( $\mu \mathrm{g} / \mathrm{L})$. 


\title{
Continuous Real-Time Water-Quality Monitoring and Regression Analysis to Compute Constituent Concentrations and Loads in the North Fork Ninnescah River Upstream from Cheney Reservoir, South-Central Kansas, 1999-2012
}

\author{
By Mandy L. Stone, Jennifer L. Graham, and Jackline W. Gatotho
}

\begin{abstract}
Cheney Reservoir, located in south-central Kansas, is the primary water supply for the city of Wichita. The U.S. Geological Survey has operated a continuous real-time water-quality monitoring station since 1998 on the North Fork Ninnescah River, the main source of inflow to Cheney Reservoir. Continuously measured water-quality physical properties include streamflow, specific conductance, $\mathrm{pH}$, water temperature, dissolved oxygen, and turbidity. Discrete water-quality samples were collected during 1999 through 2009 and analyzed for sediment, nutrients, bacteria, and other water-quality constituents. Regression models were developed to establish relations between discretely sampled constituent concentrations and continuously measured physical properties to compute concentrations of those constituents of interest that are not easily measured in real time because of limitations in sensor technology and fiscal constraints.
\end{abstract}

Regression models were published in 2006 that were based on data collected during 1997 through 2003. This report updates those models using discrete and continuous data collected during January 1999 through December 2009. Models also were developed for four new constituents, including additional nutrient species and indicator bacteria. In addition, a conversion factor of 0.68 was established to convert the Yellow Springs Instruments (YSI) model 6026 turbidity sensor measurements to the newer YSI model 6136 sensor at the North Fork Ninnescah River upstream from Cheney Reservoir site. Newly developed models and 14 years of hourly continuously measured data were used to calculate selected constituent concentrations and loads during January 1999 through December 2012. The water-quality information in this report is important to the city of Wichita because it allows the concentrations of many potential pollutants of interest to Cheney Reservoir, including nutrients and sediment, to be estimated in real time and characterized over conditions and time scales that would not be possible otherwise.

In general, model forms and the amount of variance explained by the models was similar between the original and updated models. The amount of variance explained by the updated models changed by 10 percent or less relative to the original models. Total nitrogen, nitrate, organic nitrogen, Escherichia coli bacteria, and total organic carbon models were newly developed for this report. Additional data collection over a wider range of hydrological conditions facilitated the development of these models. The nitrate model is particularly important because it allows for comparison to Cheney Reservoir Task Force goals.

Mean hourly computed total suspended solids concentration during 1999 through 2012 was 54 milligrams per liter $(\mathrm{mg} / \mathrm{L})$. The total suspended solids load during 1999 through 2012 was 174,031 tons. On an average annual basis, the Cheney Reservoir Task Force runoff $(550 \mathrm{mg} / \mathrm{L})$ and longterm $(100 \mathrm{mg} / \mathrm{L})$ total suspended solids goals were never exceeded, but the base flow goal was exceeded every year during 1999 through 2012. Mean hourly computed nitrate concentration was $1.08 \mathrm{mg} / \mathrm{L}$ during 1999 through 2012. The total nitrate load during 1999 through 2012 was 1,361 tons. On an annual average basis, the Cheney Reservoir Task Force runoff nitrate goal $(6.60 \mathrm{mg} / \mathrm{L})$ was never exceeded, the longterm goal $(1.20 \mathrm{mg} / \mathrm{L})$ was exceeded only in 2012 , and the base flow goal of $0.25 \mathrm{mg} / \mathrm{L}$ was exceeded every year. Mean nitrate concentrations that were higher during base flow, rather than during runoff conditions, suggest that groundwater sources are the main contributors of nitrate to the North Fork Ninnescah River above Cheney Reservoir. Mean hourly computed phosphorus concentration was $0.14 \mathrm{mg} / \mathrm{L}$ during 1999 through 2012. The total phosphorus load during 1999 through 2012 was 328 tons. On an average annual basis, the Cheney Reservoir Task Force runoff goal of $0.40 \mathrm{mg} / \mathrm{L}$ for total phosphorus was exceeded in 2002, the year with the largest 
yearly mean turbidity, and the long-term goal $(0.10 \mathrm{mg} / \mathrm{L})$ was exceeded in every year except 2011 and 2012, the years with the smallest mean streamflows. The total phosphorus base flow goal of $0.05 \mathrm{mg} / \mathrm{L}$ was exceeded every year. Given that base flow goals for total suspended solids, nitrate, and total phosphorus were exceeded every year despite hydrologic conditions, the established base flow goals are either unattainable or substantially more best management practices will need to be implemented to attain them.

On an annual average basis, no discernible patterns were evident in total suspended sediment, nitrate, and total phosphorus concentrations or loads over time, in large part because of hydrologic variability. However, more rigorous statistical analyses are required to evaluate temporal trends. A more rigorous analysis of temporal trends will allow evaluation of watershed investments in best management practices.

\section{Introduction}

Cheney Reservoir (fig. 1), located in south-central Kansas, was constructed between 1962 and 1965 by the Bureau of Reclamation, U.S. Department of the Interior, to provide a municipal water supply for the city of Wichita, downstream flood control, wildlife habitat, and recreational areas. From 1995 through 2010, water from Cheney Reservoir contributed between 51 and 69 percent of Wichita's water supply (Ziegler and others, 2010). Water-supply needs and reliance on Cheney Reservoir will continue to increase with ongoing population growth and urban development.

Cyanobacterial blooms can be harmful, and may result in high concentrations of toxins and taste-and-odor causing compounds. Taste-and-odor problems are a concern to drinking-water suppliers because of customer dissatisfaction with unpalatable drinking water and increased treatment costs to remove taste-and-odor causing compounds (Taylor and others, 2005). Sedimentation decreases reservoir life, may have a negative effect on benthic organisms, and creates lower light conditions which may favor cyanobacterial growth and proliferation (Waters, 1995; Chorus and Bartram, 1999; Graham and others, 2008). Excessive nutrients also may cause cyanobacterial blooms. Decomposition of these blooms may cause oxygen depletion and fish kills (Wehr and Sheath, 2003). The reduction in transport of sediment and nutrients would reduce excessive sedimentation and may reduce taste-and-odor problems in Cheney Reservoir by decreasing cyanobacterial abundance.

Taste-and-odor occurrences in Cheney Reservoir in 1990 and 1991 prompted a task force to be formed in 1992. The Cheney Reservoir Task Force was asked to prepare a pollution management plan to identify and mitigate sources of water pollution in the watershed. The Cheney Reservoir Task Force consisted of members of the Reno and Sedgwick County Conservation Districts, Reno County Health Department, Wichita Water and Sewer Department, and other local, State, and
Federal agencies. The Cheney Reservoir Task Force prepared a water-quality plan to abate the transport of suspended solids, nutrients, and pesticides into the reservoir.

The Cheney Reservoir Task Force identified total phosphorus and total suspended solids as primary pollutants of concern because of their relation to taste-and-odor producing cyanobacterial blooms and the effect they have on the quality and quantity of water in Cheney Reservoir. The Cheney Reservoir Task Force established stream water-quality goals for total suspended solids, nitrate, and total phosphorus during base flow, runoff, and long-term streamflow conditions (table 1; Cheney Reservoir Task Force, 1994). Total phosphorus and total suspended-solids concentration goals were established to reduce pollution and extend the life of Cheney Reservoir from 130 to 200 years (Cheney Reservoir Task Force, 1994). To achieve these goals, approximately 1,500 contracts were established for implementation of best management practices (BMPs) in the Cheney Reservoir watershed between 1994 and 2011 and Conservation Reserve Program (CRP) land increased by approximately 20,475 acres (fig. 2; Cheney Lake Watershed Incorporated, written commun., 2011).

The U.S. Geological Survey (USGS), in cooperation with the city of Wichita, has continuously monitored water quality on the North Fork Ninnescah River upstream from Cheney Reservoir (USGS stream-gaging station 07144780; fig. 1) since October 1998. Streamflow has been measured continuously on the North Fork Ninnescah River above Cheney Reservoir since July 1965. Water budget analysis during 1997 through 2003 indicated that the North Fork Ninnescah River contributes about 70 percent of the water flowing into the reservoir (Christensen and others, 2006). Water-quality monitoring on the North Fork Ninnescah River provides hourly measures of specific conductance, $\mathrm{pH}$, water temperature, dissolved oxygen, and turbidity. Numerous discrete water-quality samples have been collected at this site and used to develop regression models establishing relations between continuously monitored water-quality physical properties and water-quality constituents of interest that are not monitored continuously. These models are useful for evaluating concentrations of water-quality constituents to compare with water-quality criteria, and for computing loads and yields to assess watershed transport.

Twelve years (1997 through 2008) of regressioncomputed total suspended solids and total phosphorus data for the North Fork Ninnescah River were compared with the water-quality goals set by the Cheney Reservoir Task Force (Stone and others, 2009; table 1). Base flow total suspended solids and total phosphorus goals were not met based on 1997 through 2008 data; however, long-term and runoff total suspended solids and runoff total phosphorus goals rarely were exceeded. Because total suspended solids and total phosphorus concentrations exceeded base flow goals in 2006, an extremely dry year, it was concluded that the established base flow goals may be unattainable or substantially more BMPs would be needed to attain them. The current (2013) study is a more comprehensive evaluation of water-quality conditions and 


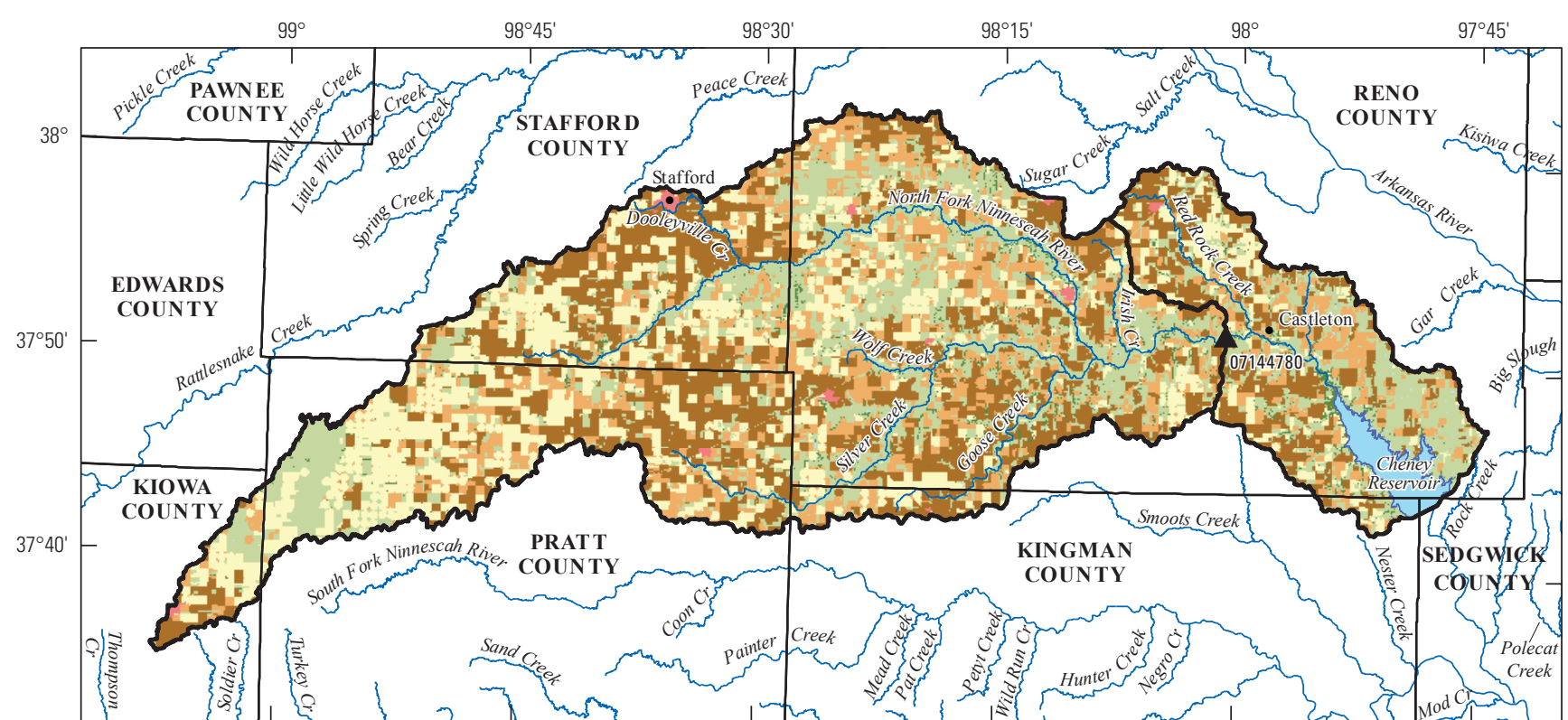

Base modified from U.S. Geological Survey 1:100,000-scale digital data, 2005

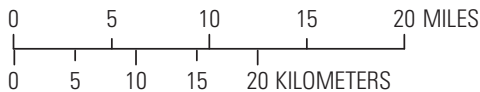

EXPLANATION

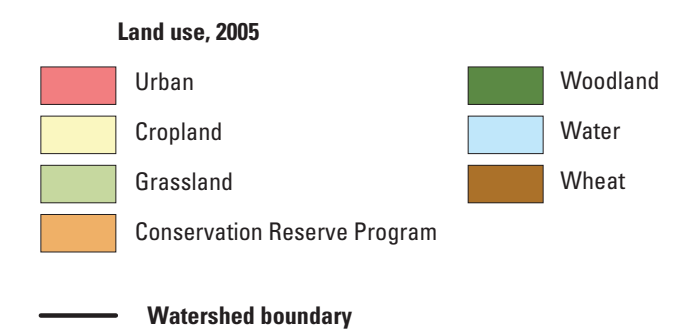

07144780

Figure 1. Location of continuous real-time water-quality monitoring site and land use in the Cheney Reservoir watershed.

watershed transport of constituents of concern in the North Fork Ninnescah River, the main tributary to, and thus one of the key contributors to, water quality in Cheney Reservoir. Previously published models were improved by incorporating more data, models for additional constituents were developed, and loads were calculated for a longer time period using the updated models.

\section{Purpose and Scope}

The purpose of this report is to update regression models that establish relations between continuous and discrete water-quality data collected from the North Fork Ninnescah River upstream from Cheney Reservoir (USGS site 07144780; fig. 1). The models are used to compute concentrations and loads for 20 water-quality constituents of interest and to describe water-quality during 1999 through 2012.
Table 1. Cheney Reservoir Task Force mean stream waterquality goals for total suspended solids, dissolved nitrate as nitrogen, and total phosphorus concentrations in Cheney Reservoir watershed streams during base flow, runoff, and longterm streamflow conditions. ${ }^{*}$

\begin{tabular}{lccc}
\hline \multirow{2}{*}{ Water-quality constituent } & \multicolumn{3}{c}{$\begin{array}{c}\text { Mean water-quality goal } \\
\text { (milligrams per liter) }\end{array}$} \\
\cline { 2 - 4 } & Base flow & Runoff & Long term \\
\hline Total suspended solids & 20 & 550 & 100 \\
Dissolved nitrate as nitrogen & 0.25 & 6.60 & 1.20 \\
Total phosphorus & 0.05 & 0.40 & 0.10 \\
\hline
\end{tabular}

"Cheney Reservoir Task Force, 1994. 


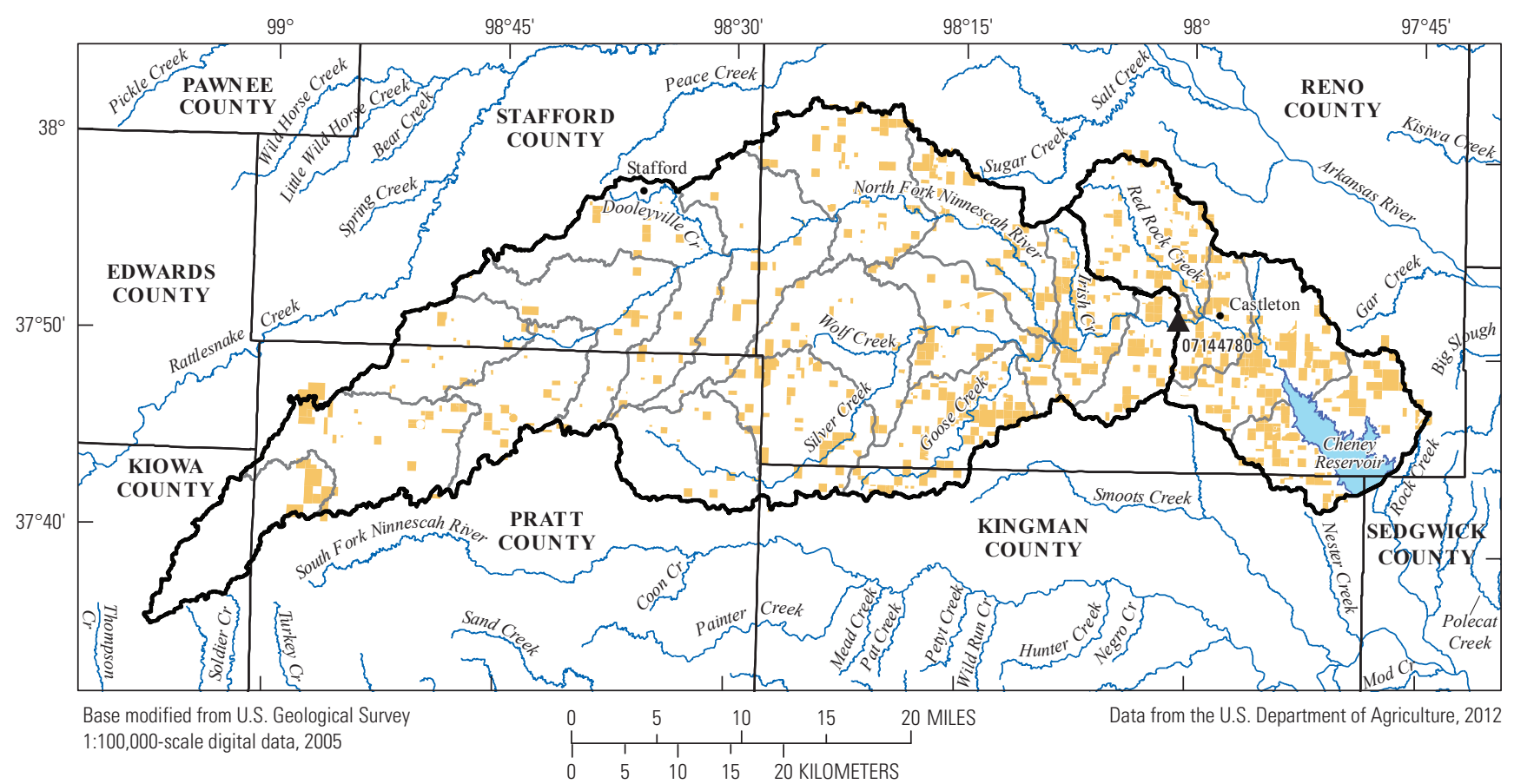

EXPLANATION

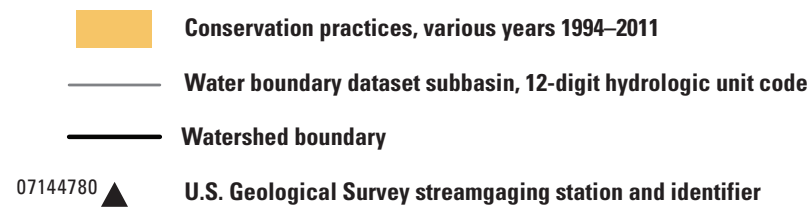

Figure 2. Location of implemented best management practices in the Cheney Reservoir watershed, 1994-2011.

Regression models originally were published by Christensen and others (2006) using data collected during 1997 through 2003 for 15 water-quality constituents, including total suspended solids, suspended-sediment, dissolved solids and major ions, total Kjeldahl nitrogen, total phosphorus, orthophosphate, and fecal coliform bacteria. In this report, those regression models are updated using data collected through 2009, and additional models are developed for nitrate, organic nitrogen, Escherichia coli (E. coli) bacteria, and total organic carbon. A site-specific relation between continuous turbidity measurements from the older Yellow Springs Instruments (YSI) model 6026 and newer YSI model 6136 turbidity sensors also was developed so the YSI 6026 sensor could be replaced with the YSI 6136 sensor while retaining the ability to make comparisons to historical data. The updated and new models in this report are useful for evaluating concentrations of water-quality constituents to compare with water-quality criteria and for computing loads and yields to assess constituent transport through the watershed. The water-quality information in this report is important to the city of Wichita because it quantifies and characterizes potential pollutants, including nutrients and sediment, transported into Cheney Reservoir.

\section{Description of Study Area}

The Cheney Reservoir watershed is located in southcentral Kansas (fig. 1) and has a contributing drainage area of 933 square miles $\left(\mathrm{mi}^{2}\right)$. The North Fork Ninnescah River is the largest tributary to Cheney Reservoir and contributes about 70 percent of the inflow (Christensen and others, 2006). The North Fork Ninnescah River above Cheney Reservoir, Kansas monitoring site (USGS stream-gaging station number 07144780), where continuous water-quality data have been collected since October 1998, has a drainage area of $734 \mathrm{mi}^{2}$.

Land use in the Cheney Reservoir watershed predominately is rural (fig. 1); less than 1 percent of the land use in the watershed is classified as urban. All agricultural crops, including wheat, comprise about 55 percent of land use in the watershed above the North Fork Ninnescah River site. About 25 percent of the North Fork Ninnescah River site's watershed is grassland and about 18 percent is conservation reserve program (CRP) land (Peterson and others, 2005).

The mean annual temperature (1954 through 2012) in the study area is 57 degrees Fahrenheit $\left({ }^{\circ} \mathrm{F}\right)$ and was approximately 1 degree higher $\left(58^{\circ} \mathrm{F}\right)$ for the 1999 through 2012 study period (National Climatic Data Center, 2012). Mean 
annual precipitation in the study area was about 31 inches during 1954 through 2012, and averaged 34 inches for the period during 1999 through 2012 ("Wichita Mid Continent Airport" station; National Climatic Data Center, 2012; table 2).

Kansas Department of Health and Environment (KDHE) defined designated uses for several streams within the Cheney Reservoir watershed (figs. 1, 2; Kansas Department of Health and Environment, 2010). Domestic water supply, food procurement (obtaining edible aquatic life for human consumption), groundwater recharge, industrial water supply, irrigation, and livestock watering are designated uses for parts of the North Fork Ninnescah River, Red Rock Creek, and Silver Creek. Food procurement, groundwater recharge, irrigation, and livestock watering are designated uses for Dooleyville Creek and Goose Creek. Domestic water supply, groundwater recharge, industrial water supply, irrigation, and livestock watering are designated uses for Rock Creek, Spring Creek, and Wolf Creek. Within the Cheney Reservoir watershed, Goose Creek, Red Rock Creek, and Silver Creek (figs. 1, 2) have food procurement as a designated use.

KDHE has listed one stream in the North Fork Ninnescah River watershed and Cheney Reservoir as impaired waterways under section 303(d) of the 1972 Clean Water Act (Kansas Department of Health and Environment, 2012). Atrazine in Red Rock Creek (fig. 1) is listed as a pollutant impairing aquatic life. Siltation is listed as an impairment to water

Table 2. Total annual and annual mean precipitation during 1999 through 2012 and annual mean precipitation during 1954 through 2012 at the "Wichita Mid Continent Airport" (Global Historical Climatology Network-Daily:USW00003928) station."

\begin{tabular}{cc}
\hline Year or time period & Total precipitation, in inches \\
\hline 1999 & 45 \\
2000 & 32 \\
2001 & 24 \\
2002 & 33 \\
2003 & 33 \\
2004 & 38 \\
2005 & 37 \\
2006 & 29 \\
2007 & 38 \\
2008 & 54 \\
2009 & 38 \\
2010 & 28 \\
2011 & 26 \\
2012 & 25 \\
Average annual during & 34 \\
Average annual during & \\
1954 through 2012 & 31 \\
\hline
\end{tabular}

"National Climatic Data Center data available at $h t t p: / / w w w . n c d c . n o a a$. gov/oa/ncdc.html. supply, and eutrophication and $\mathrm{pH}$ are listed as impairments to aquatic life in Cheney Reservoir. The North Fork Ninnescah River watershed had a total maximum daily load (TMDL) for $\mathrm{pH}$ starting above Cheney Reservoir and ending in Stafford County near Stafford (fig. 1) that was delisted in 2010; the water-quality standard stated that "artificial sources of pollution shall not cause the $\mathrm{pH}$ of any surface water outside the zone of initial dilution to be below 6.5 or above 8.5" (Kansas Department of Health and Environment, 2001).

\section{Related Water-Quality Studies}

Since 1996, USGS has conducted several studies in the Cheney Reservoir watershed in cooperation with the city of Wichita, Kansas. During June and September 1996, the spatial variability in concentrations of dissolved nutrients, atrazine, and fecal coliform bacteria was evaluated at 34 sites in the Cheney Reservoir watershed during low-flow conditions. With the exception of dissolved solids, which generally originated from natural sources, these constituents originated from nonpoint sources associated with agricultural activities (Christensen and Pope, 1997). Phosphorus was identified as a constituent of concern that could increase the growth of cyanobacteria, thereby increasing the occurrence of taste-andodor episodes (Pope and Christensen, 1997; Pope, 1998; and Pope and Milligan, 2000). Phosphorus control measures were suggested as a method to mitigate the taste-and-odor occurrences which were strongly linked to growth of cyanobacteria (Smith and others, 2001).

Sediment deposition, water-quality trends, and mass transport of phosphorus, nitrogen, selected trace elements, and selected pesticides within the Cheney Reservoir watershed were investigated using bathymetric survey data and reservoir bottom sediment cores collected during 1997 through 1999. Core analysis indicated total phosphorus concentrations in reservoir bottom sediment had increased with time, which was likely the result of nonpoint source activities in the watershed, such as increased fertilizer use and livestock production (Mau, 2001). Sediment concentrations of arsenic, chromium, copper, and nickel at many sites exceeded levels at which adverse effects on aquatic organisms may occur, but these compounds likely were of natural origin in the watershed (Mau, 2001). Soil cores were examined from 43 nonagricultural sites in the Cheney Reservoir watershed. Historical mean total phosphorus concentrations in the bottom sediment of Cheney Reservoir were approximately 3 times larger than the natural concentrations found in the sample cores collected from nonagricultural watershed soils, indicating that agricultural activities within the watershed have increased total phosphorus concentrations in soil to about 3 times natural concentrations (Pope and others, 2002). Results also indicated that water from two of five streamflow sampling sites did not meet the Cheney Reservoir Task Force long-term total phosphorus water-quality goal of $0.10 \mathrm{mg} / \mathrm{L}$. 
Regression models relating constituent concentrations from discretely collected samples to continuously measured physical properties at the North Fork Ninnescah River above Cheney Reservoir site (hereinafter called the inflow site) were developed using data collected during January 1997 through April 2003. These models were used to compute concentrations of sediment, nutrients, bacteria, and other water-quality constituents (Christensen and others, 2006). Regression-computed concentrations of total suspended solids from the inflow site during 2001 through 2003 were near the Cheney Reservoir Task Force base flow goal most of the time. The long-term goal was exceeded only during periods of runoff and the runoff goal was exceeded several times during 2001 through 2003 (Christensen and others, 2006). The regression-computed total phosphorus concentration always exceeded the base flow goal during 2001 through 2003, and was close to the long-term goal during base flow conditions; the runoff goal was exceeded several times during 2001 and 2002 and during three high flow periods in 2003 (Christensen and others, 2006). Using the Christensen and others (2006) models [hereinafter referred to as original model(s)], Cheney Reservoir Task Force base flow goals for total suspended solids and total phosphorus goals were not met during 1997 through 2008 (Stone and others, 2009).

\section{Methods}

Continuous and discrete water-quality data were collected at one site on the North Fork Ninnescah River (fig. 1; USGS stream-gaging station 07144780, North Fork Ninnescah River above Cheney Reservoir). The North Fork Ninnescah River is the largest contributing tributary to Cheney Reservoir, and thus one of the main contributors to reservoir water quality. Streamflow has been measured continuously at the inflow site since July 1965 and water quality has been measured continuously since October 1998. Discrete water-quality samples routinely have been collected since February 1996. Continuous and discrete water-quality data collected by the USGS at the inflow site from January 1999 through December 2009 were used to develop updated and new site-specific regression models. Continuously measured water-quality data collected during January 1999 through December 2012 were used to compute concentrations, loads, and yields for water-quality constituents of interest, and evaluate water-quality conditions.

\section{Continuous Water-Quality Monitoring}

Continuous water-quality data were collected from the inflow site and were recorded hourly. Streamflow was measured using standard USGS methods (Sauer and Turnipseed, 2010; Turnipseed and Sauer, 2010). The inflow site was equipped with a YSI 6600 Extended Deployment System water-quality monitor that measured specific conductance, $\mathrm{pH}$, water temperature, dissolved oxygen (YSI Clark cell or optical dissolved oxygen sensors), and turbidity (YSI model 6026 or 6136 optical turbidity sensors). The YSI Clark cell dissolvedoxygen sensor was used from November 1998 through March 2008 and was replaced by the YSI optical dissolved-oxygen sensor from March 2008 through 2012. The YSI model 6026 turbidity sensor was used during December 1998 through May 2011 and the YSI model 6136 turbidity sensor was used from October 2009 through 2012. The monitor was installed near the centroid of streamflow to best represent conditions across the width of the stream and was maintained in accordance with standard USGS procedures (Wilde and Radke, 1998; Wagner and others, 2006). Continuous streamflow and water-quality data were recorded hourly and are available on the USGS website at $h t t p: / / n r t w q . u s g s . g o v / k s$.

The specific conductance, $\mathrm{pH}$, water temperature, and dissolved oxygen sensors have wide ranges of operation (Wagner and others, 2006) that were not exceeded in this study. Individual turbidity sensors vary in maximum readings. The maximum reading recorded at this site during 1999 through 2012 was 1,700 formazin nephelometric units (FNU) and the instrument maximum was not exceeded during the study period. Continuous data during the study period generally required corrections of less than 10 percent, which classifies the data quality as "good" according to established guidelines (Wagner and others, 2006). Time-series measurements occasionally were missing or deleted from the dataset because of low-flow conditions, equipment malfunction, or excessive fouling caused by environmental conditions. During 1999 through 2012, less than 1 percent of the streamflow record, approximately 7 percent of the specific conductance record, 5 percent of the $\mathrm{pH}$ record, 3 percent of the water temperature record, 8 percent of the dissolved oxygen record, and 7 percent of the turbidity record were missing or deleted (table 3), largely because of low-flow conditions causing sensors to be out of water and, in some cases, sensor fouling.

\section{Discrete Water-Quality Samples}

Discrete water-quality samples were collected over a range of streamflow conditions (appendix 1) during January 1999 through September 2009 using depth- and width- integrating sample-collection techniques (Wilde and Radke, 1998; U.S. Geological Survey, 2006). Samples collected using this approach are representative of the average chemical composition of the stream cross-sectional area. All water samples were analyzed for dissolved solids and major ions, alkalinity, suspended solids and sediment, nutrients (nitrogen and phosphorus species), indicator bacteria, and organic carbon. Dissolved and suspended solids, major ions, alkalinity, nutrients (except for total Kjeldahl nitrogen), fecal coliform bacteria, and organic carbon were analyzed by the Wichita Municipal Water and Wastewater Laboratory in Wichita, Kansas according to standard methods (American Public Health Association and others, 1995). Selected replicate samples were sent to the USGS National Water Quality Laboratory in Lakewood, 
Table 3. Summary statistics for variables measured continuously at the North Fork Ninnescah River upstream from Cheney Reservoir (site 07144780), south-central Kansas, for the period of record (daily) and 1999 through 2012 (hourly).

[Continuous real-time water-quality data are available on the U.S. Geological Survey National Real-Time Water-Quality Web site (http://nrtwq.usgs. gov $/ \mathrm{ks}) ; n$, number of measurements; $\mathrm{ft}^{3} / \mathrm{s}$, cubic feet per second; $\mu \mathrm{S} / \mathrm{cm}$, microsiemens per centimeter at 25 degrees Celsius; ${ }^{\circ} \mathrm{C}$, degrees Celsius; $\mathrm{mg} / \mathrm{L}$, milligrams per liter; FNU, formazin nephelometric units; <, less than]

\begin{tabular}{|c|c|c|c|c|c|c|}
\hline Continuous variable & $n$ & Minimum & Maximum & Mean & Median & $\begin{array}{c}\text { Percent } \\
\text { missing } \\
\text { data }\end{array}$ \\
\hline Daily streamflow $\left(\mathrm{ft}^{3} / \mathrm{s}\right)$, for period of record* & 17,351 & 0 & 39,700 & 141 & 78.0 & 0 \\
\hline Hourly streamflow $\left(\mathrm{ft}^{3} / \mathrm{s}\right)^{* *}$ & 122,627 & 0 & 8,460 & 129 & 84 & 0.1 \\
\hline Hourly specific conductance $(\mu \mathrm{S} / \mathrm{cm})$ & 113,955 & 103 & 1,760 & 1,144 & 1,170 & 7.2 \\
\hline Hourly pH & 117,224 & 7.0 & 9.5 & 8.3 & 8.4 & 4.5 \\
\hline Hourly water temperature $\left({ }^{\circ} \mathrm{C}\right)$ & 118,673 & -0.2 & 39.8 & 15.1 & 15.4 & 3.3 \\
\hline Hourly dissolved oxygen $(\mathrm{mg} / \mathrm{L})$ & 112,851 & 2.1 & 18.4 & 10.2 & 10.0 & 8.1 \\
\hline Hourly turbidity (FNU) & 114,091 & $<1.0$ & 1,700 & 44 & 25 & 7.0 \\
\hline
\end{tabular}

*The period of record is July 1965 through December 2012.

${ }^{* *}$ The period during 1999 through 2012.

Colorado and analyzed according to methods presented in Fishman and Friedman (1989). E. coli was analyzed at the USGS Wichita Field Office in Wichita, Kansas using methods described by Wilde and Radke (1998). Suspended sediment was analyzed at the USGS Iowa Sediment Laboratory in Iowa City, Iowa according to methods described in Guy (1969).

\section{Quality Assurance and Quality Control}

Replicate, standard reference, and blank samples were collected over a range of streamflow conditions as part of quality assurance/quality control (QA/QC). About 8 percent of discrete water-quality samples were $\mathrm{QA} / \mathrm{QC}$ samples. Approximately 180 sequential replicate constituent pairs were collected during 1999 through 2009 for the inflow site. Replicate samples were analyzed to identify variability in sampling and analysis methods (Wilde and Radke, 1998). Relative percentage difference (RPD) was used to evaluate differences in analyte concentrations detected in replicate water samples. The RPD was calculated using the following equation:

$$
R P D=\left[|A-B| /\left(\frac{A+B}{2}\right)\right] \times 100
$$

where $A$ and $B$ are concentrations in each replicate pair. Replicate pairs with an RPD within 10 percent were considered acceptable for inorganic constituents (Ziegler and Combs, 1997). Replicate pairs with an RPD within 20 percent were considered acceptable for organic constituents (including total phosphorus), and RPDs within 50 percent were considered acceptable for bacterial analysis. The median RPD between all constituent replicate pairs was less than their respective acceptability limits. All constituent replicate pairs had median RPDs that were less than 5 percent, except for total Kjeldahl nitrogen (12 percent), total phosphorus (15 percent), E. coli (25 percent), and suspended sediment (6 percent). Larger RPDs generally occurred when the values were near the method reporting level.

Approximately 65 sequential constituent replicate pairs were analyzed by the Wichita Municipal Water and Wastewater Laboratory and the USGS National Water Quality Laboratory. The median RPD between laboratories for ions was 6 percent. The median RPD between laboratories for nutrients was 12 percent. Larger nutrient RPDs generally occurred because of differences in laboratory method reporting levels and when the values were at or near the method or laboratory reporting level.

Blank sample analysis included approximately 210 constituent concentrations. All constituents were below the method reporting level with the exception of ammonia. One ammonia value was $0.01 \mathrm{mg} / \mathrm{L}$ above the method reporting level. Median blank bicarbonate concentration was $2.4 \mathrm{mg} / \mathrm{L}$. Median blank alkalinity concentration was $2.0 \mathrm{mg} / \mathrm{L}$.

Standard reference samples were analyzed by the Wichita Municipal Water and Wastewater Laboratory at least annually and submitted to the USGS Branch of Quality Systems for sample analysis and evaluation of laboratory performance. Median major ion constituent RPDs ranged from 1 to 6 percent and median nutrient constituent RPDs ranged from 3 to 5 percent during this study. Results are available at $h t t p: / / b q s$. usgs.gov/srs/.

Cross-sectional measurements of water-quality physical properties measured with an independent field water-quality monitor were compared to concomitant continuous measurements to provide verification that minimum bias occurred as a result of water-quality monitor location within the stream cross-section. Cross-sectional water-quality physical properties were measured during discrete sampling and measurements across the stream channel at ten evenly spaced locations 
were recorded. The median RPD between cross-sectional and concomitant continuous monitor measurements was approximately 2 percent for all measurements. Larger differences (greater than 5 percent RPD) between cross-sectional and continuous monitor measurements occurred during stormwater runoff events when conditions were changing rapidly.

\section{Development of Regression Models to Compute Constituent Concentrations}

Models were developed using simple linear (ordinary least squares) regression analyses to relate discrete sample concentrations or densities of water-quality constituents to continuously measured water-quality physical properties (Helsel and Hirsch, 2002; Rasmussen and others, 2008). The methods used for the development of these models, quantifying uncertainty, and computation of loads and yields are described in detail in Rasmussen and others (2009). All data for this report were analyzed using TIBCO Spotfire $\mathrm{S}+{ }^{\circledR} 8.1$ for Windows ${ }^{\circledR}$ statistical software (TIBCO Software, Inc., 2008). Stone and others (2013) provide model documentation, including datasets and $\mathrm{S}+{ }^{\circledR}$ statistical output.

Although Christensen and others (2006) included discrete data collected in 1997 and 1998 in their regression analyses, these data were not included in the current analysis. Christensen and others (2006) used cross-sectional means of continuously measured physical properties as explanatory variables, whereas this current analysis uses continuously measured water-quality data after the Rasmussen and others (2009) protocol. Christensen and others (2006) also included discrete data collected by autosamplers as response variables; this report did not use autosampled data because the autosamples represented a relatively small part of the dataset and may not be representative of the average chemical composition of the stream cross-sectional area (Christensen and others, 2006; Rasmussen and others, 2008). Original models had numbers of discrete samples ranging from 20 to 127, with a median of 27 . The numbers of discrete samples for models in this report range from 22 to 61 , with a median of 54 .

All continuously measured variables and seasonal components (sine and cosine variables) were tested for significance for each response variable. Concomitant in-stream continuous measurements were used to correspond with discrete measurements as described in Rasmussen and others (2009). In-stream continuous data corresponding to each discrete sample were determined from time-series datasets by using time-weighted averages of continuous data values recorded immediately before, during, and after the discrete sample collection.

Outliers were identified and removed as described in Rasmussen and others (2009). Outliers in discrete samples were removed when there was large heterogeneity in corresponding physical properties of cross-sectional data recorded during discrete sampling and when there were issues with laboratory analysis (such as an orthophosphate concentration being higher than the concomitant total phosphorus concentration).
Overall, approximately 5 percent of the discrete-sample data were considered outliers and were removed from regression models. Three percent of the discrete-sample data was removed because of large heterogeneity in corresponding physical properties of cross-sectional data recorded during discrete sampling. One percent of the discrete-sample data was removed because of a large specific conductance value likely affected by road salt application. One percent of the discrete-sample data was removed because of laboratory analysis issues. Uncertainty in regression model predictions is unknown when the cross-sectional measurements vary greatly from the in situ measurements and when road salt is applied.

Regression models were evaluated based on diagnostic statistics $\left[R^{2}\right.$, coefficient of determination; Mallow's $C_{\mathrm{p}}$; root mean square error (RMSE); PRESS, prediction error sum of squares], patterns in residual plots, and the range and distribution of discrete and continuous data. The best model for each constituent was selected to maximize the amount of variance in the response variable that is explained by the model (multiple $R^{2}$ for models with one explanatory variable and adjusted $R^{2}$ for models with more than one explanatory variable), that best fit the data (Mallow's $C_{\mathrm{p}}$ ), and that minimized heteroscedasticity (irregular scatter) in the residual plots and uncertainty associated with computed values (RMSE and PRESS). Model simplicity also was considered for model selection because, as more variables are included, the likelihood increases that the variability of the system is not described by the sampling dataset.

Mean square error (MSE) and RMSE was calculated for each model to assess the variance between predicted and observed values (Helsel and Hirsch, 2002). The model standard percentage error $(M S P E)$ was calculated as a percentage of the RMSE (Hardison, 1969). Because transformation of estimates back into original units results in a low biased estimate (Helsel and Hirsch, 2002), a bias correction factor (BCF) was calculated for models with logarithmically transformed response variables (Duan, 1983).

To avoid false-positive quantification of a constituent, low concentrations are left-censored and reported as "less than" values by the laboratory (Childress and others, 1999). Two constituents had left-censored data: organic nitrogen (15 percent of samples) and orthophosphate (33 percent of samples). These data initially were analyzed using tobit regression (Judge and others, 1985). After the tobit regressions were completed, the left-censored data arbitrarily were assigned a value of one-half of the censoring level and were analyzed in the same manner as the constituents without left-censored data for comparison with the tobit regressions.

\section{Calculation of Annual Streamflow-Separation Points and Constituent Loads and Yields}

Continuous hourly concentrations of select constituents were calculated using the newly developed regression models and continuous water-quality data (available online at 
http://nrtwq.usgs.gov/ks/). Measured and computed continuous concentration data were evaluated from January 1, 1999, through December 31, 2012. Continuous data occasionally were missing during periods when extreme weather conditions occurred, water-quality monitors malfunctioned, or during routine maintenance visits. Two methods were used to compute constituent concentrations during periods of missing continuous data. Continuous hourly measurements were linearly interpolated when one or two values were missing using the least squares method (Sokal and Rohlf, 1995). When more than two values of hourly data were missing, a streamflow-based regression model was used to compute continuous concentrations because flow data were available for almost all ( 99.9 percent) of the period. Computed constituent concentration data varied because of differences in continuously monitored data-based and streamflow-based regression models. To "smooth" out steps in computed constituent concentration data from the different regression models, the streamflow-based constituent concentrations were shifted to the next available continuous datum based on methods described in Porterfield (1972). When no flow or other continuous data were available, concentrations, loads, and yields were not computed. Uncertainty associated with regression-computed constituent concentrations was quantified using 90-percent prediction intervals (Helsel and Hirsch, 2002).

Duration curves are cumulative distribution functions and were constructed using hourly values to evaluate frequency and magnitude characteristics (Rasmussen and Ziegler, 2003; Rasmussen and others, 2005). The curves indicate either the percentage of time that specified conditions were equaled or exceeded, or the frequency of exceedance (Maidment, 1993). The Weibull formula (Helsel and Hirsch, 2002) was used for calculating plotting position. Streamflow and water-quality constituent duration curves with uncertainty, represented by 90-percent prediction intervals, for the inflow site are available for the period of record on the USGS website at $h t t p: / / n r t w q . u s g s . g o v / k s /$. Water-quality criteria exceedances were determined using duration curves. Because of uncertainty associated with quantifying criteria exceedances on the basis of duration curves, the exceedances in this report should be considered as approximations. All duration curves for computed constituent concentrations in this report are plotted with 90-percent prediction intervals.

Definition of streamflow conditions was required to compare water-quality conditions to Cheney Reservoir Task Force goals for total suspended solids, nitrate, and total phosphorus (table 1). The discharge duration curve calculated from hourly discharge data during January 1999 through December 2012 was used to define base flow, runoff, and long-term streamflow conditions for the entire 14-year period. A 10 percent streamflow-separation point, determined by the discharge duration curve, was used to define base flow and runoff conditions following KDHE's TMDL curve methodology for characterizing flood conditions (Kansas Department of Health and Environment, [n.d.]).

Load and yield data were calculated from January 1, 1999, through December 31, 2012. Hourly constituent loads were calculated by multiplying the calculated hourly concentrations (in milligrams per liter; $\mathrm{mg} / \mathrm{L}$ ) determined by regression models by hourly streamflow (in cubic feet per second; $\mathrm{ft}^{3} / \mathrm{s}$ ) and a unit conversion factor (0.22427). This calculation assumes that hourly computed instantaneous load was constant during the preceding hour. Annual loads were calculated by summing the hourly loads. Annual yields (in pounds per acre) were calculated by dividing the annual loads by the contributing drainage at the inflow site (in square miles; $\mathrm{mi}^{2}$ ).

\section{Calculation of Conversion Factors for Turbidity Sensors}

Turbidity sensors were updated from the YSI model 6026 (YSI ${ }_{6026}$ ) to the YSI model 6136 (YSI ${ }_{6136}$ ) sensors in January 2011. YSI ${ }_{6136}$ turbidity sensors were operated alongside the YSI $_{6026}$ turbidity sensors during October 2009 through December 2010. Because of the change in turbidity sensor instrumentation, 1 year of concurrent $\mathrm{YSI}_{6026}$ and $\mathrm{YSI}_{6136}$ hourly turbidity measurements (October 2009 through October 2010) was used to develop a conversion factor. Ordinary least squares regression analyses were performed on the concurrent turbidity measurements to aid in conversion factor selection (Helsel and Hirsch, 2002). A median conversion factor was calculated as the ratio of the $\mathrm{YSI}_{6136}$ sensor value to the $\mathrm{YSI}_{6026}$ sensor value because the median was less likely to be affected by outliers (Rasmussen and others, 2009). The conversion factor was then applied to YSI $_{6026}$-based models without additional modification so the models developed in this report could incorporate turbidity data collected by both instruments.

\section{Results of Continuously Monitored Variables}

Streamflow is one of the key variables that shape the structure and function of stream ecosystems (Allan, 1995). Hourly streamflows ranged from 0 to 8,460 cubic feet per second $\left(\mathrm{ft}^{3} / \mathrm{s}\right)$ during 1999 through 2012; mean streamflow was $129 \mathrm{ft}^{3} / \mathrm{s}$, which was about $12 \mathrm{ft}^{3} / \mathrm{s}$ less than the mean streamflow for the period of record (July 1965-December 2012; table 3). The 10 percent streamflow-separation point used to define base flow and runoff conditions occurred at $208 \mathrm{ft}^{3} / \mathrm{s}$ (fig. $3 A$ ).

Specific conductance, $\mathrm{pH}$, water temperature, dissolved oxygen, and turbidity are described using the hourly continuous data collected at the inflow site during 1999 through 2012 (table 3). The dataset for each constituent was 92 to 97 percent complete depending on the amount of missing hourly values. Specific conductance is an indirect measure of dissolved solids 

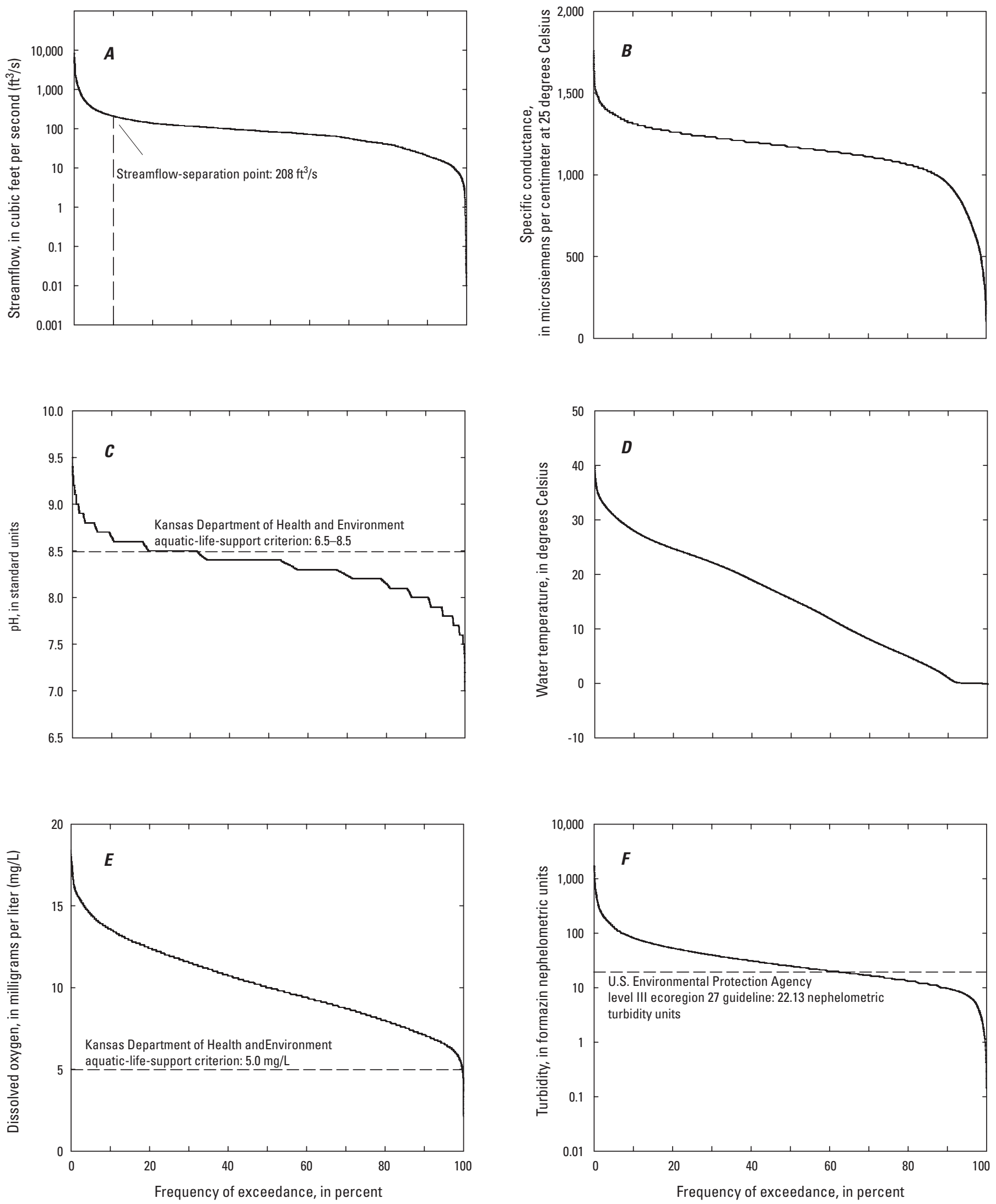

Figure 3. Duration curves for hourly measured $A$, streamflow; $B$, specific conductance; $C$, $\mathrm{pH} ; D$, water temperature; $E$, dissolved oxygen; and $F$, turbidity at the North Fork Ninnescah River upstream from Cheney Reservoir (site 07144780), south-central Kansas, during 1999 through 2012. 
in water (Hem, 1992). Specific conductance ranged from 103 to 1,760 microsiemens per centimeter $(\mu \mathrm{S} / \mathrm{cm})$ at 25 degrees Celsius $\left({ }^{\circ} \mathrm{C}\right)$, and had a mean value of $1,144 \mu \mathrm{S} / \mathrm{cm}$ during 1999 through 2012 (table 3, fig. 3B). Large specific conductance values are likely the result of seepage of groundwater with relatively high dissolved solids concentrations affected by the Salt Plain Formation in the Ninnescah Shale (not shown) that underlies the south-central part of the study area (Gillespie and Hargadine, 1994).

$\mathrm{pH}$ is a measure of the effective hydrogen ion concentration and often is used to evaluate chemical and biological reactions in water; temperature affects the solubility of chemicals in water and biological activity (Hem, 1992). $\mathrm{pH}$ ranged from 7.0 to 9.5 and had a mean of 8.3 (table 3). Kansas aquatic-life-support criteria require that $\mathrm{pH}$ in streams not measure less than 6.5 or more than 8.5 standard units (Kansas Department of Health and Environment, 2008). Measured $\mathrm{pH}$ was never lower than 6.5 , but exceeded 8.5 approximately 19 percent of the time during 1999 through 2012 (fig. 3C). Exceedances primarily occurred during base flow conditions during May through August and likely were caused by increased algal photosynthesis (Graham and others, 2010). Water temperature ranged from -0.2 to $39.8^{\circ} \mathrm{C}$ and had a mean of $15.1^{\circ} \mathrm{C}$ (table 3 , fig. $3 D$ ).

Dissolved oxygen is important for aquatic organisms and concentrations in surface water primarily are related to photosynthesis, respiration, atmospheric reaeration, and water temperature (Lewis, 2006). Dissolved oxygen concentrations ranged from 2.1 to $18.4 \mathrm{mg} / \mathrm{L}$ and had a mean of $10.2 \mathrm{mg} / \mathrm{L}$ (table 3). A Kansas aquatic-life-support criterion requires that dissolved oxygen concentrations are not less than $5.0 \mathrm{mg} / \mathrm{L}$ (Kansas Department of Health and Environment, 2008). Dissolved oxygen concentrations were less than the minimum aquatic-life-support criterion less than 1 percent of the time during 1999 through 2012 (fig. 3E). The lowest dissolved oxygen concentrations (less than $5 \mathrm{mg} / \mathrm{L}$ ) occurred in June, July, and August during periods of increased water temperatures (greater than $20^{\circ} \mathrm{C}$ ) and seasonal low flows.

Turbidity is a measure of the optical properties of water that decrease the passage of light and is caused by suspended and dissolved matter such as clay, silt, finely divided organic material, plankton and other microscopic organisms, organic acids, and dyes (ASTM International, 2003; Anderson, 2005). Turbidity ranged from less than 1.0 to $1,700 \mathrm{FNU}$ and had a mean of 44 FNU (table 3 ). Kansas does not currently (2013) have water-quality criteria for turbidity. U.S. Environmental Protection Agency (USEPA) guidelines for turbidity (based on reference conditions) list 22.13 nephelometric turbidity units (NTU) for level III ecoregion 27 streams, which includes the North Fork Ninnescah River (U.S. Environmental Protection Agency, 2000). Guidelines are non-enforceable goals developed for the protection of water quality, aquatic life, and human health. Turbidity exceeded the USEPA criterion of 22.13 NTU approximately 55 percent of the time during 1999 through 2012 (fig $3 F$ ); these exceedances occurred across the range of streamflows.

\section{Results of Regression Analysis for Selected Constituents}

Relations between in-stream continuous measurements and discrete constituent concentrations were developed and evaluated using ordinary least squares regression. Regression models for 15 constituents developed from data collected during 1997 through 2003 (Christensen and others, 2006) were updated and new models were developed for 5 additional constituents not described in Christensen and others (2006). The updated models were for dissolved solids, sodium, chloride, sulfate, calcium, magnesium, potassium, alkalinity, bicarbonate, total suspended solids, suspended-sediment, total Kjeldahl nitrogen, orthophosphate, total phosphorus, and fecal coliform bacteria. The newly developed models were for nutrients (total nitrogen, nitrate, and organic nitrogen), E. coli bacteria, and total organic carbon. Updated and newly developed models were developed from data collected during 1999 through 2009. Models are shown in table 4 and appendix 2. Models for 10 constituents of interest are presented in table 4 and models for 15 constituents are presented in appendix 2. Model datasets and additional statistical output are presented in Stone and others (2013).

The tobit (appendix 3) and simple linear (appendix 2, table 4) regression model coefficients for organic nitrogen and orthophosphate were either identical or similar. The tobit regression model diagnostics were minimal and did not include information necessary for calculating and publishing constituent concentration information in real time on the USGS website (http://nrtwq.usgs.gov/ks). As such, the simple linear regression models for organic nitrogen and orthophosphate were selected for constituent concentration calculation.

\section{Dissolved Solids, Chloride, and Other Major Ions}

Dissolved solids in surface water primarily consist of the major cations calcium, magnesium, potassium, and sodium, and the anions bicarbonate, chloride, and sulfate. These ions come from decomposing rocks and soils. Concentrations of dissolved solids in stream water may increase because of atmospheric deposition, sewage inputs, industrial effluents, agricultural runoff, and urban runoff (Hem, 1992; Wetzel, 2001). Dissolved solids in the Cheney Reservoir watershed occur naturally as the result of the dissolution of rocks and ancient marine sediments containing large salt deposits (Christensen and Pope, 1997). Dissolved solids often are used as a general indicator of salinity or water quality. Excessively large concentrations of dissolved solids are undesirable in drinking water because of possible physiological effects, strong mineral 


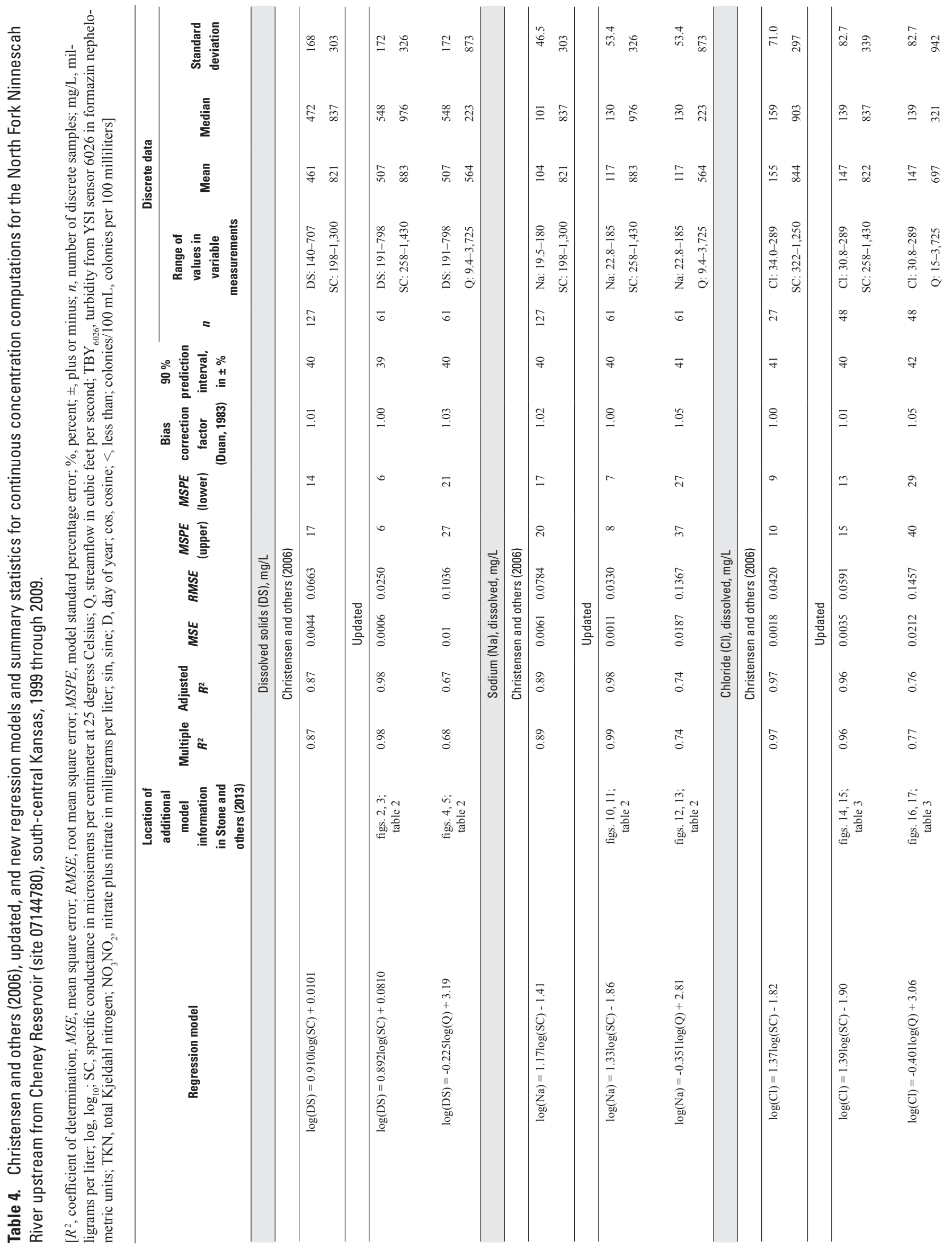




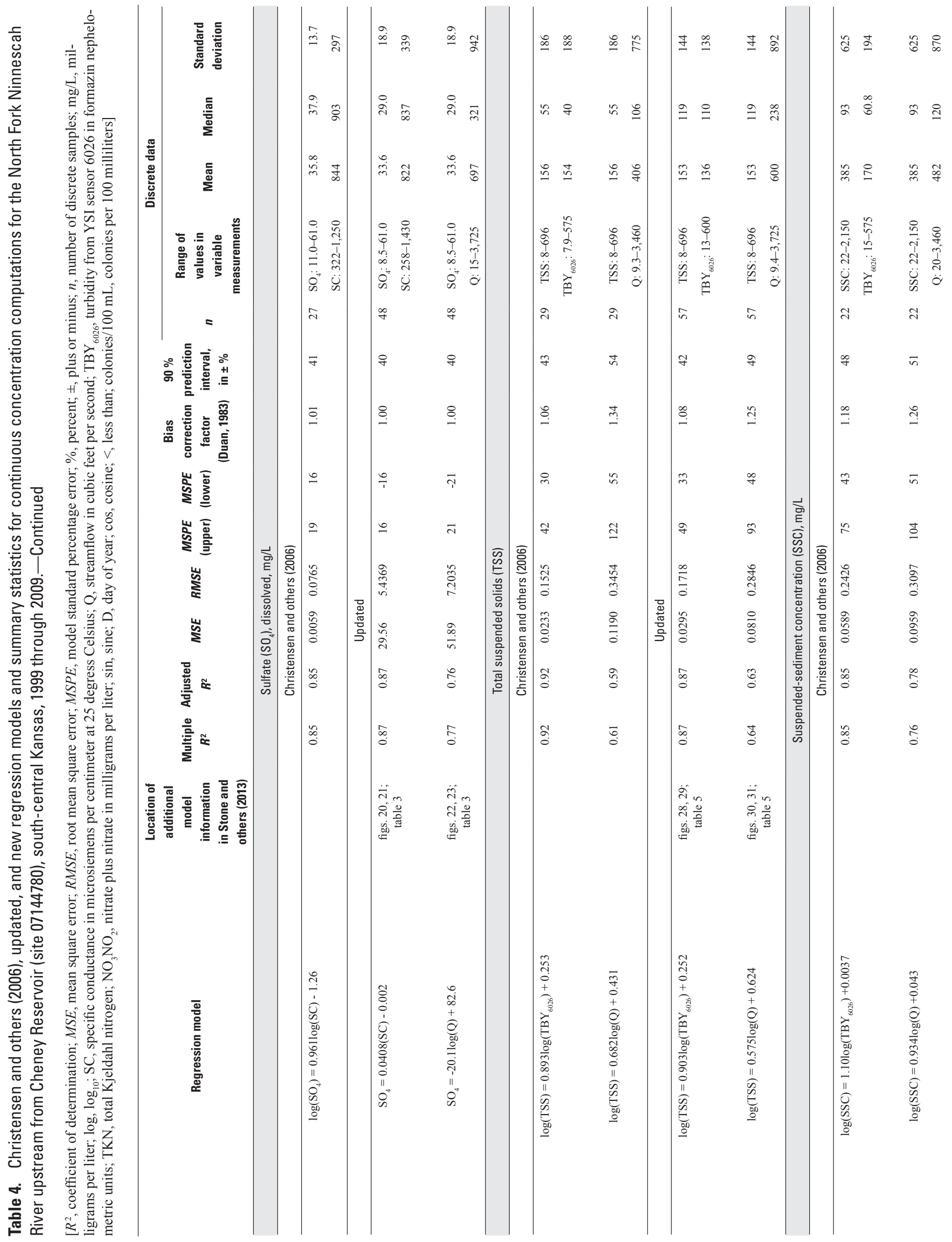




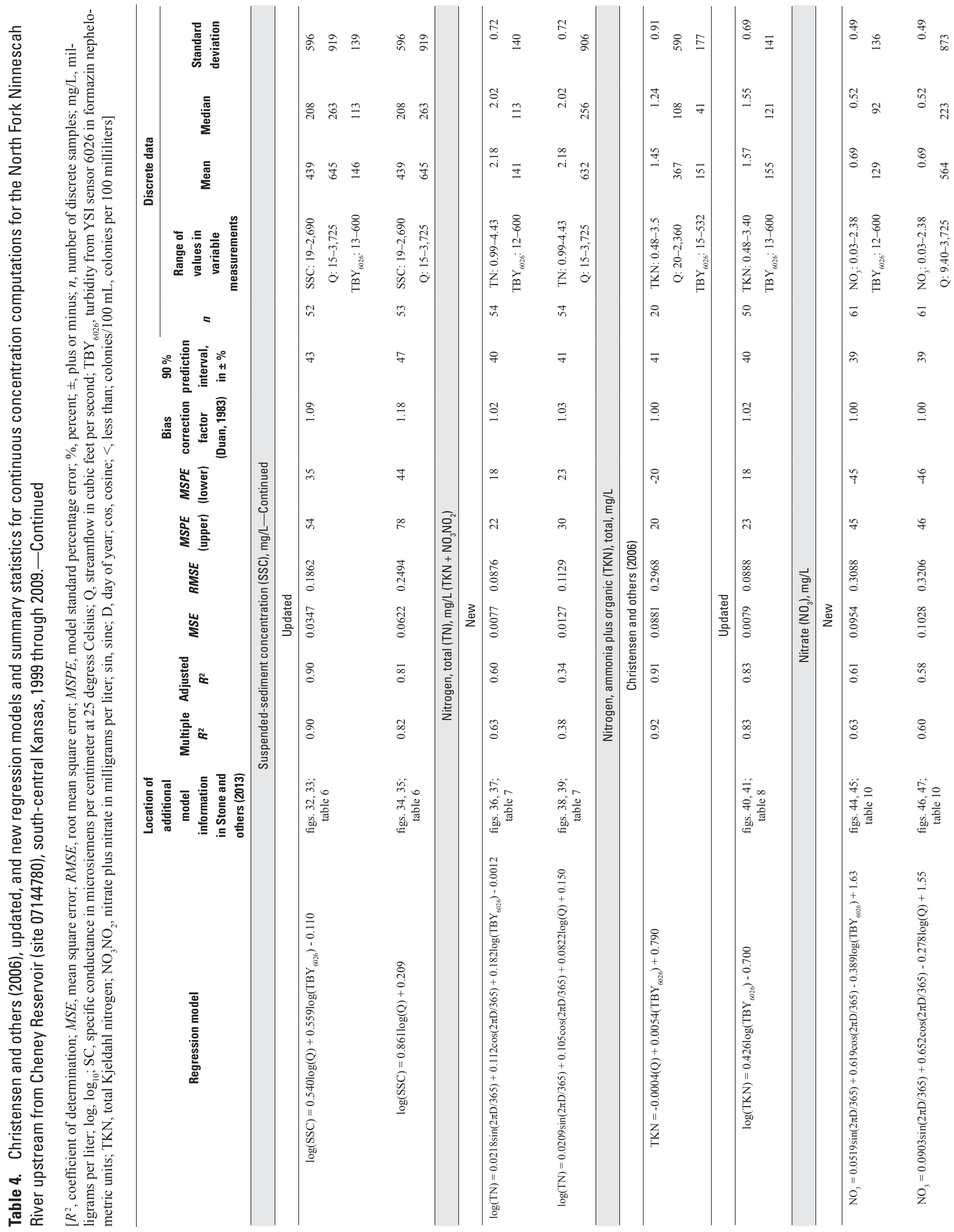




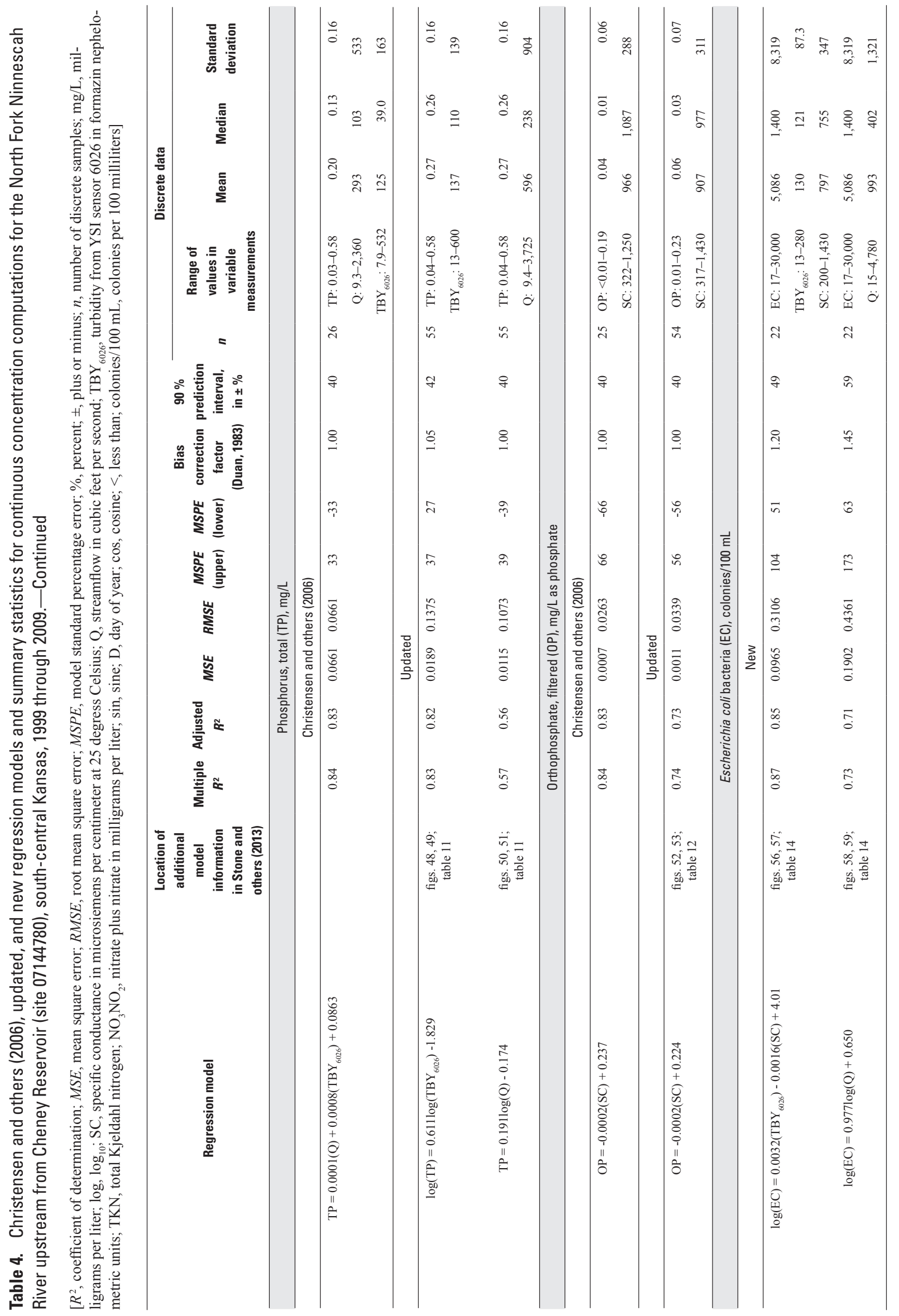


tastes, increased treatment costs, and corrosion in plumbing. Regression relations for dissolved solids, sodium, chloride, and sulfate are described in this section; regression relations for other ions that contribute to dissolved solids are shown in appendix 2 .

Dissolved solids at the inflow site were strongly positively correlated with specific conductance; the updated model reflects this with specific conductance as the only explanatory variable. The general form of the updated model is the same as the original model; however, the regression statistics, including the coefficients, are slightly different because the updated model encompasses a broader range of dissolved solids concentrations and specific conductance values. The updated model explained 11 percent more of the variance in dissolved solids concentrations ( 98 percent) compared to the original model (87 percent; table 4). The model based only on streamflow explained 30 percent less of the variance in dissolved solids concentrations (68 percent) than the specific conductance model. The strong relation between specific conductance and dissolved solids is expected because specific conductance is an indirect measure of the ionized substances in water.

Sodium is present in igneous rocks and sediments and is the most abundant alkali-metal (Hem, 1992). Specific conductance explained the most variance for the old and new sodium models. The updated model form is similar to the original model (table 4). The updated model explained 99 percent of the variance in sodium concentrations versus 89 percent in the original model (table 4). The model based only on streamflow explained 25 percent less variance than the specific conductance-based model.

Chloride occurs naturally in various rock types, generally in low concentrations and most often as an impurity (Hem, 1992). Potential anthropogenic sources of chloride in streamwater generally are agricultural and industrial runoff and wastewater treatment facility discharges. Certain forms of chloride also are major components of road deicers. Chloride is a charged ionic species and the model shows a positive relation between chloride and specific conductance. The updated model coefficients for chloride are similar to the original model and specific conductance is the only explanatory variable for both models (table 4). The updated and the original model explained about the same amount of chloride concentration variance (96 percent for the updated model and 97 percent for the original model). Streamflow explained 19 percent less variance than specific conductance (77 percent).

Rock weathering, oxidation of sulfide minerals, and biological processes are natural sources of sulfate in surface water (Hem, 1992). Atmospheric deposition from the combustion of coal and petroleum products and irrigation return flows are the main anthropogenic sources of sulfate. Sulfate is a charged ionic species and it was positively correlated to specific conductance. Sulfate was correlated with specific conductance in the original and updated models; the updated model explained 87 percent of the variance in sulfate concentrations and the original model explained 85 percent (table 4). The streamflow-based model explained 10 percent less variance than the specific conductance-based model (77 percent).

\section{Total Suspended Solids and Sediment}

Total suspended solids and suspended-sediment concentration are the two analytes typically used to describe concentrations of suspended solid-phase material in surface water. Although the terms often are used interchangeably, the laboratory analytical methods differ, and therefore the measured concentrations differ as well. Total suspended solids represent suspended solid material and may consist of organic or inorganic materials. They originate from sources such as algae, decaying vegetation, agricultural and urban runoff, municipal and industrial discharges, and physical degradation of geologic formations. The amount of total suspended solids in a medium is equal to the dry weight of organic and inorganic solids filtered from a subsample of the original sample. Suspended solids provide a medium for the accumulation and transport of other constituents of concern, such as phosphorus and bacteria. Suspended-sediment concentration is the measure of the dry weight of the organic and inorganic sediment in a full sample volume of a water-sediment mixture (Guy, 1969). Suspended sediment may consist of clay, silt, sand, or organic material.

Sediment originates primarily from surface soils and geology, channel bank erosion, and streambed sediment that is resuspended during high-flow events. Suspended particulates provide attachment sites for nutrients, organic compounds, and other potential contaminants. Turbidity, caused by suspended and dissolved material, often is used as a surrogate for suspended solids and sediment.

Turbidity is a physical property related to total suspended solids and is an indicator of sediment and other solid material transported in streams. Turbidity was related to total suspended solids in the original and updated models; the updated model explained about 5 percent less variance ( 87 percent) in total suspended solids concentration than the original model (92 percent; table 4). Streamflow also was related to total suspended solids but the streamflow model explained 23 percent less variance than the turbidity model (64 percent; table 4).

Turbidity is a suitable surrogate for the estimation of continuous suspended-sediment concentration and was used by Christensen and others (2006); however, unlike the original model, the updated suspended-sediment concentration model also included streamflow as an explanatory variable (table 4). The updated model that included turbidity and streamflow explained 90 percent of the variance in suspended-sediment concentrations whereas the turbidity-based original model explained 85 percent of the variance. The updated suspendedsediment concentration model using only streamflow explained 8 percent less variance than the model that included turbidity and streamflow (table 4). 


\section{Nutrients}

Streams receive nutrients from upstream sources, terrestrial runoff, groundwater, and the atmosphere. Nutrients, including species of nitrogen and phosphorus, are necessary for plant and animal growth but can lead to eutrophication, algal blooms, low dissolved oxygen, fish kills, and taste-andodor problems when present in excess amounts. Nutrients, particularly nitrogen and phosphorus, have been identified as a primary source of water-quality degradation in Kansas and the Nation (Kansas Department of Health and Environment, 2004a; U.S. Environmental Protection Agency, 2000, 2006). Point sources of nutrients include municipal and industrial wastewater effluent and storm sewer discharge. The Cheney Reservoir watershed has very few point sources of pollution. Nonpoint sources of nutrients include livestock, crop fertilizers, and urban runoff. Nutrients in the Cheney Reservoir watershed generally originate from nonpoint sources and likely are related to agricultural activities (Christensen and Pope, 1997). Regression relations for total nitrogen, total Kjeldahl nitrogen, nitrate, total phosphorus, and orthophosphate are described in this section; regression relations for other nutrients are shown in appendix 2.

Nitrogen occurs as ammonia, nitrite, nitrate, and as part of organic compounds. Most algae utilize dissolved forms of inorganic nitrogen (Hem, 1992). Nitrate is the form of nitrogen most easily used by plants and algae and is the most common ion in many oxygen-rich waters because the nitrite ion is easily oxidized. The large increase in amounts of nitrogen fertilizers used on agricultural land in recent decades has prompted considerable concern about increases in nitrate concentrations in surface and groundwater (Hem, 1992). Excessive nitrate concentrations in drinking water can pose adverse health effects on humans, such as methemoglobinemia, a condition also known as blue baby syndrome. This condition restricts the oxygencarrying capacity of blood and may be fatal (Walton, 1951).

The newly developed total nitrogen (total Kjeldahl nitrogen plus nitrate plus nitrite) model includes turbidity and a seasonal component (expressed as sine and cosine variables) as explanatory variables (table 4). Because of the predominately agricultural land use in the watershed, total nitrogen likely had a seasonal component because of the timing of fertilizer application. Sixty percent of the variance in total nitrogen concentration was explained by the turbidity-and-season-based model. A total nitrogen model based on streamflow and a seasonal component explained 26 percent less variance than the turbidity-based model (34 percent).

Total Kjeldahl nitrogen (ammonia plus organic nitrogen) comprised an average of 68 percent (range: 17-99 percent) of the total nitrogen concentration in discrete samples. The original and updated total Kjeldahl nitrogen model had turbidity as an explanatory variable (table 4 ). The updated model explained about 8 percent less ( 83 percent) of the variance in total Kjeldahl nitrogen concentration than the original model (91 percent).
The newly developed nitrate model had turbidity and a seasonal component as explanatory variables (table 4). Sixty-one percent of the variance in nitrate concentration was explained by the turbidity-and-season-based model. A streamflow-and-season-based model explained about 3 percent less variance ( 58 percent) in nitrate concentration than the turbidityand-season-based model. Nitrate was negatively correlated with turbidity and streamflow. Streamflow-related runoff events increase turbidity and likely diluted the ambient nitrate.

Phosphorus is introduced into the environment by the breakdown of soil and rock minerals. Most phosphorus in surface water is bound organically, and much of the organic phosphorus fraction is in the particulate phase of living cells, primarily algae (Wetzel, 2001). Sources of phosphorus in the North Fork Ninnescah River watershed include inorganic phosphates from fertilizer, manure from animal production, and runoff. Turbidity was an explanatory variable in the original and updated total phosphorus models, likely because phosphorus adsorbs to suspended sediment and other particulate matter. The updated and original models explained 83 percent of the variance in total phosphorus concentrations (table 4). The newly developed model for total phosphorus based on streamflow alone explained about 26 percent less variance than the total phosphorus model based on turbidity (57 percent). Orthophosphate represented an average of about 27 percent of total phosphorus concentration in discrete samples. The original and updated models included specific conductance as the explanatory variable. The original model explained about 10 percent more variance ( 84 percent) than the updated model (74 percent; table 4).

\section{Escherichia coli Bacteria}

E. coli are a type of coliform bacteria that are specific to fecal material from humans and other homeothermic animals and are a common type of bacteria used as an indicator of pathogens in surface water. E. coli is carried into water from septic systems, sewer pipes, wastewater treatment plants, farms, yards, wildlife, pets, feedlots, and pastures. E. coli bacteria indicate the potential for pathogens that can cause diarrhea, headaches, nausea, and abdominal cramping and may pose a more serious health risk for younger individuals and people with compromised immune systems [National Research Council (U.S.), 2004]. Suspended material in streams provide a medium for bacterial accumulation and transport. As such, turbidity can be an important surrogate for the estimation of $E$. coli densities. The newly developed $E$. coli model included turbidity and specific conductance as explanatory variables and explained 85 percent of the variance in $E$. coli densities. $E$. coli had a positive relation with turbidity and a negative relation with specific conductance because fecal coliform bacteria sources are associated with runoff events, which generally increase turbidity and decrease specific conductivity in streamwater. A model based on streamflow alone explained 12 percent 
less variance ( 73 percent; table 4 ) than the model based on turbidity and specific conductance.

\section{New Models and Changes in Updated Models}

Total nitrogen, nitrate, organic nitrogen, E. coli bacteria, and total organic carbon (table 4; appendix 2) models were newly developed for this report. Additional data collection over a wider range of hydrological conditions facilitated the development of these models. The nitrate model is particularly important because it allows for comparison to Cheney Reservoir Task Force goals.

In general, model forms and the amount of variance explained by the models was similar between the original (Christensen and others, 2006) and updated models. The model forms for most updated models remained unchanged. The two exceptions were suspended sediment concentration and total Kjeldahl nitrogen. The updated suspended-sediment concentration model includes streamflow as an additional explanatory variable and the updated total Kjeldahl model excludes streamflow as an additional explanatory variable (table 4). The amount of variance explained by the updated models decreased by 10 percent or less relative to the original models. Variance explained increased for the updated dissolved solids, sodium, sulfate, and suspended-sediment concentration models and decreased for the updated chloride, total suspended solids, total Kjeldahl nitrogen, total phosphorus, and orthophosphate models.

\section{Turbidity, YSI Model 6026 and 6136 Sensors}

Regression models were developed in this report and by Christensen and others (2006) using YSI $026_{\text {t }}$ turbidity sensor data to compute concentrations or densities of physical, chemical, and biological water properties, and associated loads and yields at the inflow site. Because of the change in turbidity instrumentation fromYSI ${ }_{6026}$ to YSI $_{6136}$ sensors in January 2011, the regression models that were developed using $\mathrm{YSI}_{6026}$ data require modification. The computation of a conversion factor allows the $\mathrm{YSI}_{6026}$ sensor regression models to accommodate turbidity measurements from the $\mathrm{YSI}_{6136}$ sensor.

The ordinary least squares regression shows the relation between the YSI $_{6026}$ and $\mathrm{YSI}_{6136}$ turbidity sensors and explains 96 percent of the variance in turbidity readings (fig. 4, appendix 4). YSI ${ }_{6136}$ sensor measurements were on average 27 percent lower than YSI $_{6026}$ measurements. The ratios of the $\mathrm{YSI}_{6136}$ sensor values to theYSI ${ }_{6026}$ sensor values ranged from 0.19 to 3.92 and had a median of 0.68 (appendix 4). To convert YSI ${ }_{6026}$ turbidity measurements to $\mathrm{YSI}_{6136}$ turbidity measurements at the inflow site, the $\mathrm{YSI}_{6026}$ turbidity measurement should be multiplied by the conversion factor of 0.68 . The original and newly developed models from this report are shown in appendixes 5 and 6 in addition to converted models that should be used to calculate concentrations when turbidity is measured using the YSI $_{6136}$ turbidity sensor at the inflow site.

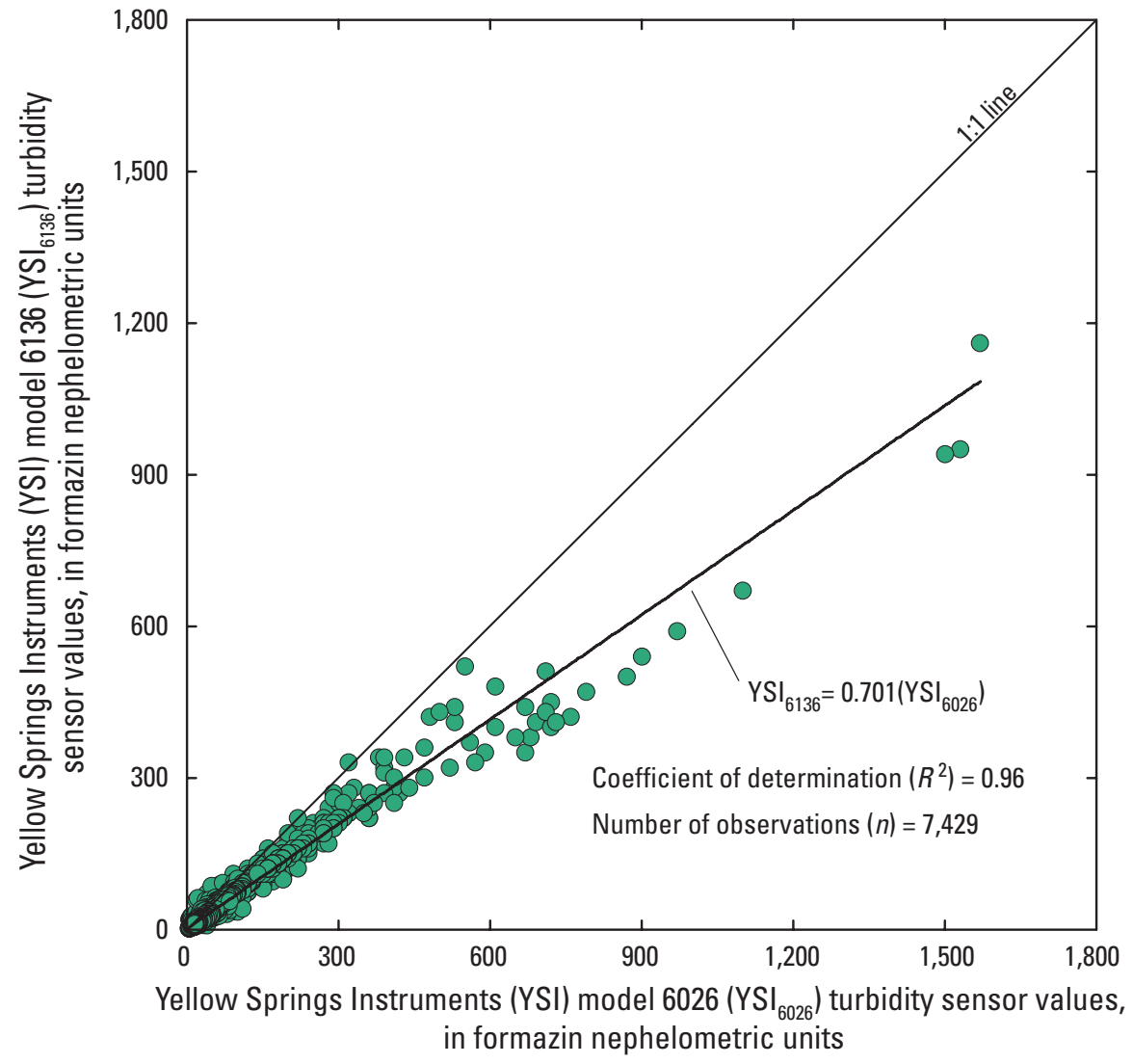

Figure 4. Relation between Yellow Springs Instruments (YSI) model 6026 (YSI ${ }_{6026}$ ) and $\mathrm{YSI}$ model 6136 (YSI ${ }_{6136}$ ) turbidity sensor values at the North Fork Ninnescah River upstream from Cheney Reservoir (site 07144780), south-central Kansas, October 2009 through October 2010. 


\section{Computed Constituent Concentrations, Loads, and Yields}

Hourly constituent concentrations were computed using continuous data from January 1999 through December 2012 with the updated and newly developed models from table 4. Concentration data were useful for evaluating the waterquality conditions of the North Fork Ninnescah River as well as calculating constituent loads. Load is the mass quantity of a constituent transported by the river during a given period of time.

\section{Dissolved Solids, Chloride, and Other Major Ions}

The models using specific conductance as explanatory variables (table 4) were used for ion concentration computations when specific conductance data were available. Ninetythree percent of the hourly specific conductance values were available during 1999 through 2012. When specific conductance data were not available the streamflow-based models (table 4) were used for constituent concentration computations. Comparisons of ambient water-quality constituents with drinking-water guidelines or advisories in this section of the report provide an indication of the water quality of water flowing into Cheney Reservoir.

The USEPA has established National Secondary Drinking Water Regulations that set nonmandatory water-quality standards. The USEPA does not enforce these secondary maximum contaminant levels (SMCLs); they were established as guidelines to assist public water-supply systems in managing their drinking water for aesthetic considerations such as taste, color, and odor (U.S. Environmental Protection Agency, 2005). The USEPA (2005) has established a SMCL for dissolved solids in drinking water of $500 \mathrm{mg} / \mathrm{L}$. Computed dissolved solids ranged from 12.8 to $3,360 \mathrm{mg} / \mathrm{L}$ (mean: $652 \mathrm{mg} / \mathrm{L}$; table 5). Based on the computed hourly dissolved solids concentrations, the USEPA SMCL of 500 $\mathrm{mg} / \mathrm{L}$ was exceeded about 93 percent of the time during 1999 through 2012 (fig. 5A).

The USEPA (1995) has established a Drinking Water Advisory (DWA) for sodium of $20 \mathrm{mg} / \mathrm{L}$ for individuals on a 50 milligrams per day $(\mathrm{mg} / \mathrm{d})$ restricted sodium diet. Regression-computed sodium concentrations ranged from 6.54 to $2,172 \mathrm{mg} / \mathrm{L}$, with a mean of $168 \mathrm{mg} / \mathrm{L}$ (table 5). Based on the computed hourly sodium concentrations, the USEPA DWA of $20 \mathrm{mg} / \mathrm{L}$ was exceeded nearly 100 percent of the time during 1999 through 2012 (fig. 5B). The mean sodium concentration of $168 \mathrm{mg} / \mathrm{L}$ was approximately 19 times higher than the North American average for river water, which is approximately $9 \mathrm{mg} / \mathrm{L}$ (Wetzel, 2001). High sodium concentrations likely are the result of seepage of groundwater affected by the Salt Plain Formation in the Ninnescah Shale (not shown) that underlies the south-central part of the study area (Gillespie and Hargadine, 1994). The groundwater with naturally elevated sodium concentrations also caused the relatively high dissolved solids concentrations in the North Fork Ninnescah River.

Chloride is an ion of interest because of the aquatic-life criteria established by KDHE and USEPA. The USEPA has an SMCL for chloride in drinking water of $250 \mathrm{mg} / \mathrm{L}$ (U.S. Environmental Protection Agency, 2005) and KDHE has established an aquatic-life-support criterion for chloride of $860 \mathrm{mg} / \mathrm{L}$ (Kansas Department of Health and Environment, $2004 b)$. The mean computed hourly chloride concentration was $234 \mathrm{mg} / \mathrm{L}$ and ranged from 7.88 to $4,482 \mathrm{mg} / \mathrm{L}$ (table 5). Based on the computed hourly chloride concentrations, the USEPA SMCL for chloride $(250 \mathrm{mg} / \mathrm{L})$ was exceeded about 26 percent of the time during 1999 through 2012 (fig. 5C), generally during winter and lower flows likely because of road salt application and contribution of chloride by groundwater. The KDHE aquatic-life-support criterion for chloride (860 $\mathrm{mg} / \mathrm{L}$ ) was exceeded less than 1 percent of the time during extremely low flows in July and August 2012.

The USEPA has an SMCL for sulfate in drinking water of $250 \mathrm{mg} / \mathrm{L}$ (U.S. Environmental Protection Agency, 2005). The mean computed sulfate concentration was $46.9 \mathrm{mg} / \mathrm{L}$ and ranged from 4.20 to $90.7 \mathrm{mg} / \mathrm{L}$ (table 5). Based on the computed hourly sulfate concentrations, the USEPA SMCL for sulfate $(250 \mathrm{mg} / \mathrm{L})$ was never exceeded during 1999 through 2012 (fig. 5D).

\section{Total Suspended Solids and Sediment}

The model using turbidity as the explanatory variable (table 4) was used for suspended solids concentration computations when turbidity data were available. Ninety-three percent of the hourly turbidity values were available during 1999 through 2012. When turbidity data were not available the streamflow-based total suspended solids model (table 4) was used for concentration computations.

Based on computed hourly concentrations, total suspended solids ranged from less than 1 to $1,595 \mathrm{mg} / \mathrm{L}$ (mean: $54 \mathrm{mg} / \mathrm{L}$ ) during 1999 through 2012 (table 5). Annual mean total suspended solids concentrations were largest in 2002 (86 mg/L) and smallest in $2012(23 \mathrm{mg} / \mathrm{L})$, corresponding with the largest (80 FNU in 2002) and smallest (18 FNU in 2012) annual mean turbidities (table 6). The smallest annual mean total suspended solids concentration ( $23 \mathrm{mg} / \mathrm{L})$ also corresponds to the smallest annual mean streamflow $\left(45 \mathrm{ft}^{3} / \mathrm{s}\right)$.

The total suspended solids load for 1999 through 2012 was 174,031 tons (table 7). The smallest annual total suspended solids load was 1,457 tons in 2011 , corresponding to the second-smallest annual mean streamflow and streamflow load (57 ft $\mathrm{ft}^{3} / \mathrm{s}$ and 41,114 acre feet, respectively). The largest annual total suspended solids load was 23,620 tons in 2010, corresponding to the largest annual mean streamflow and streamflow load $\left(215 \mathrm{ft}^{3} / \mathrm{s}\right.$ and 155,856 acre feet, respectively; tables 6 , 7; figs. $6 A, B)$. 
Table 5. Summary of hourly statistics for selected water-quality constituents computed with updated regression models and continuously measured variables at the North Fork Ninnescah River upstream from Cheney Reservoir (site 07144780), southcentral Kansas, 1999 through 2012.

[Continuous real-time water quality data are available on the U.S. Geological Survey National Real-Time Water-Quality Web site (http://nrtwq.usgs. gov/ks); $n$, number of measurements; $\mathrm{mg} / \mathrm{L}$, milligrams per liter; <, less than; col/100 mL, colonies per 100 milliliters]

\begin{tabular}{lccccc}
\hline \multicolumn{1}{c}{ Continuous variable } & $\boldsymbol{n}$ & Minimum & Maximum & Mean & Median \\
\hline Dissolved solids (mg/L) & 112,692 & 12.8 & 3,360 & 652 & 657 \\
Sodium (mg/L) & 122,736 & 6.54 & 2,172 & 168 & 166 \\
Chloride (mg/L) & 122,736 & 7.88 & 4,482 & 234 & 230 \\
Sulfate (mg/L) & 122,736 & 4.20 & 90.7 & 46.9 & 47.7 \\
Total suspended solids (mg/L) & 122,696 & $<1$ & 1,595 & 54 & 34 \\
Suspended sediment (mg/L) & 122,627 & $<1$ & 3,737 & 88 & 54 \\
Total nitrogen (mg/L) & 122,696 & 0.75 & 4.29 & 1.87 & 1.84 \\
Nitrate (mg/L) & 122,501 & $<0.01$ & 2.27 & 1.08 & 1.10 \\
Total phosphorus (mg/L) & 121,856 & $<0.01$ & 1.46 & 0.14 & 0.11 \\
Escherichia coli (col/100 mL) & 122,696 & $<1$ & $1,900,000,000$ & 290,000 & 190 \\
\hline
\end{tabular}

The model using turbidity and streamflow as explanatory variables (table 4 ) was used for suspended-sediment concentration computations when turbidity values were available. Ninety-three percent of the hourly turbidity and discharge values were available during 1999 through 2012 (table 3 ). When turbidity values were not available, the streamflow-based suspended-sediment concentration model (table 4) was used. The duration curve for suspended-sediment concentrations is shown in figure $5 F$. Suspended-sediment concentrations for 1999 through 2012 ranged from less than 1 $\mathrm{mg} / \mathrm{L}$ to $3,737 \mathrm{mg} / \mathrm{L}$ (mean: $88 \mathrm{mg} / \mathrm{L}$; table 5). Annual mean suspended-sediment concentrations ranged from $30 \mathrm{mg} / \mathrm{L}$ in 2012 to $123 \mathrm{mg} / \mathrm{L}$ in 2009, corresponding to the smallest (45 $\left.\mathrm{ft}^{3} / \mathrm{s}\right)$ and second-largest $\left(204 \mathrm{ft}^{3} / \mathrm{s}\right)$ annual mean streamflows (table 6). Suspended-sediment load for 1999 through 2012 was 518,321 tons (table 7). Suspended-sediment load ranged from 2,455 tons in 2011 to 114,959 tons in 2010, corresponding to the second-smallest $\left(57 \mathrm{ft}^{3} / \mathrm{s}\right)$ and largest $\left(215 \mathrm{ft}^{3} / \mathrm{s}\right)$ annual mean streamflows, respectively (table 7; fig. 6C).

\section{Nutrients}

The model using turbidity as a surrogate (table 4) was used for total nitrogen concentration computations when turbidity values were available. Ninety-three percent of the hourly turbidity values during 1999 through 2012 were available (table 3). The streamflow-based total nitrogen model (table 4) was used when turbidity values were not available. Based on hourly concentrations, mean total nitrogen during 1999 through 2012 was $1.87 \mathrm{mg} / \mathrm{L}$ (range: $0.75 \mathrm{mg} / \mathrm{L}$ to $4.29 \mathrm{mg} / \mathrm{L}$; table 5). The USEPA total nitrogen guideline for level III ecoregion 27 streams is $0.84 \mathrm{mg} / \mathrm{L}$ (U.S. Environmental Protection Agency, 2002). The USEPA recommended total nitrogen guideline of $0.84 \mathrm{mg} / \mathrm{L}$ was exceeded nearly
100 percent of the time from January 1999 through December 2012 (fig. 7A).

Annual mean total nitrogen concentration ranged from $1.79 \mathrm{mg} / \mathrm{L}$ in 2006 to $2.04 \mathrm{mg} / \mathrm{L}$ in 2001 and did not vary substantially among years (table 6 ). The total nitrogen load for 1999 through 2012 was 3,098 tons (table 7). Annual total nitrogen loads ranged from 88 tons in 2011 and 2012 to 347 tons in 2010, corresponding to the smallest and largest annual mean streamflows (tables 6, 7; fig. 6D).

The model using turbidity as a surrogate (table 4 ) was used for nitrate concentration computations when turbidity values were available. Ninety-three percent of hourly turbidity values were available during 1999 through 2012 (table 3). The discharge-based nitrate model was used (table 4) to compute nitrate concentrations when turbidity values were not available. The Federal maximum contaminant level (MCL) for nitrate in drinking water is $10 \mathrm{mg} / \mathrm{L}$ as nitrogen (U.S. Environmental Protection Agency, 2009). An MCL is the highest permissible level (on an annual basis) of a contaminant in water that is delivered to any user of a public water system. The $10 \mathrm{mg} / \mathrm{L}$ nitrate MCL was never exceeded during 1999 through 2012 (table 5, fig. 7B).

Based on computed hourly nitrate concentrations, mean nitrate was $1.08 \mathrm{mg} / \mathrm{L}$ for all flow conditions and ranged from less than $0.01 \mathrm{mg} / \mathrm{L}$ to $2.27 \mathrm{mg} / \mathrm{L}$ during 1999 through 2012 (table 5). Annual mean nitrate concentrations ranged from $1.00 \mathrm{mg} / \mathrm{L}$ in 2001 to $1.25 \mathrm{mg} / \mathrm{L}$ in 2012 (table 6). The nitrate load for 1999 through 2012 was 1,361 tons and ranged from 56 tons in 2006 to 145 tons in 2009, which corresponded to the third-lowest and second-highest annual mean streamflows and annual streamflow volumes (tables 6, 7; figs. 6A,E).

The model using turbidity as a surrogate (table 4 ) was used for total phosphorus concentration computations when turbidity values were available. Ninety-three percent of the hourly turbidity values during 1999 through 2012 were 

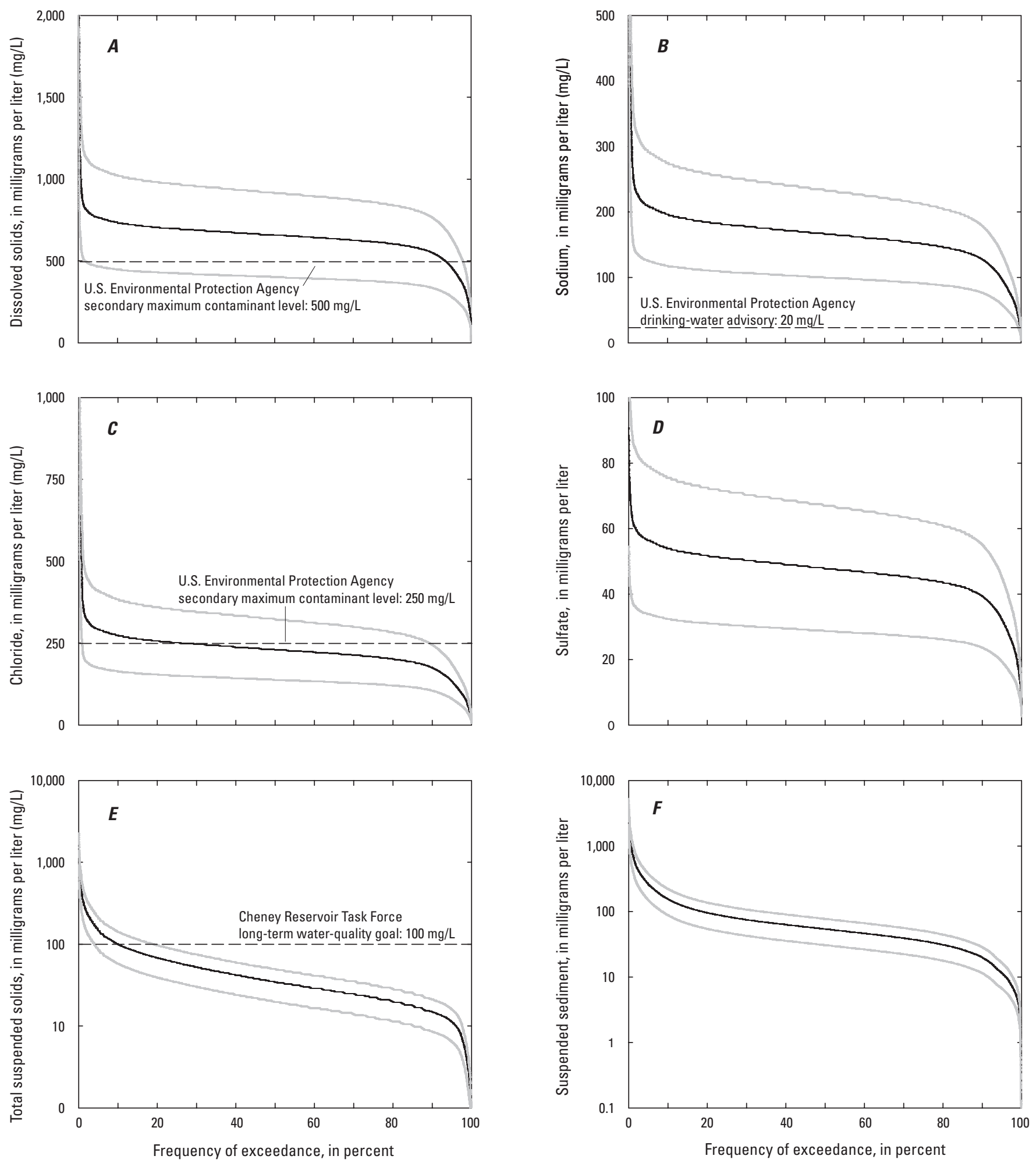

EXPLANATION

Duration curve

90-percent prediction interval

Figure 5. Duration curves for hourly computed $A$, dissolved solids; $B$, sodium; $C$, chloride; $D$, sulfate; $E$, total suspended solids; and $F$, suspended sediment at the North Fork Ninnescah River upstream from Cheney Reservoir (site 07144780), south-central Kansas, during 1999 through 2012. 
Table 6. Annual means for continuously measured and computed constituents at the North Fork Ninnescah River upstream from Cheney Reservoir (site 07144780), south-central Kansas, during 1999 through 2012.

[Continuous real-time water quality data are available on the U.S. Geological Survey National Real-Time Water-Quality Web site (http://nrtwq.usgs.gov/ks); $\mathrm{ft}^{3} / \mathrm{s}$, cubic feet per second; $\mu \mathrm{S} / \mathrm{cm}$, microsiemens per centimeter at 25 degrees Celsius; ${ }^{\circ} \mathrm{C}$, degrees Celsius; mg/L, milligrams per liter; FNU, formazin nephelometric units]

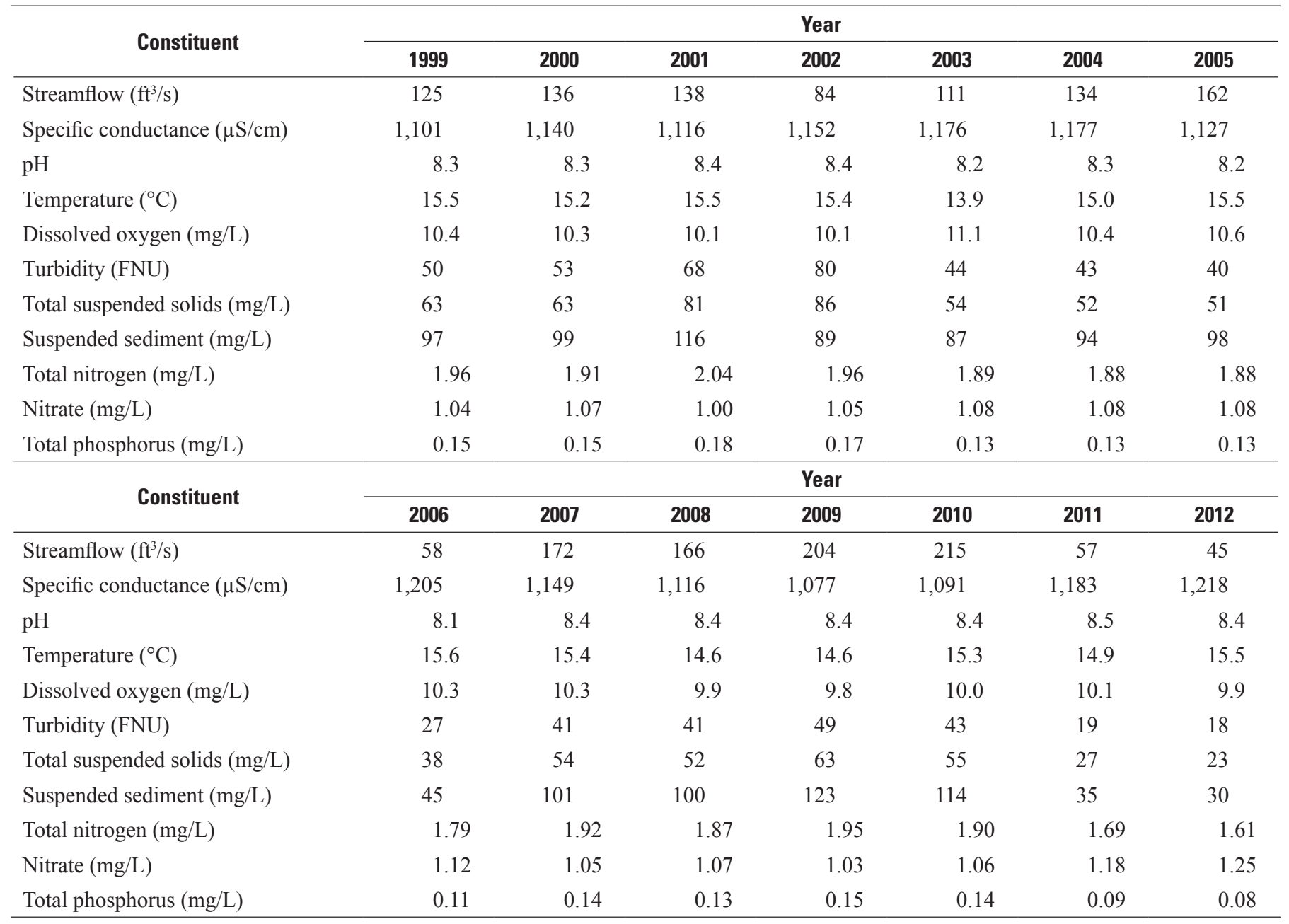

available (table 3). When turbidity values were not available, the streamflow-based total phosphorus model (table 4) was used to compute hourly total phosphorus concentrations. The USEPA total phosphorus guideline for level III ecoregion 27 streams is $0.09 \mathrm{mg} / \mathrm{L}$ (U.S. Environmental Protection Agency, 2002). Based on hourly concentrations, mean total phosphorus concentration during 1999 through 2012 was 0.14 $\mathrm{mg} / \mathrm{L}$ (range: less than $0.01 \mathrm{mg} / \mathrm{L}$ to $1.46 \mathrm{mg} / \mathrm{L}$; table 5 ). The USEPA level III ecoregion 27 total phosphorus guideline of $0.09 \mathrm{mg} / \mathrm{L}$ was exceeded approximately 67 percent of the time from 1999 through 2012 (fig. 7C). Annual mean total phosphorus concentrations ranged from $0.08 \mathrm{mg} / \mathrm{L}$ in 2012 to 0.18 $\mathrm{mg} / \mathrm{L}$ in 2001 (table 6). The total phosphorus load for 1999 through 2012 was 328 tons (table 7). The total phosphorus load ranged from 5 tons in 2011 and 2012 to 43 tons in 2010. These minimum and maximum annual loads correspond to the smallest and largest yearly streamflow volumes, respectively (table 7; figs. 6A,F).

\section{Escherichia coli Bacteria}

The models using turbidity and specific conductance as explanatory variables (table 4) were used for E. coli concentration computations when these data were available. Ninetythree percent of the hourly turbidity and specific conductance values were available during 1999 through 2012 (table 3). When turbidity and specific conductance data were not available the streamflow-based models (table 4) were used to compute E. coli densities.

The State of Kansas established surface-water recreational-use E. coli criteria in 2004 for streams with flows of at least $1 \mathrm{ft}^{3} / \mathrm{s}$. The primary contact criterion for these publicly accessible Kansas streams is that the geometric mean of at least five samples, collected during separate 24-hour periods within a 30-day period, should not exceed 262 colony forming units per 100 milliliters $(\mathrm{mL})$ during April 1 through October 31 of each year, and 2,358 colony forming units per $100 \mathrm{~mL}$ 
Table 7. Computed annual loads and yields for selected constituents at the North Fork Ninnescah River upstream from Cheney Reservoir (site 07144780), south-central Kansas, during 1999 through 2012.

[All loads and yields are estimated. With the exception of streamflow, loads are expressed in tons and yields are expressed in pounds per square mile. Streamflow is expressed in acre feet and acre feet per acre for loads and yields, respectively.]

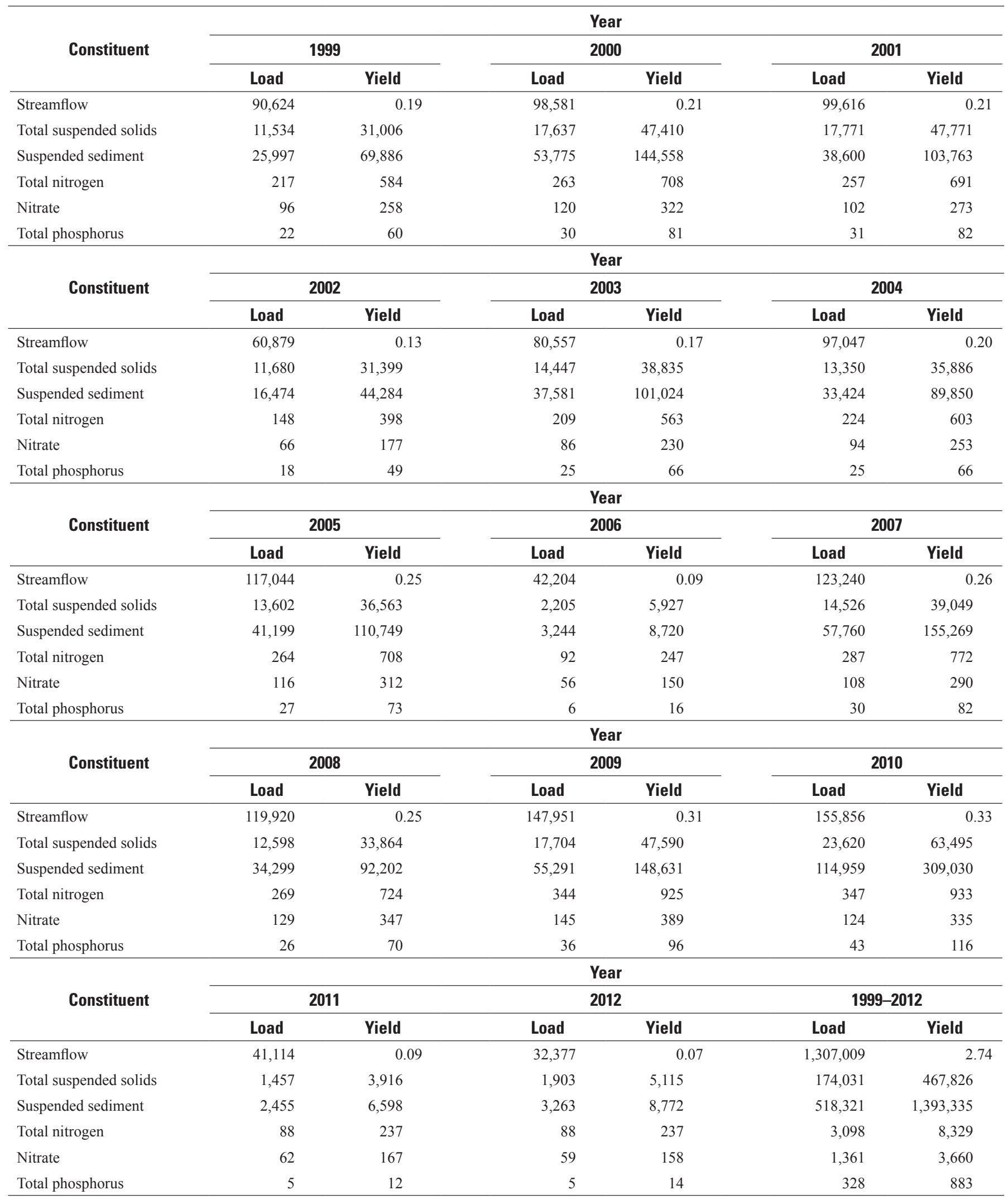



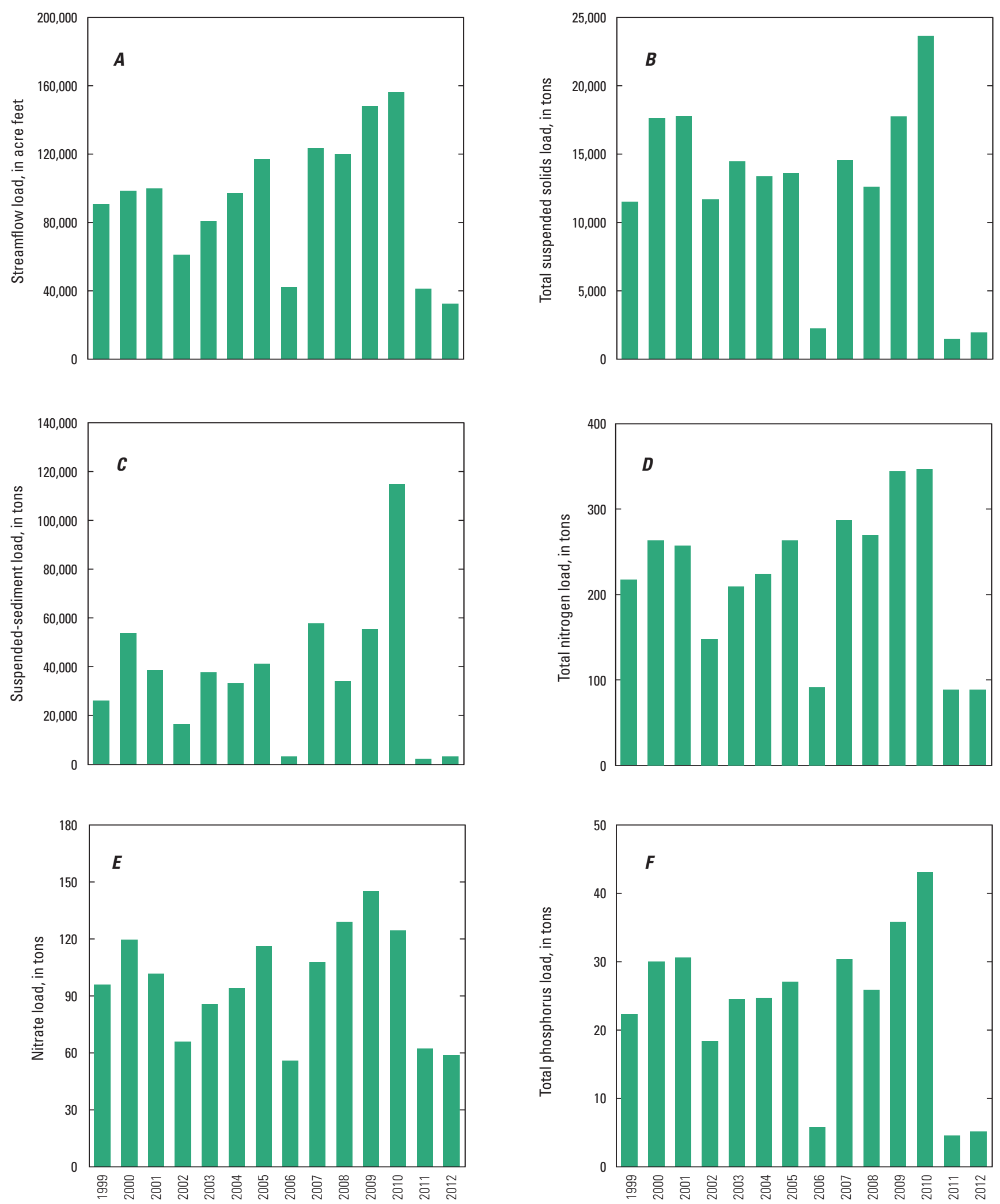

Figure 6. Computed annual $A$, streamflow; $B$, total suspended solids; $C$, suspended-sediment; $D$, total nitrogen; $E$, nitrate; and $F$, total phosphorus loads at the North Fork Ninnescah River upstream from Cheney Reservoir (site 07144780), south-central Kansas, during 1999 through 2012. 

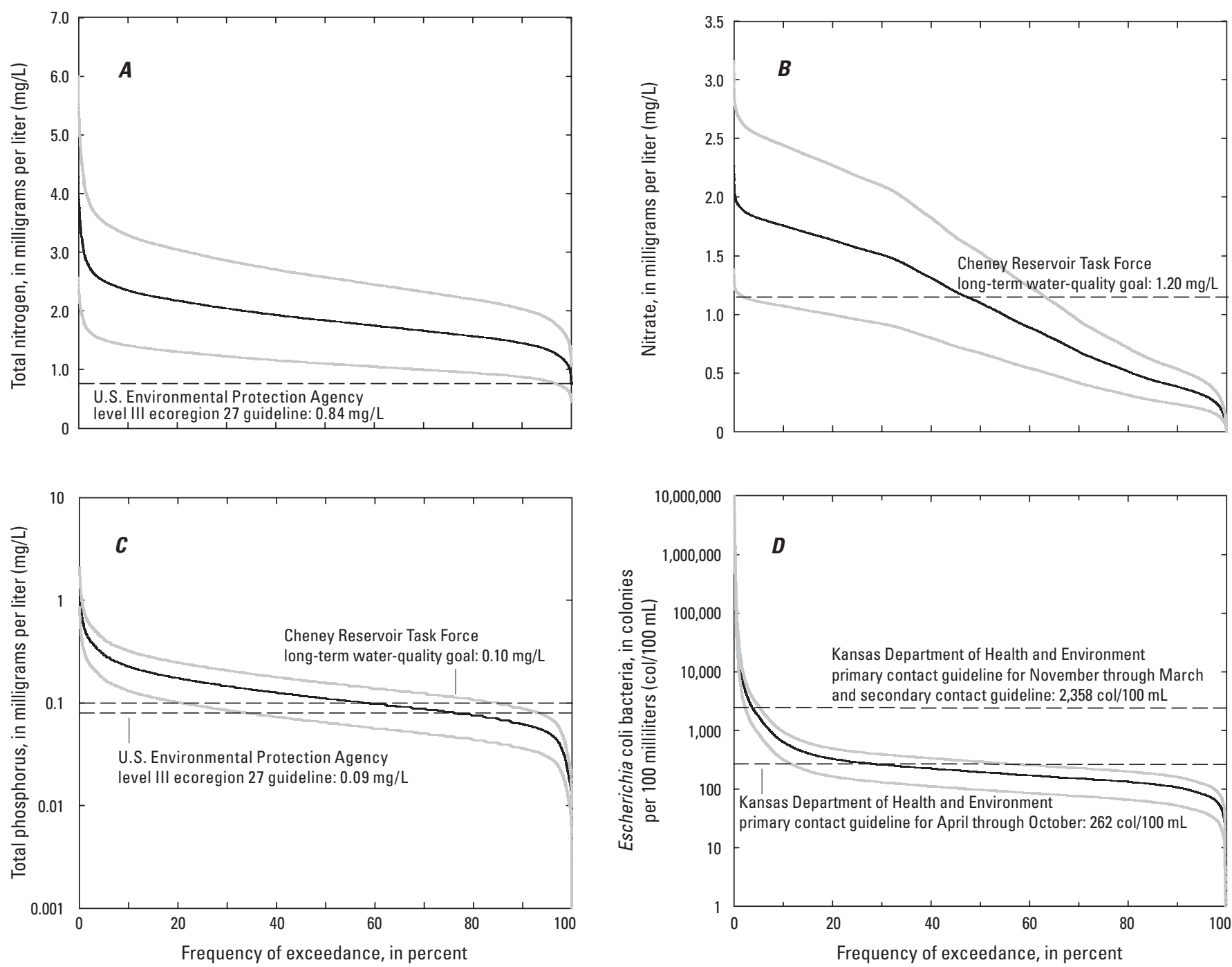

EXPLANATION

90-percent prediction interval

Figure 7. Duration curves for hourly computed $A$, total nitrogen; $B$, nitrate; $C$, total phosphorus; and $D$, Escherichia coli bacteria at the North Fork Ninnescah River upstream from Cheney Reservoir (site 07144780), south-central Kansas, during 1999 through 2012.

for primary contact during the rest of the year. The secondary contact criterion for publicly accessible Kansas streams requires that the geometric mean does not exceed 2,358 colony forming units per $100 \mathrm{~mL}$ at any time of the year (Kansas Department of Health and Environment, 2004b). Colony forming units per $100 \mathrm{~mL}$ is equivalent to colonies per $100 \mathrm{~mL}$ (col/100 mL) for this report.

Mean computed E. coli bacteria density, during 1999 through 2012, was $290,000 \mathrm{col} / 100 \mathrm{~mL}$ (range: less than $1 \mathrm{col} / 100 \mathrm{~mL}$ to $1,900,000,000 \mathrm{col} / 100 \mathrm{~mL}$; table 5). The KDHE primary contact guideline for April to October ( $262 \mathrm{col} / 100 \mathrm{~mL}$ ) was exceeded about 30 percent of the time and the KDHE primary contact guideline for the months between November and March and secondary contact guideline $(2,358 \mathrm{col} / 100 \mathrm{~mL})$ was exceeded about 4 percent of the time (fig. 7D). Year-round data were used to quantify exceedances and geometric means were not calculated; therefore, exceedances of specified values do not indicate non-compliance with these water-quality standards, but do provide an indication of general conditions relative to the criteria.

\section{Comparison of Total Suspended Solids, Nitrate, and Total Phosphorus with Cheney Reservoir Task Force Goals}

Streamflow, total suspended solids, nitrate, and total phosphorus data were separated into three flow class conditions: long term, which includes all streamflow conditions; base flow; and runoff for comparison with Cheney Reservoir 
Task Force goals (table 1). Although the USEPA does not have an established water-quality criterion for total suspended solids, the Cheney Reservoir Task Force developed a long-term mean water-quality goal of $100 \mathrm{mg} / \mathrm{L}$ for the North Fork Ninnescah River (table 1; Cheney Reservoir Task Force, 1994). Additionally, the Cheney Reservoir Task Force developed a total suspended solids goal of $20 \mathrm{mg} / \mathrm{L}$ for base flow conditions and $550 \mathrm{mg} / \mathrm{L}$ for runoff conditions (table 1; Cheney Reservoir Task Force, 1994). Total suspended solids concentrations ranged from less than $1 \mathrm{mg} / \mathrm{L}$ to $1,595 \mathrm{mg} / \mathrm{L}$ during 1999 through 2012 (table 5). The Cheney Reservoir Task Force long-term water-quality goal for total suspended solids $(100 \mathrm{mg} / \mathrm{L})$ was exceeded approximately 10 percent of the time during 1999 through 2012 (fig. 5E, table 8). Mean total suspended solids concentration during base flow conditions was $45 \mathrm{mg} / \mathrm{L}$ and ranged from less than $1 \mathrm{mg} / \mathrm{L}$ to $1,595 \mathrm{mg} / \mathrm{L}$ during 1999 through 2012; the base flow goal for total suspended solids $(20 \mathrm{mg} / \mathrm{L})$ was exceeded about 79 percent of the time (table 8). Mean total suspended solids concentration during runoff conditions was $148 \mathrm{mg} / \mathrm{L}$ and ranged from $6 \mathrm{mg} / \mathrm{L}$ to $1,591 \mathrm{mg} / \mathrm{L}$ during 1999 through 2012; the runoff goal for total suspended solids $(550 \mathrm{mg} / \mathrm{L})$ was exceeded about 3 percent of the time (table 8). When annual mean total suspended solids concentrations were calculated for base flow, runoff, and long-term conditions, the Cheney Reservoir Task Force runoff and long-term goals were never exceeded and the base flow goal of $20 \mathrm{mg} / \mathrm{L}$ was exceeded by $1-4$ fold every year during 1999 through 2012 (fig. 8B).
The Cheney Reservoir Task Force set three goals for nitrate concentrations in Cheney Reservoir watershed streams based on streamflow conditions: $0.25 \mathrm{mg} / \mathrm{L}$ for base flow conditions, $6.60 \mathrm{mg} / \mathrm{L}$ for runoff conditions, and $1.20 \mathrm{mg} / \mathrm{L}$ for long-term conditions (Cheney Reservoir Task Force, 1994; table 1). Nitrate concentrations ranged from less than $0.01 \mathrm{mg} / \mathrm{L}$ to $2.27 \mathrm{mg} / \mathrm{L}$ during 1999 through 2012 (table 5). The Cheney Reservoir Task Force long-term water-quality goal for nitrate $(1.20 \mathrm{mg} / \mathrm{L})$ was exceeded approximately 45 percent of the time (fig. 7B, table 8) during 1999 through 2012. Mean nitrate concentration during base flow conditions was $1.11 \mathrm{mg} / \mathrm{L}$ and ranged from less than $0.01 \mathrm{mg} / \mathrm{L}$ to $2.27 \mathrm{mg} / \mathrm{L}$ during 1999 through 2012; the base flow goal for nitrate $(0.25 \mathrm{mg} / \mathrm{L})$ was exceeded about 99 percent of the time (table 8). Mean nitrate concentration during runoff conditions was $0.85 \mathrm{mg} / \mathrm{L}$ and ranged from less than $0.01 \mathrm{mg} / \mathrm{L}$ to $2.02 \mathrm{mg} / \mathrm{L}$ during 1999 through 2012; the runoff goal for nitrate $(6.60 \mathrm{mg} / \mathrm{L})$ was never exceeded (table 8$)$. When annual mean nitrate concentrations were calculated for base flow, runoff, and long-term conditions, the Cheney Reservoir Task Force runoff goal was never exceeded, the longterm goal was exceeded in 2012, and the base flow goal was exceeded by $4-5$ fold every year during 1999 through 2012 (fig. 8C). With the exception of the years 2000, 2011, and 2012, annual mean nitrate concentrations were larger during base flow conditions than during runoff conditions (fig. 8C). Higher mean nitrate concentrations during base flow conditions, rather than runoff conditions, indicate that groundwater

Table 8. Summary statistics for selected water-quality constituents computed with updated regression models and continuously measured physical properties at the North Fork Ninnescah River upstream from Cheney Reservoir (site 07144780), south-central Kansas, 1999 through 2012.

[Continuous real-time water quality data are available on the U.S. Geological Survey National Real-Time Water-Quality Web site (http://nrtwq.usgs.gov/ks); $n$, number of measurements; $\mathrm{mg} / \mathrm{L}$, milligrams per liter; $<$, less than]

Flow Condition

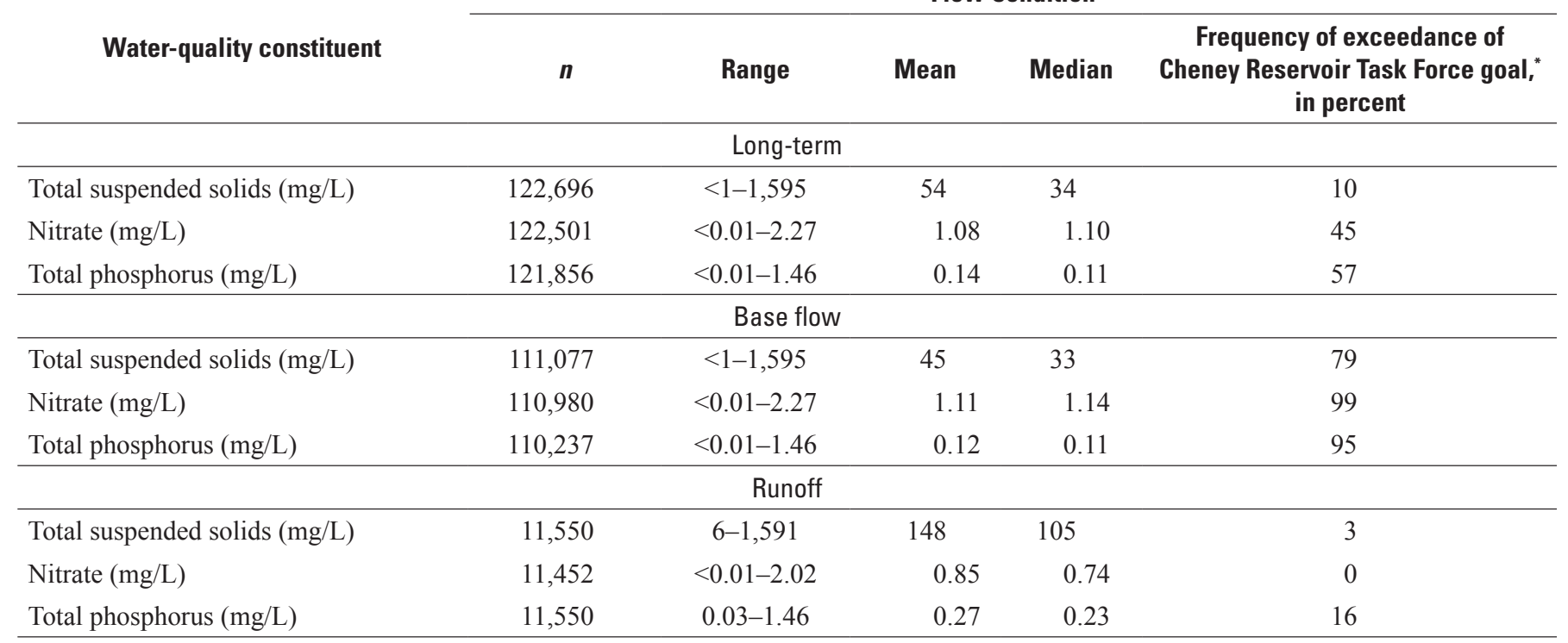

"Cheney Reservoir Task Force, 1994. 


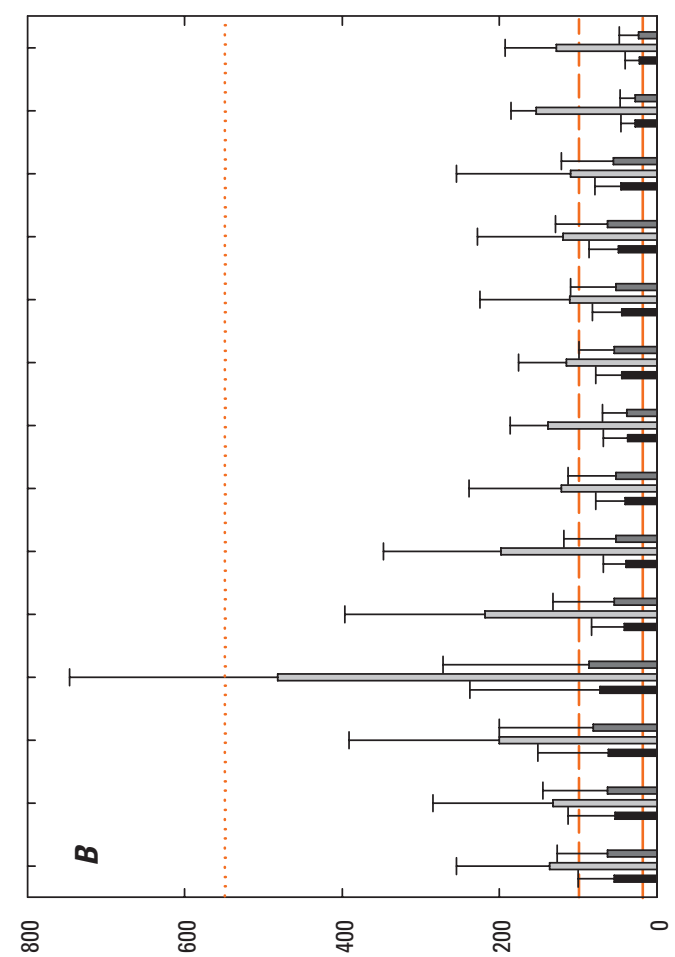

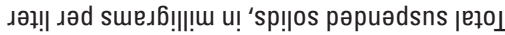

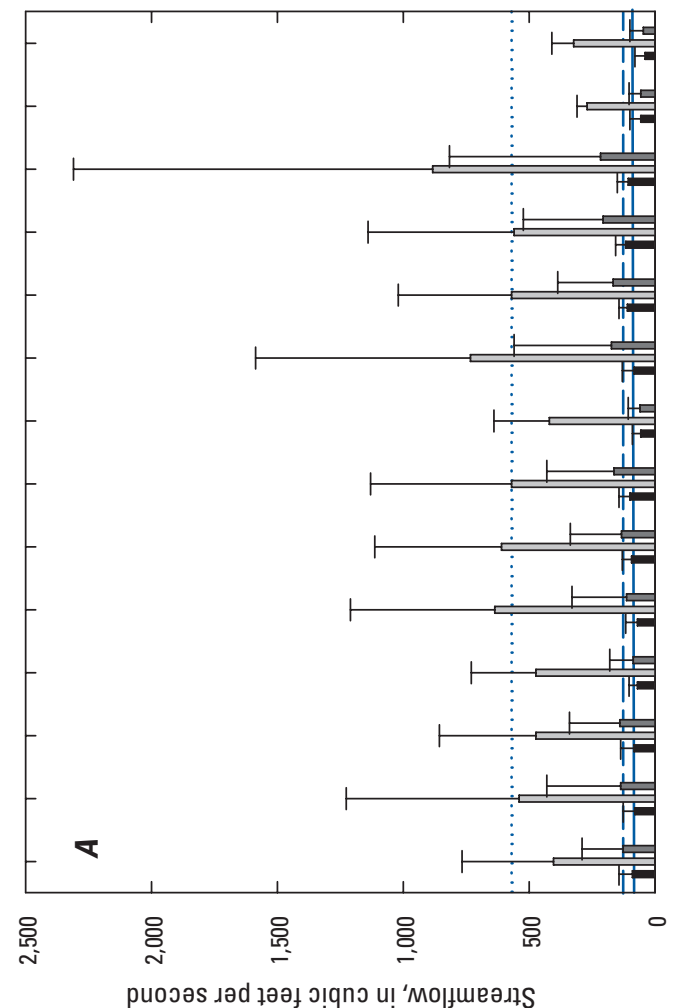

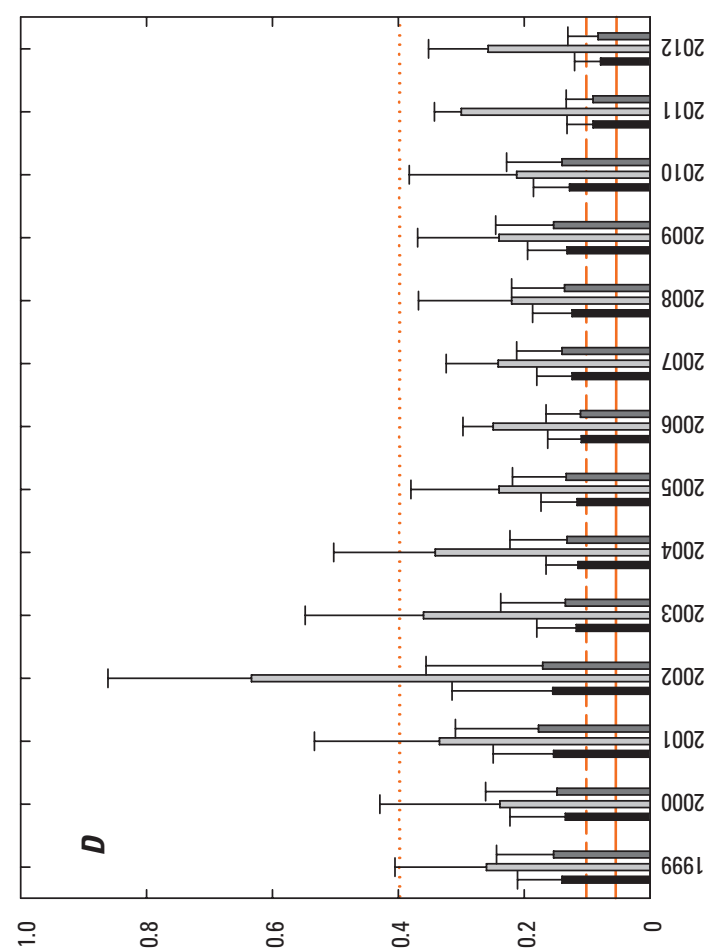

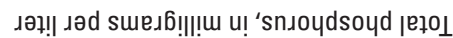

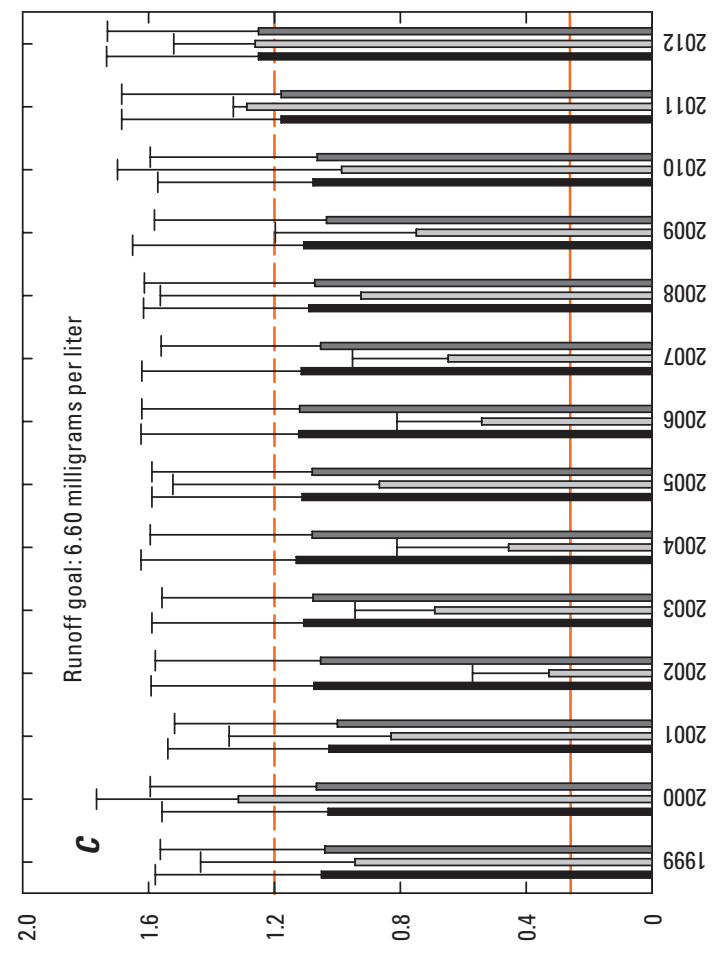

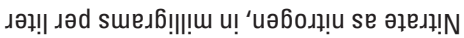

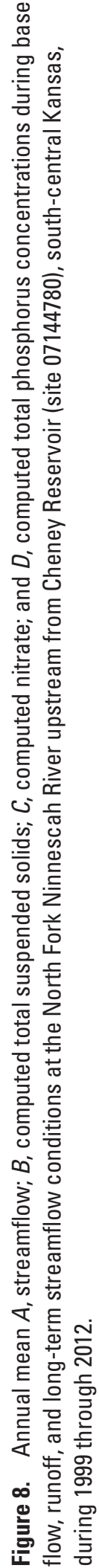


sources are the main contribution of nitrate to the North Fork Ninnescah River.

The Cheney Reservoir Task Force established mean stream water-quality goals for total phosphorus concentrations under three streamflow conditions: $0.05 \mathrm{mg} / \mathrm{L}$ for base flow conditions, $0.40 \mathrm{mg} / \mathrm{L}$ for runoff conditions, and $0.10 \mathrm{mg} / \mathrm{L}$ for long-term conditions (Cheney Reservoir Task Force, 1994; table 1). Total phosphorus concentrations ranged from less than $0.01 \mathrm{mg} / \mathrm{L}$ to $1.46 \mathrm{mg} / \mathrm{L}$ during 1999 through 2012 (table 5). The Cheney Reservoir Task Force long-term water-quality goal for total phosphorus $(0.10 \mathrm{mg} / \mathrm{L})$ was exceeded approximately 57 percent of the time during 1999 through 2012 (fig. $7 C$; table 8). Mean total phosphorus during base flow conditions was $0.12 \mathrm{mg} / \mathrm{L}$ and ranged from less than $0.01 \mathrm{mg} / \mathrm{L}$ to $1.46 \mathrm{mg} / \mathrm{L}$ during 1999 through 2012; the base flow goal for total phosphorus $(0.05 \mathrm{mg} / \mathrm{L})$ was exceeded about 95 percent of the time (table 8). Mean total phosphorus concentration during runoff conditions was $0.27 \mathrm{mg} / \mathrm{L}$ and ranged from $0.03 \mathrm{mg} / \mathrm{L}$ to $1.46 \mathrm{mg} / \mathrm{L}$ during 1999 through 2012 ; the runoff goal for total phosphorus $(0.40 \mathrm{mg} / \mathrm{L})$ was exceeded about 16 percent of the time (table 8 ). When annual mean total phosphorus concentrations were calculated for base flow, runoff, and long-term conditions, the Cheney Reservoir Task Force runoff goal was exceeded in 2002, which was the year with the largest annual mean turbidity (fig. $8 D$; tables 6,8 ); the longterm goal was exceeded every year except 2011 and 2012, which were the years with the smallest mean streamflows (fig. $8 D$; tables 6,8 ). The base flow goal was exceeded every year by 2-3 fold during 1999 through 2012 (fig. $8 D$ ).

Base flow goals for total suspended solids, nitrate, and total phosphorus were exceeded much more frequently (79 to 99 percent of the time) than long-term (10 to 57 percent of the time) or runoff ( 0 to 16 percent of the time) goals. In addition, annual mean concentrations of these constituents during base flow exceeded base flow goals by up to 5 fold. A study by Pope and others (2002) indicated that natural background concentrations of phosphorus in some streams in the Cheney Reservoir watershed would not meet the base flow or longterm goals established by the Cheney Reservoir Task Force. Likewise, the current study indicates that groundwater has a substantial influence on nitrate concentrations in the North Fork Ninnescah River. Given natural background concentrations, groundwater influences, and the exceedance of base flow goals even during extremely dry years, the established base flow goals for total suspended solids, nitrate, and total phosphorus may be unattainable or substantially more BMPs may be needed to obtain them.

On an annual average basis no discernible patterns were evident in total suspended sediment, nitrate, and total phosphorus concentrations or loads over time, in large part because of hydrologic variability. However, more rigorous statistical analyses are required to evaluate temporal trends. A more rigorous analysis of temporal trends will allow evaluation of watershed investments in BMPs.

\section{Summary}

The North Fork Ninnescah River is the largest contributing tributary to Cheney Reservoir in south-central Kansas. Cheney Reservoir is one of the primary sources of water for the city of Wichita. Site-specific regression models were originally published in 2006. Regression equations were updated based on continuous physical property measurements and analyses of discrete water samples collected from 1999 through 2009. The original models for dissolved solids, sodium, chloride, sulfate, calcium, magnesium, potassium, alkalinity, bicarbonate, total suspended solids, suspendedsediment concentration, total Kjeldahl nitrogen, total phosphorus, orthophosphate, and fecal coliform bacteria were updated. New regression models were developed for total nitrogen, nitrate, organic nitrogen, Escherichia coli (E. coli) bacteria, and total organic carbon.

In general, model forms and the amount of variance explained by the models was similar between the original and updated models. The amount of variance explained by the updated models changed by 10 percent or less relative to the original models. Additional data collection over a wider range of hydrological conditions facilitated the development of the new models. The nitrate model is particularly important because it allows for comparison to Cheney Reservoir Task Force goals.

In-stream continuous turbidimeters were changed from Yellow Springs Instruments (YSI) model 6026 (YSI ${ }_{6026}$ ) to YSI model $6136\left(\mathrm{YSI}_{6136}\right)$ sensors in 2011, and a relation between the continuous turbidity values of both sensors was developed. The relation between the different turbidity values measured by the different sensor models was updated and a conversion factor of 0.68 was established to convert the YSI $_{6026}$ turbidity measurements to YSI $_{6136}$ measurements at the North Fork Ninnescah River above Cheney Reservoir site.

Mean North Fork Ninnescah River streamflow during 1999 through 2012 was 129 cubic feet per second $\left(\mathrm{ft}^{3} / \mathrm{s}\right)$ and was smaller than the mean streamflow for the period of record (July 1965 through December 2009; $141 \mathrm{ft}^{3} / \mathrm{s}$ ). Streamflows were smallest in 2012 and largest in 2010. A 10 percent streamflow-separation point occurred at $208 \mathrm{ft}^{3} / \mathrm{s}$ and was used to define base flow and runoff conditions. Continuously measured $\mathrm{pH}$ exceeded the Kansas aquatic-life-support criterion of 8.5 about 19 percent of the time during 1999 through 2012, primarily during base flow conditions in spring and summer, and likely was caused by increased algal photosynthesis. Continuously measured dissolved oxygen concentrations were less than the Kansas aquatic-life-support criterion of $5.0 \mathrm{mg} / \mathrm{L}$ less than 1 percent of the time during 1999 through 2012. Continuously measured turbidity concentrations exceeded the U.S. Environmental Protection Agency's (USEPA) turbidity guideline of 22.13 nephelometric turbidity units about 55 percent of the time during 1999 through 2012; these turbidity exceedances occurred during the range of streamflows.

Hourly concentrations or densities were calculated for selected constituents using the updated and newly developed 
models. Mean and median hourly concentrations or densities were computed for each constituent and the percent of hourly values that exceeded relevant Federal, State, or Cheney Reservoir Task Force water-quality criteria or goals was calculated for 1999 through 2012. Loads for selected constituents also were quantified for 1999 through 2012.

Mean computed hourly sodium concentration during 1999 through 2012 was 168 milligrams per liter (mg/L), likely resulting from the seepage of affected groundwater. Mean computed hourly chloride concentration was $234 \mathrm{mg} / \mathrm{L}$. Mean computed total suspended solids concentration was $54 \mathrm{mg} / \mathrm{L}$. The total suspended solids load was 174,031 tons. Mean suspended sediment was $88 \mathrm{mg} / \mathrm{L}$; annual mean suspended sediment was lowest in 2012 and highest in 2009, corresponding to the smallest and second-largest annual mean streamflows. Suspended-sediment load for was 518,321 tons.

The USEPA recommended total nitrogen guideline of $0.84 \mathrm{mg} / \mathrm{L}$ was exceeded nearly 100 percent of the time. The total nitrogen load was 3,098 tons and was smallest in 2011 and 2012 and largest in 2010, corresponding to the smallest and largest annual mean streamflows and streamflow loads. Mean hourly nitrate was $1.08 \mathrm{mg} / \mathrm{L}$ during the study period. The nitrate load for the study period was 1,361 tons. The mean total phosphorus concentration was $0.14 \mathrm{mg} / \mathrm{L}$. The USEPA level III ecoregion 27 total phosphorus guideline of $0.09 \mathrm{mg} / \mathrm{L}$ was exceeded approximately 67 percent of the time. The total phosphorus load for the study period was 328 tons.

When annual mean total suspended solids concentrations were calculated for base flow, runoff, and long-term conditions, the Cheney Reservoir Task Force runoff and long-term goals usually were never exceeded, but the base flow goal was exceeded every year. The Cheney Reservoir Task Force longterm water-quality goal for nitrate of $1.20 \mathrm{mg} / \mathrm{L}$ was exceeded about 45 percent of the time. When annual mean nitrate concentrations were calculated for base flow, runoff, and long-term conditions, the Cheney Reservoir Task Force runoff $(6.60 \mathrm{mg} / \mathrm{L})$ goal was never exceeded, the long-term goal was exceeded in 2012, and the base flow goal of $0.25 \mathrm{mg} / \mathrm{L}$ was exceeded every year. Mean nitrate concentrations that were higher during base flow, rather than runoff, conditions suggest that groundwater sources are the main contributors of nitrate to the North Fork Ninnescah River above Cheney Reservoir.

The Cheney Reservoir Task Force long-term phosphorus goal of $0.10 \mathrm{mg} / \mathrm{L}$ was exceeded about 57 percent of the time. The Cheney Reservoir Task Force runoff goal for total phosphorus of $0.40 \mathrm{mg} / \mathrm{L}$ was exceeded in 2002, the year with the largest yearly mean turbidity, and the long-term goal was exceeded in every year except 2011 and 2012, the years with the smallest mean streamflows. The total phosphorus base flow goal of $0.05 \mathrm{mg} / \mathrm{L}$ was exceeded every year.

Base flow goals for total suspended solids, nitrate, and total phosphorus were exceeded much more frequently (79 to 99 percent of the time) than long-term (10 to 57 percent of the time) or runoff ( 0 to 16 percent of the time) goals. In addition, annual mean concentrations of these constituents during base flow exceeded base flow goals by up to 5 fold. Given natural background concentrations, groundwater influences, and the exceedance of base flow goals even during extremely dry years, the established base flow goals for total suspended solids, nitrate, and total phosphorus may be unattainable or substantially more best management practices (BMPs) may be needed to attain them.

On an annual average basis no discernible patterns were evident in total suspended sediment, nitrate, and total phosphorus concentrations or loads over time, in large part because of hydrologic variability. However, more rigorous statistical analyses are required to evaluate temporal trends. A more rigorous analysis of temporal trends will allow evaluation of watershed investments in BMPs.

\section{References Cited}

Allan, J.D., 1995, Stream ecology-Structure and function of running waters: Boston, Mass., Kluwer Academic Publishers, $388 \mathrm{p}$.

American Public Health Association, American Water Works Association, and Water Environment Federation, 1995, Standard methods for the examination of water and wastewater (19th ed.): Washington D.C., American Public Health Association, $905 \mathrm{p}$.

Anderson, C.W., 2005, Turbidity, in National field manual for the collection of water-quality data: U.S. Geological Survey Techniques of Water-Resources Investigations, book 9, chap. 6.7, p. 1-59.

ASTM International, 2003, D1889-00 standard test method for turbidity of water, in ASTM International, Annual book of ASTM standards, water and environmental technology: West Conshohocken, Pennsylvania, American Society for Testing and Materials, v. 11.01, 6 p.

Cheney Reservoir Task Force, 1994, Watershed pollution management plan for North Fork Ninnescah Watershed and Cheney Reservoir, Final Report, 22 p.

Childress, C.J.O., Foreman, W.T., Conor, B.F., and Maloney, T.J., 1999, New report procedures based on long-term method detection levels and some considerations for interpretations of water-quality data provided by the U.S. Geological Survey National Water Quality Laboratory: U.S. Geological Survey Open-File Report 99-193, 19 p.

Christensen, V.G., Graham, J.L., Milligan, C.R., Pope, L.M., and Ziegler, A.C., 2006, Water quality and relation to tasteand-odor compounds in the North Fork Ninnescah River and Cheney Reservoir, south-central Kansas, 1997-2003: U.S. Geological Survey Scientific Investigations Report 2006-5095, 43 p. 
Christensen, V.G., and Pope, L.M., 1997, Occurrence of dissolved solids, nutrients, atrazine, and fecal coliform bacteria during low flow in the Cheney Reservoir watershed, south-central Kansas, 1996: U.S. Geological Survey WaterResources Investigations Report 97-4153, 13 p.

Chorus, I., and Bartram, J., eds., 1999, Toxic cyanobacteria in water-A guide to their public health consequences, monitoring and management: London, E \& FN Spon, 416 p.

Duan, N., 1983, Smearing estimate a nonparametric retransformation method: Journal of the American Statistical Association, v. 78, no. 383, p. 605-610.

Fishman, M.J., and Friedman, L.C., 1989, Methods for determination of inorganic substances in water and fluvial sediments: U.S. Geological Survey Techniques of WaterResources Investigations, book 5, chap. A1, 545 p.

Gillespie, J.B., and Hargadine, G.D., 1994, Geohydrology and saline ground-water discharge to the South Fork Ninnescah River in Pratt and Kingman Counties, south-central Kansas: U.S. Geological Survey Water-Resources Investigations Report 93-4177, $51 \mathrm{p}$.

Graham, J.L., Loftin, K.A., Ziegler, A.C., and Meyer, M.T., 2008, Guidelines for design and sampling for cyanobacterial toxin and taste-and-odor studies in lakes and reservoirs: U.S. Geological Survey Scientific Investigations Report 2008-5038, 39 p.

Graham, J.L., Stone, M.L., Rasmussen, T.J., and Poulton, B.C., 2010, Effects of wastewater effluent discharge and treatment facility upgrades on environmental and biological conditions of the upper Blue River, Johnson County, Kansas and Jackson County, Missouri, January 2003 through March 2009: U.S. Geological Survey Scientific Investigations Report 2010-5248, 85 p.

Guy, H.P., 1969, Laboratory theory and methods for sediment analysis: U.S. Geological Survey Techniques of WaterResources Investigations, book 5, chap. C1, 58 p.

Hardison, C.H., 1969, Accuracy of streamflow characteristics, in Geological Survey Research, 1969: U.S. Geological Survey Professional Paper 650-D, p. D210-D214.

Helsel, D.R., and Hirsch, R.M., 2002, Statistical methods in water resources-hydrologic analysis and interpretation: U.S. Geological Survey Techniques of Water-Resources Investigations, book 4, chap. A3, $510 \mathrm{p}$.

Hem, J.D., 1992, Study and interpretation of chemical characteristics of natural water (3d ed.): U.S. Geological Survey Water-Supply Paper 2254, 263 p.

Judge, G.G., Griffiths, W.E., Hill, R.C., Lutkepohl, H., and Lee, T.C., 1985, Qualitative and limited dependent variable models, chap. 18 of The theory and practice of econometrics: New York, John Wiley and Sons.
Kansas Applied Remote Sensing Program, 2009, Kansas Land Cover Patterns, accessed August 2012, at http://www.kars. ku.edu/research/2005-kansas-land-cover-patterns-level-iv/.

Kansas Department of Health and Environment, 2001, Lower Arkansas River basin total maximum daily load, accessed March 2011 at http://www.kdheks.gov/tmdl/la/NFNinnescah. $p d f$.

Kansas Department of Health and Environment, 2004a, Surface water nutrient reduction plan: Topeka, Kansas, Bureau of Water, 47 p., accessed June 2011, at http://water.epa.gov/ scitech/swguidance/standards/criteria/nutrients/upload/ Kansas-SURFACE-WATER-NUTRIENT-REDUCTIONPLAN-DECEMBER-29-2004.pdf.

Kansas Department of Health and Environment, 2004b, Kansas surface water quality standards-Tables of numeric criteria, accessed March 2011, at http://www.kdheks.gov/ water/download/tables_of_numeric_criteria.pdf.

Kansas Department of Health and Environment, 2008, Kansas Administrative Regulations (KAR), Title 28, Article 16, Surface water quality standards 2008: Topeka, Kansas, Secretary of State [variously paged].

Kansas Department of Health and Environment, 2010, Kansas surface water register, accessed November 2012 at http:// www.kdheks.gov/befs/download/Current_Kansas_Surface_ Register.pdf.

Kansas Department of Health and Environment, 2012, 2012 303(d) list of impaired waters, accessed November 2012 at http://www.kdheks.gov/tmdl/2012/303d_List_Long.pdf.

Kansas Department of Health and Environment, [n.d.], Kansas TMDL curve methodology: Bureau of Water, Watershed, Planning, Monitoring, and Assessment Section, accessed May 2012, at http://www.kdheks.gov/tmdl/basic.htm.

Lewis, M.E., 2006, Dissolved oxygen: U.S. Geological Survey Techniques of Water Resources Investigations, book 9, chap. A6, section 6.2, accessed February 2011, at http:// pubs.water.usgs.gov/twri9A6.

Maidment, D.R., 1993, Handbook of hydrology: New York, McGraw-Hill, Inc., [variously paged].

Mau, D.P., 2001, Sediment depositional trends and transport of phosphorus and other chemical constituents, Cheney Reservoir watershed, south-central Kansas: U.S. Geological Survey Water-Resources Investigations Report 01-4085, $40 \mathrm{p}$.

National Climatic Data Center, 2012, Monthly surface data (3220), accessed January 2012, at http://www.ncdc.noaa. gov/oa/ncdc.html. 
National Research Council (U.S.), 2004, Indicators for waterborne pathogens: Committee on Indicators for Waterborne Pathogens, Washington D.C., National Academies Press, $332 \mathrm{p}$.

Peterson, D.L., Whistler, J.L., Lomas, J.M., Dobbs, K.E., Jakubauskas, M.E., and Martinko, E.A., 2005, 2005 Kansas land cover patterns phase I: University of Kansas, Kansas Biological Survey, Report 150, 29 p.

Pope, L.M., 1998, Watershed trend analysis and water-quality assessment using bottom-sediment cores from Cheney Reservoir, south-central Kansas: U.S. Geological Survey Water-Resources Investigations Report 98-4227, 24 p.

Pope, L.M., and Christensen, V.G., 1997, Water-quality study of the Cheney Reservoir watershed, south-central Kansas: U.S. Geological Survey Fact Sheet 104-97, 2 p.

Pope, L.M., and Milligan, C.R., 2000, Preliminary assessment of phosphorus transport in the Cheney Reservoir watershed, south-central Kansas, 1997-98: U.S. Geological Survey Water-Resources Investigations Report 00-4023, 29 p.

Pope, L.M., Milligan, C.R., and Mau, D.P., 2002, Historical contributions of phosphorus from natural and agricultural sources and implications for stream water quality, Cheney Reservoir watershed, south-central Kansas: U.S. Geological Survey Water-Resources Investigations Report 02-4021, $25 \mathrm{p}$.

Porterfield, G., 1972, Computation of fluvial-sediment discharge: U.S. Geological Survey Techniques of WaterResources Investigations, book 3, chap C3, 66 p.

Rasmussen, P.P., and Ziegler, A.C., 2003, Comparison and continuous estimates of fecal coliform and Escherichia coli bacteria in selected Kansas streams, May 1999 through April 2002: U.S. Geological Survey Water-Resources Investigations Report 03-4056, $80 \mathrm{p}$.

Rasmussen, P. P., Gray, J.R., Glysson, G.D., and Ziegler, A.C., 2009, Guidelines and procedures for computing time-series suspended-sediment concentrations and loads from instream turbidity sensor and streamflow data: U.S. Geological Survey Techniques and Methods book 3, chap. C4, 53 p.

Rasmussen, T.J., Zeigler, A.C, and Rasmussen, P.P., 2005, Estimation of constituent concentrations, densities, loads, and yields in lower Kansas River, northeast Kansas, using regression models and continuous water-quality monitoring, January 2000 through December 2003: U.S. Geological Survey Scientific Investigations Report 2005-5165, 117 p.
Rasmussen, T.J., Lee, C.J., and Ziegler, A.C., 2008, Estimation of constituent concentrations, loads, and yields in streams of Johnson County, northeast Kansas, using continuous waterquality monitoring and regression models, October 2002 through December 2006: U.S. Geological Survey Scientific Investigations Report 2008-5014, 103 p.

Sauer, V.B., and Turnipseed, D.P., 2010, Stage measurement at gaging stations: U.S. Geological Survey Techniques and Methods, book 3, chap. A7, 45 p.

Simley, J.D., Carswell W.J., Jr., 2009, The National MapHydrography: U.S. Geological Survey Fact Sheet 20093054, 4 p.

Smith, V.H., deNoyelles, F., Jr., Graham, D.W., and Randtke, S.J., 2001, A comparative water quality study of Cheney Reservoir, Kansas - final report to the city of Wichita Water and Sewer Department: Lawrence, University of Kansas, Department of Ecology and Evolutionary Biology, 28 p.

Sokal, R.R., and Rohlf, F.J., 1995, Biometry-the principles and practice of statistics in biological research ( $3 \mathrm{~d}$ ed.): New York, W.H. Freeman and Company, 887 p.

Stone, M.L., Graham, J.L., and Gatotho, J.W., 2013, Model documentation for relations between continuous real-time and discrete water-quality constituents in the North Fork Ninnescah River upstream from Cheney Reservoir, southcentral Kansas, 1999-2009: U.S. Geological Survey OpenFile Report 2013-1014, 101 p.

Stone, M.L., Graham, J.L., and Ziegler, A.C., 2009, Twelve years of monitoring phosphorus and suspended-solids concentrations and yields in the North Fork Ninnescah River above Cheney Reservoir, south-central Kansas 1997-2008: U.S. Geological Survey Fact Sheet 2009-3073, 4 p.

Taylor, W.D., Losee, R.F., Torobin, M., Izaguirre, G., Sass, D., Khiari, D., and Atasi, K., 2005, Early warning and management of surface water taste-and-odor events: AWWA Research Foundation, $373 \mathrm{p}$.

TIBCO Software, Inc., 2008, TIBCO Spotfire $S+{ }^{\circledR} 8.1$ for Windows ${ }^{\circledR}$ User’s Guide, 582 p.

Turnipseed, D.P., and Sauer, V.B., 2010, Discharge measurements at gaging stations: U.S. Geological Survey Techniques and Methods, book 3, chap. A8, 87 p.

U.S. Department of Agriculture, 2012, Watershed Boundary Dataset for Kansas, accessed December 2011, at http:// datagateway.nrcs.usda.gov/. 
U.S. Environmental Protection Agency, 2000, Nutrient criteria technical guidance manual-Rivers and streams: U.S. Environmental Protection Agency Report 822-B-00-002, [variously paged].

U.S. Environmental Protection Agency, 2002, Summary table for the nutrient criteria documents, accessed March 2011, at http://water.epa.gov/scitech/swguidance/standards/ criteria/nutrients/upload/2007_09_27_criteria_nutrient_ ecoregions_sumtable.pdf.

U.S. Environmental Protection Agency, 2005, Current drinking-water standards, accessed March 2011, at http://www. epa.gov/safewater/mcl.html.

U.S. Environmental Protection Agency, 2006, Wadeable streams assessment: a collaborative survey of the nation's streams: U.S. Environmental Protection Agency Report 841-B-06-002, [variously paged].

U.S. Environmental Protection Agency, 2009, 2009 Edition of the drinking water standards and health advisories: Office of Water, EPA 822-R-09-011, 18 p.

U.S. Geological Survey, 2006, Collection of water samples (ver. 2.0): U.S. Geological Survey Techniques of WaterResources Investigations, book 9, chap. A4, accessed March 2011, at http://pubs.water.usgs.gov/twri9A4/.

Wagner, R.J., Boulger, R.W., Jr., Oblinger, C.J., and Smith, B.A., 2006, Guidelines and standard procedures for continuous water-quality monitors - station operation, record computation, and data reporting: U.S. Geological Survey Techniques and Methods, book 1, chap D3, $51 \mathrm{p}$.
Walton, G., 1951, Survey of literature relating to infant methemoglobinemia due to nitrate-contaminated water: American Journal of Public Health and the Nations Health, v. 41, p. 986-996.

Waters, T.F., 1995, Sediment in streams - sources, biological effects, and control: Bethesda, Maryland, American Fisheries Society Monograph 7, American Fisheries Society.

Wehr, J.D., and Sheath, R.G., eds., 2003, Freshwater algae of North America - ecology and classification: New York, Academic Press, 918 p.

Wetzel, R.G., 2001, Limnology of lake and river ecosystems: New York, Academic Press, 1,006 p.

Wilde, F.D., and Radke, D.B., eds., 1998, Field measurements, in National field manual for the collection of water-quality data: U.S. Geological Survey Techniques of WaterResources Investigations, book 9, chap. A6, p. 3-20.

Ziegler, A.C., and Combs, L.J., 1997, Baseline data-collection and quality control protocols and procedures for the Equus Beds Groundwater Recharge Demonstration Project near Wichita, Kansas, 1995-96: U.S. Geological Survey OpenFile Report 97-235, 57 p.

Ziegler, A.C., Hansen, C.V., and Finn, D.A., 2010, Water quality in the Equus Beds aquifer and the Little Arkansas River before implementation of large-scale artificial recharge, south-central Kansas, 1995-2005: U.S. Geological Survey Scientific Investigations Report 2010-5023, 143 p. 
Appendixes 1-6 
Appendix 1. Sample collection dates and streamflow conditions for discrete water-quality samples included in regression model development for the North Fork Ninnescah River upstream from Cheney Reservoir (site 07144780), south-central Kansas, 1999 through 2009.

[ $\mathrm{ft}^{3} / \mathrm{s}$, cubic feet per second; TDS, total dissolved solids; $\mathrm{Na}$, sodium; $\mathrm{Cl}$, chloride; $\mathrm{SO}_{4}$, sulfate; TSS, total suspended solids; $\mathrm{SSC}$, suspended-sediment concentration; TN, total nitrogen; TKN, nitrogen, ammonia plus organic; $\mathrm{NO}_{3}$, nitrate; TP, total phosphorus; OP, orthophosphate; EC, Escherichia coli bacteria; Ca, calcium; Mg, magnesium; K, potassium; ALK, alkalinity; $\mathrm{HCO}_{3}$, bicarbonate; $\mathrm{ON}$, organic nitrogen; $\mathrm{FC}$, fecal coliform bacteria; TOC, total organic carbon]

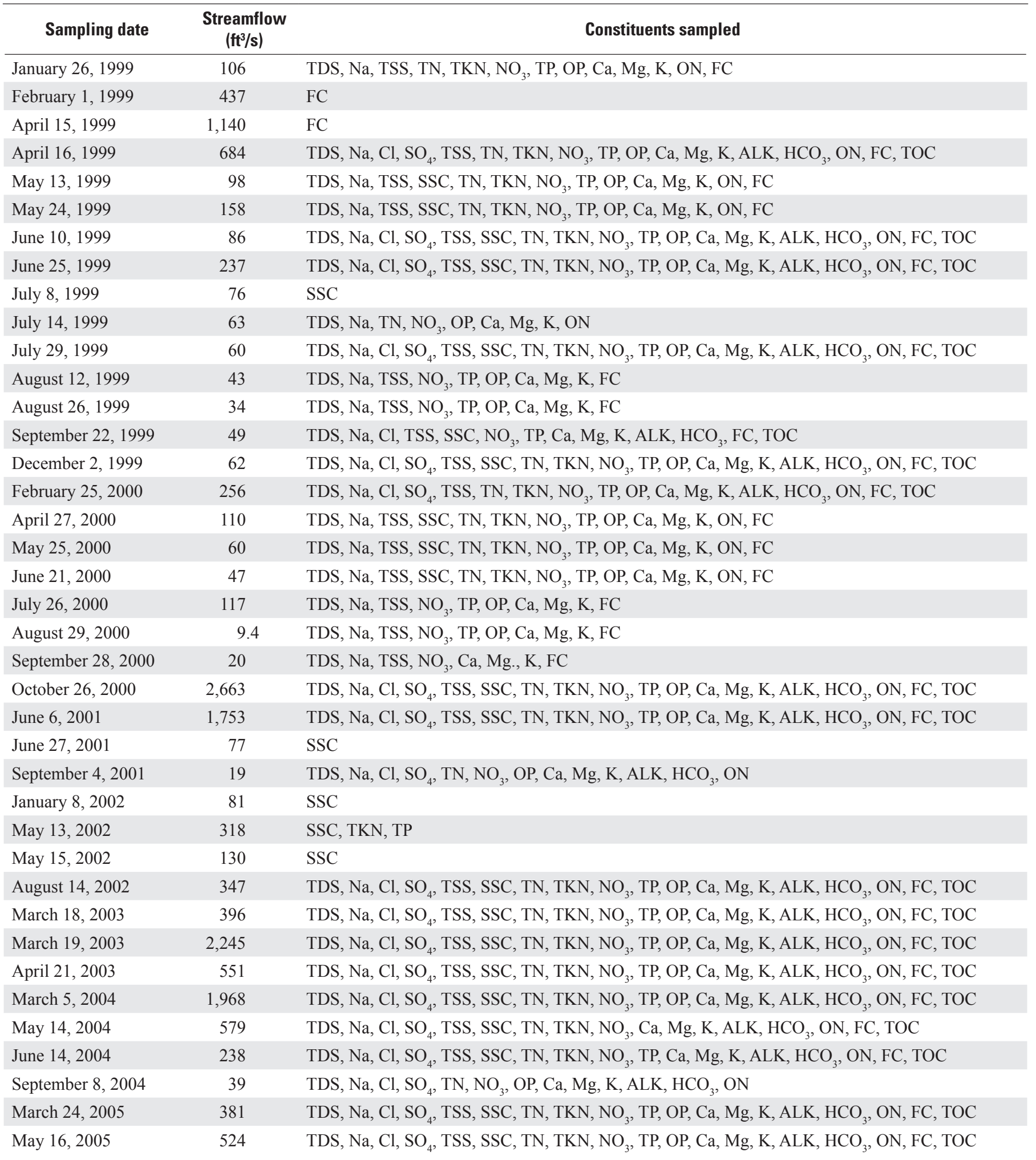


Appendix 1. Sample collection dates and streamflow conditions for discrete water-quality samples included in regression model development for the North Fork Ninnescah River upstream from Cheney Reservoir (site 07144780), south-central Kansas, 1999 through 2009.-Continued

$\left[\mathrm{ft}^{3} / \mathrm{s}\right.$, cubic feet per second; TDS, total dissolved solids; $\mathrm{Na}$, sodium; $\mathrm{Cl}$, chloride; $\mathrm{SO}_{4}$, sulfate; TSS, total suspended solids; $\mathrm{SSC}$, suspended-sediment concentration; TN, total nitrogen; TKN, nitrogen, ammonia plus organic; $\mathrm{NO}_{3}$, nitrate; TP, total phosphorus; OP, orthophosphate; EC, Escherichia coli bacteria; Ca, calcium; $\mathrm{Mg}$, magnesium; $\mathrm{K}$, potassium; $\mathrm{ALK}$, alkalinity; $\mathrm{HCO}_{3}$, bicarbonate; $\mathrm{ON}$, organic nitrogen; $\mathrm{FC}$, fecal coliform bacteria; TOC, total organic carbon]

\begin{tabular}{|c|c|c|}
\hline Sampling date & $\begin{array}{c}\text { Streamflow } \\
\left(\mathrm{ft}^{3} / \mathrm{s}\right)\end{array}$ & Constituents sampled \\
\hline June 10,2005 & 1,100 & TDS, Na, Cl, $\mathrm{SO}_{4}, \mathrm{TSS}, \mathrm{SSC}, \mathrm{TN}, \mathrm{TKN}, \mathrm{NO}, \mathrm{Ca}, \mathrm{Mg}, \mathrm{K}, \mathrm{ALK}, \mathrm{HCO}_{3}, \mathrm{ON}, \mathrm{FC}, \mathrm{TOC}$ \\
\hline June 13,2005 & 3,150 & TDS, Na, Cl, $\mathrm{SO}_{4}, \mathrm{TSS}, \mathrm{SSC}, \mathrm{TN}, \mathrm{TKN}, \mathrm{NO}_{3}, \mathrm{TP}, \mathrm{Ca}, \mathrm{Mg}, \mathrm{K}, \mathrm{ALK}, \mathrm{HCO}_{3}, \mathrm{ON}, \mathrm{FC}, \mathrm{TOC}$ \\
\hline August 29, 2005 & 256 & TDS, Na, Cl, $\mathrm{SO}_{4}, \mathrm{TSS}, \mathrm{SSC}, \mathrm{TN}, \mathrm{TKN}, \mathrm{NO}_{3}, \mathrm{TP}, \mathrm{OP}, \mathrm{Ca}, \mathrm{Mg}, \mathrm{K}, \mathrm{ALK}, \mathrm{HCO}_{3}, \mathrm{ON}, \mathrm{FC}, \mathrm{TOC}$ \\
\hline March 2, 2006 & 92 & TDS, Na, Cl, $\mathrm{SO}_{4}, \mathrm{TSS}, \mathrm{SSC}, \mathrm{NO}_{3}, \mathrm{TP}, \mathrm{OP}, \mathrm{Ca}, \mathrm{Mg}, \mathrm{K}, \mathrm{ALK}, \mathrm{HCO}_{3}, \mathrm{ON}, \mathrm{FC}, \mathrm{TOC}$ \\
\hline May 12, 2006 & 156 & TDS, $\mathrm{Na}, \mathrm{Cl}, \mathrm{SO}_{4}, \mathrm{TN}, \mathrm{NO}_{3}, \mathrm{Ca}, \mathrm{Mg}, \mathrm{K}, \mathrm{ALK}, \mathrm{HCO}_{3}, \mathrm{ON}$ \\
\hline June 5, 2006 & 39 & TDS, Na, Cl, $\mathrm{SO}_{4}, \mathrm{TSS}, \mathrm{SSC}, \mathrm{TN}, \mathrm{TKN}, \mathrm{NO}_{3}, \mathrm{TP}, \mathrm{OP}, \mathrm{Ca}, \mathrm{Mg}, \mathrm{K}, \mathrm{ALK}, \mathrm{HCO}_{3}, \mathrm{ON}, \mathrm{FC}, \mathrm{TOC}$ \\
\hline July 31,2006 & 15 & TDS, Na, Cl, $\mathrm{SO}_{4}, \mathrm{TSS}, \mathrm{SSC}, \mathrm{TN}, \mathrm{TKN}, \mathrm{NO}_{3}, \mathrm{TP}, \mathrm{OP}, \mathrm{EC}, \mathrm{Ca}, \mathrm{Mg}, \mathrm{K}, \mathrm{ALK}, \mathrm{HCO}_{3}, \mathrm{ON}, \mathrm{FC}, \mathrm{TOC}$ \\
\hline September 7, 2006 & 39 & TDS, Na, Cl, $\mathrm{SO}_{4}, \mathrm{TSS}, \mathrm{SSC}, \mathrm{TN}, \mathrm{TKN}, \mathrm{NO}_{3}, \mathrm{TP}, \mathrm{OP}, \mathrm{EC}, \mathrm{Ca}, \mathrm{Mg}, \mathrm{K}, \mathrm{ALK}, \mathrm{HCO}_{3}, \mathrm{ON}, \mathrm{FC}, \mathrm{TOC}$ \\
\hline March 22, 2007 & 98 & TDS, Na, Cl, $\mathrm{SO}_{4}, \mathrm{TSS}, \mathrm{SSC}, \mathrm{TN}, \mathrm{TKN}, \mathrm{NO}_{3}, \mathrm{TP}, \mathrm{OP}, \mathrm{Ca}, \mathrm{Mg}, \mathrm{K}, \mathrm{ALK}, \mathrm{HCO}_{3}, \mathrm{ON}, \mathrm{FC}, \mathrm{TOC}$ \\
\hline March 26, 2007 & 295 & TDS, Na, Cl, $\mathrm{SO}_{4}, \mathrm{TSS}, \mathrm{SSC}, \mathrm{TN}, \mathrm{TKN}, \mathrm{NO}_{3}, \mathrm{TP}, \mathrm{OP}, \mathrm{EC}, \mathrm{Ca}, \mathrm{Mg}, \mathrm{K}, \mathrm{ALK}, \mathrm{HCO}_{3}, \mathrm{ON}, \mathrm{FC}, \mathrm{TOC}$ \\
\hline March 31, 2007 & 1,370 & TDS, Na, Cl, $\mathrm{SO}_{4}, \mathrm{TSS}, \mathrm{SSC}, \mathrm{TN}, \mathrm{TKN}, \mathrm{NO}_{3}, \mathrm{TP}, \mathrm{OP}, \mathrm{Ca}, \mathrm{Mg}, \mathrm{K}, \mathrm{ALK}, \mathrm{HCO}_{3}, \mathrm{ON}, \mathrm{FC}, \mathrm{TOC}$ \\
\hline April 1, 2007 & 1,660 & $\mathrm{EC}, \mathrm{FC}$ \\
\hline April 16, 2007 & 751 & TDS, Na, Cl, $\mathrm{SO}_{4}, \mathrm{TSS}, \mathrm{SSC}, \mathrm{TN}, \mathrm{TKN}, \mathrm{NO}_{3}, \mathrm{TP}, \mathrm{OP}, \mathrm{Ca}, \mathrm{Mg}, \mathrm{K}, \mathrm{ALK}, \mathrm{HCO}_{3}, \mathrm{ON}, \mathrm{FC}, \mathrm{TOC}$ \\
\hline May 7, 2007 & 3,725 & TDS, Na, Cl, $\mathrm{SO}_{4}$, TSS, SSC, TN, TKN, $\mathrm{NO}_{3}, \mathrm{TP}, \mathrm{OP}, \mathrm{Ca}, \mathrm{Mg}, \mathrm{K}, \mathrm{ALK}, \mathrm{HCO}_{3}, \mathrm{ON}, \mathrm{FC}, \mathrm{TOC}$ \\
\hline May 24, 2007 & 4,780 & FC \\
\hline June 29, 2007 & 401 & TDS, Na, Cl, $\mathrm{SO}_{4}, \mathrm{TSS}, \mathrm{SSC}, \mathrm{TN}, \mathrm{TKN}, \mathrm{NO}_{3}, \mathrm{TP}, \mathrm{OP}, \mathrm{Ca}, \mathrm{Mg}, \mathrm{K}, \mathrm{ALK}, \mathrm{HCO}_{3}, \mathrm{ON}, \mathrm{FC}, \mathrm{TOC}$ \\
\hline September 4, 2007 & 28 & TDS, Na, Cl, $\mathrm{SO}_{4}, \mathrm{TSS}, \mathrm{NO}_{3}, \mathrm{TP}, \mathrm{Ca}, \mathrm{Mg}, \mathrm{K}, \mathrm{ALK}, \mathrm{HCO}_{3}, \mathrm{FC}, \mathrm{TOC}$ \\
\hline April 27, 2009 & 2,150 & TDS, Na, Cl, $\mathrm{SO}_{4}, \mathrm{TSS}, \mathrm{SSC}, \mathrm{TN}, \mathrm{TKN}, \mathrm{NO}_{3}, \mathrm{TP}, \mathrm{OP}, \mathrm{Ca}, \mathrm{Mg}, \mathrm{K}, \mathrm{ALK}, \mathrm{HCO}_{3}, \mathrm{ON}, \mathrm{FC}, \mathrm{TOC}$ \\
\hline June 17, 2009 & 349 & TDS, Na, Cl, $\mathrm{SO}_{4}, \mathrm{TSS}, \mathrm{SSC}, \mathrm{TN}, \mathrm{TKN}, \mathrm{NO}_{3}, \mathrm{TP}, \mathrm{OP}, \mathrm{Ca}, \mathrm{Mg}, \mathrm{K}, \mathrm{ALK}, \mathrm{HCO}_{3}, \mathrm{ON}, \mathrm{FC}, \mathrm{TOC}$ \\
\hline August 20, 2009 & 103 & TDS, Na, Cl, $\mathrm{SO}_{4}, \mathrm{TSS}, \mathrm{SSC}, \mathrm{TN}, \mathrm{TKN}, \mathrm{NO}_{3}, \mathrm{TP}, \mathrm{OP}, \mathrm{Ca}, \mathrm{Mg}, \mathrm{K}, \mathrm{ALK}, \mathrm{HCO}_{3}, \mathrm{ON}, \mathrm{FC}, \mathrm{TOC}$ \\
\hline September 10, 2009 & 482 & TDS, Na, Cl, $\mathrm{SO}_{4}, \mathrm{TSS}, \mathrm{SSC}, \mathrm{TN}, \mathrm{TKN}, \mathrm{NO}_{3}, \mathrm{TP}, \mathrm{OP}, \mathrm{Ca}, \mathrm{Mg}, \mathrm{K}, \mathrm{ALK}, \mathrm{HCO}_{3}, \mathrm{ON}, \mathrm{FC}, \mathrm{TOC}$ \\
\hline
\end{tabular}




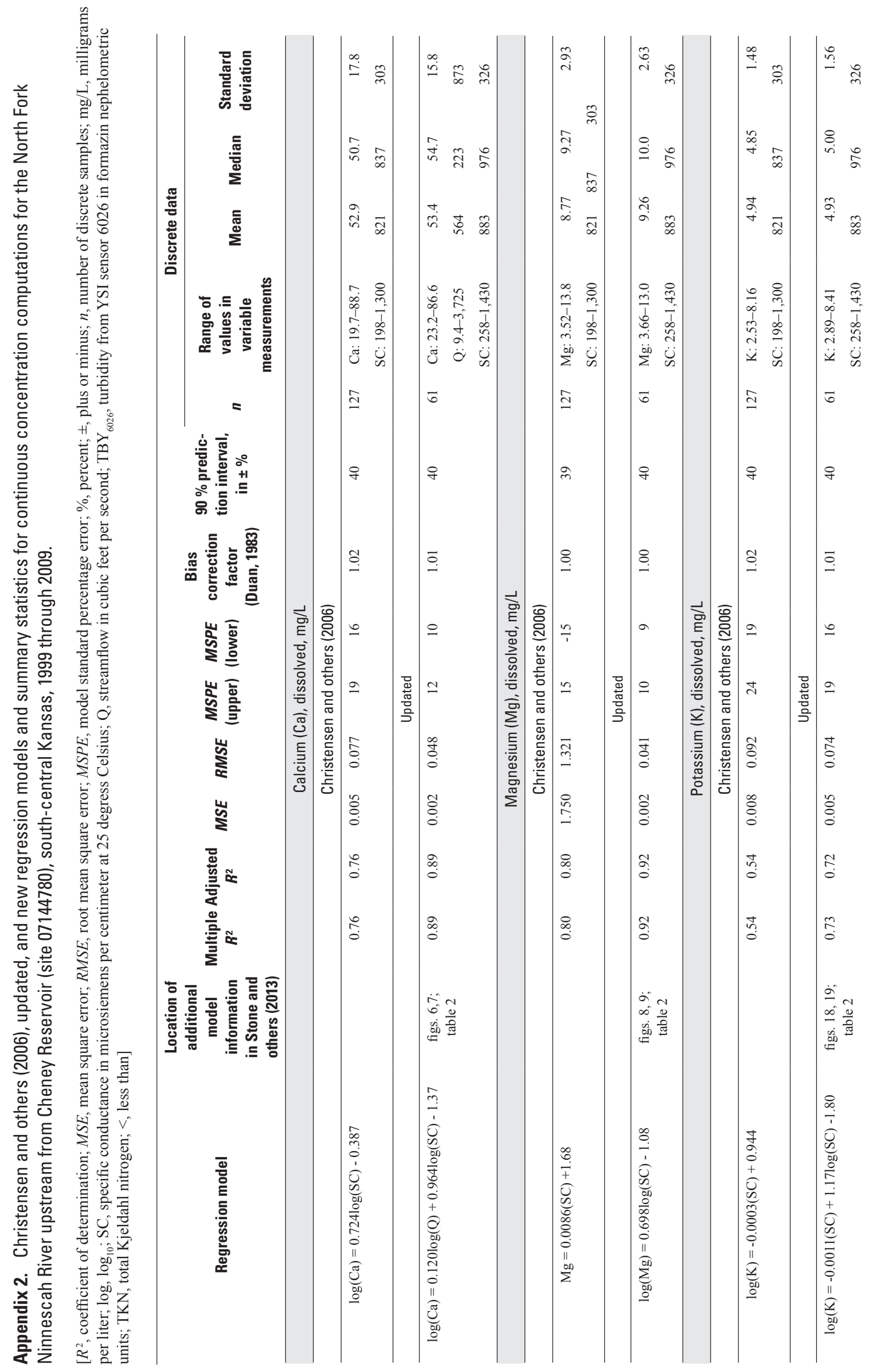




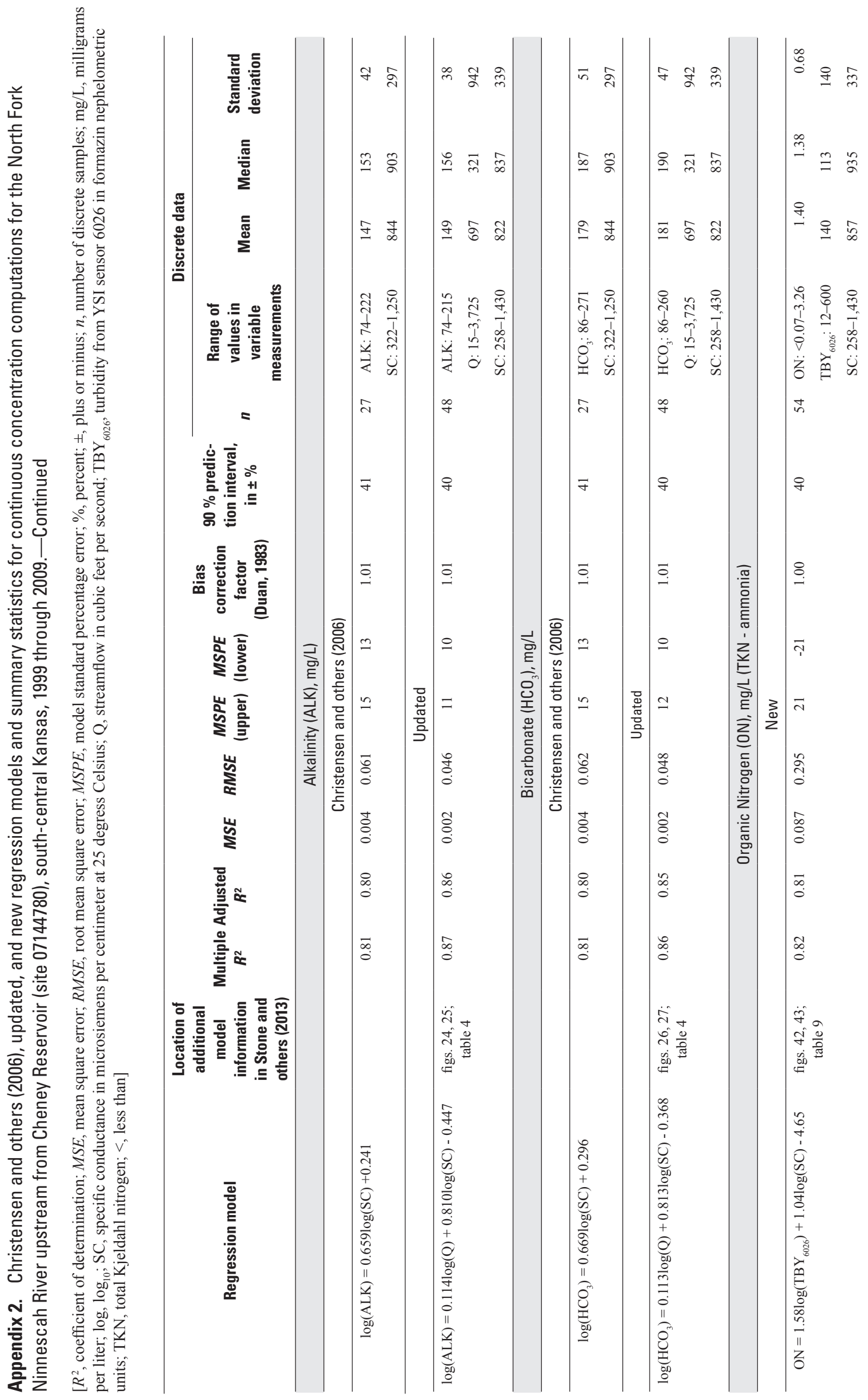




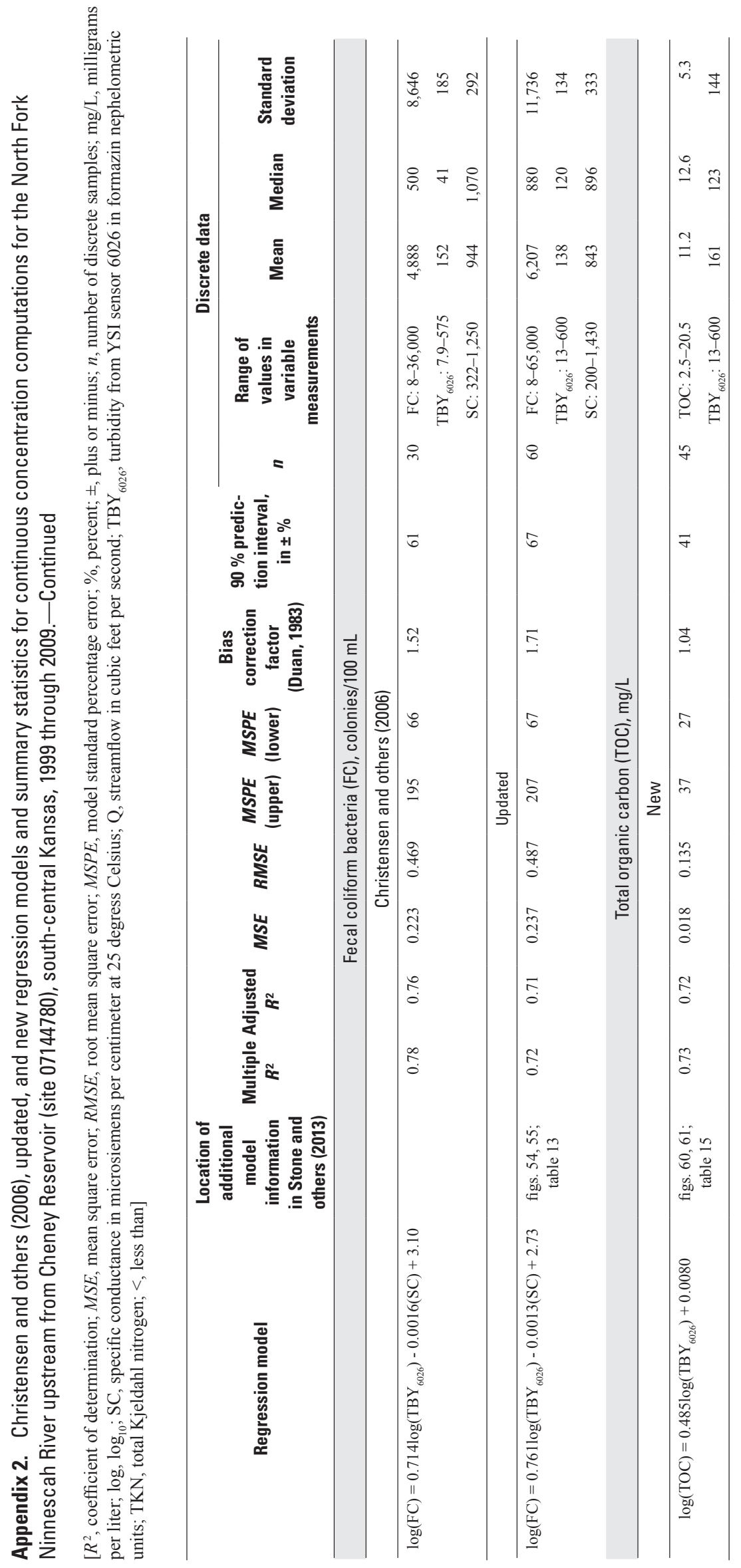




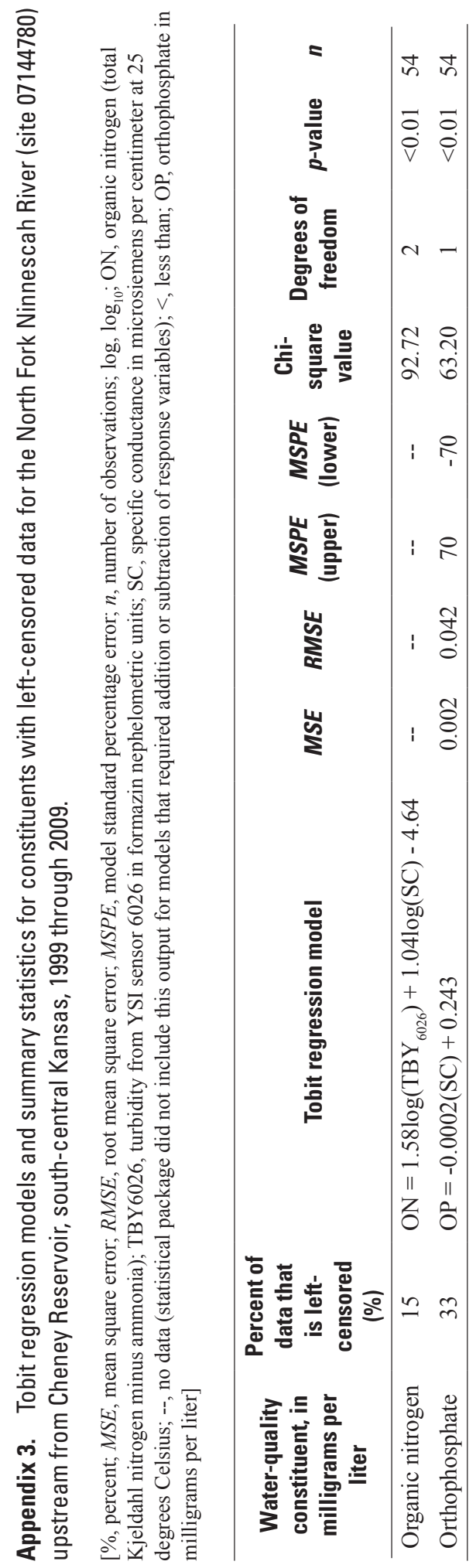


Appendix 4. Summary statistics for data used in turbidity sensor linear regression analyses for the North Fork Ninnescah River upstream from Cheney Reservoir (site 07144780), south-central Kansas, October 1999 through October 2010.

$\left[R^{2}\right.$, coefficient of determination; $n$, number of observations; TBY ${ }_{6136}$, YSI model 6136 turbidity in formazin nephelometric units (FNU); TBY ${ }_{6026}$, YSI model 6026 turbidity in FNU]

\begin{tabular}{|c|c|c|c|c|c|c|}
\hline Regression equation & $R^{2}$ & $\begin{array}{c}\text { Turbidity sensor type } \\
\text { or ratio }\end{array}$ & $n$ & Range & Mean & Median \\
\hline \multirow[t]{3}{*}{$\mathrm{TBY}_{6136}=0.701\left(\mathrm{TBY}_{6026}\right)$} & 0.96 & YSI $_{6026}$ & 7,429 & $4.0-1,570$ & 44 & 28 \\
\hline & & YSI $_{6136}$ & 7,429 & $1.8-1,160$ & 32 & 19 \\
\hline & & $\mathrm{YSI}_{6136} / \mathrm{YSI}_{6026}$ ratio & 7,429 & $0.19-3.92$ & 0.70 & 0.68 \\
\hline
\end{tabular}


Appendix 5. Updated Christensen and others (2006) regression models for the North Fork Ninnescah River upstream from Cheney Reservoir (site 07144780), south-central Kansas.

[mg/L, milligrams per liter; 6026, YSI model 6026 turbidity sensor; $\log , \log 10$; TSS, total suspended solids in milligrams per liter; TBY $_{6026}$, turbidity from YSI sensor 6026 in formazin nephelometric units; 6136, YSI model 6136 turbidity sensor; TBY ${ }_{6136}$ turbidity from YSI sensor 6136 in formazin nephelometric units; SSC, suspended sediment concentration in milligrams per liter; $\mathrm{TKN}$, total Kjeldahl nitrogen (total ammonia plus organic nitrogen) in milligrams per liter; Q, streamflow in cubic feet per second; TP, total phosphorus in milligrams per liter; col/100 mL, colonies per 100 milliliters; FC, fecal coliform bacteria in colonies per 100 milliliters; SC, specific conductance in in microsiemens per centimeter at 25 degrees Celsius]

\begin{tabular}{lcl}
\hline \multicolumn{1}{c}{ Constituent } & $\begin{array}{c}\text { Sensor } \\
\text { type }\end{array}$ & \multicolumn{1}{c}{ Regression model } \\
\hline Total suspended solids $(\mathrm{mg} / \mathrm{L})$ & 6026 & $\log (\mathrm{TSS})=0.893 \log \left(\mathrm{TBY}_{6026}\right)+0.253$ \\
& 6136 & $\log (\mathrm{TSS})=0.893 \log \left(\mathrm{TBY}_{6136}\right)+0.402$ \\
Suspended sediment $(\mathrm{mg} / \mathrm{L})$ & 6026 & $\log (\mathrm{SSC})=1.10 \log \left(\mathrm{TBY}_{6026}\right)+0.0037$ \\
& 6136 & $\log (\mathrm{SSC})=1.10 \log \left(\mathrm{TBY}_{6136}\right)+0.188$ \\
& & \\
Total Kjeldahl nitrogen $(\mathrm{mg} / \mathrm{L})$ & 6026 & $\mathrm{TKN}=0.0054\left(\mathrm{TBY}{ }_{6026}\right)-0.0004(\mathrm{Q})+0.790$ \\
& 6136 & $\mathrm{TKN}=0.0079\left(\mathrm{TBY}{ }_{6136}\right)-0.0004(\mathrm{Q})+0.790$ \\
Total phosphorus $(\mathrm{mg} / \mathrm{L})$ & 6026 & $\mathrm{TP}=0.0008\left(\mathrm{TBY}_{6026}\right)+0.0001(\mathrm{Q})+0.0863$ \\
& 6136 & $\mathrm{TP}=0.0012\left(\mathrm{TBY}_{6136}\right)+0.0001(\mathrm{Q})+0.0863$ \\
& & \\
\hline
\end{tabular}


Appendix 6. Updated new regression models for the North Fork Ninnescah River upstream from Cheney Reservoir (site 07144780), south-central Kansas.

[mg/L, milligrams per liter; 6026, YSI model 6026 turbidity sensor; $\log , \log _{10}$, TSS, total suspended solids in milligrams per liter; TBY 6026 , turbidity from YSI sensor 6026 in formazin nephelometric units; 6136, YSI model 6136 turbidity sensor; TBY ${ }_{6136}$, turbidity from YSI sensor 6136 in formazin nephelometric units; SSC, suspended sediment concentration in milligrams per liter; Q, streamflow in cubic feet per second;TKN, total Kjeldahl nitrogen (ammonia plus organic nitrogen) in milligrams per liter; $\mathrm{NO}_{3}$, nitrate in milligrams per liter; sin, sine; $\mathrm{D}$, day of year; cos, cosine; ON, organic nitrogen (total ammonia plus organic nitrogen minus ammonia); SC, specific conductance in microsiemens per centimeter at 25 degrees Celsius; TN, total nitrogen in milligrams per liter; TP, total phosphorus in milligrams per liter; col/100 mL, colonies per 100 milliliters; EC, Escherichia coli bacteria in colonies per 100 milliliters; FC, fecal coliform bacteria in colonies per 100 milliliters; TOC, total organic carbon in milligrams per liter]

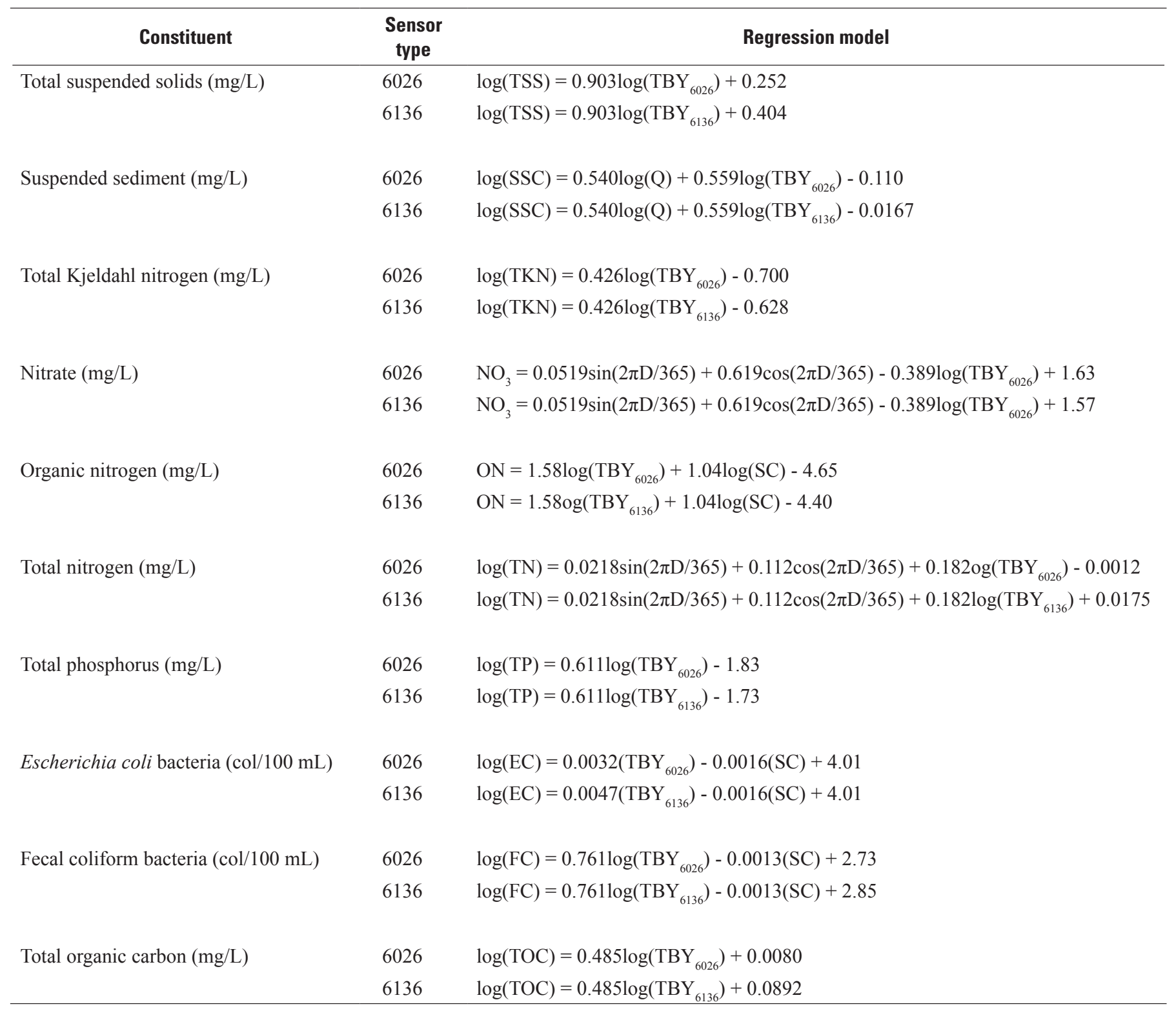


Publishing support provided by:

Rolla Publishing Service Center

For additional information concerning this publication, contact: Director, USGS Kansas Water Science Center 4821 Quail Crest Place

Lawrence, KS 66049

(785) 842-9909

Or visit the Kansas Water Science Center Web site at: http://ks.water.usgs.gov 
